\title{
ARC SAC SCIENTIFIC REVIEW Appropriate water temperatures in which to conduct American Red Cross Aquatic Instructional programs
}

Scientific Advisory Council

\section{Questions to be addressed:}

Water Temperature

- What is the appropriate safe temperature -range for conducting ARC aquatic programs?

- Are safe temperature ranges different for head-in vs head-out immersion activities?

- What variables exist that affect temperature ranges?

- What associated variables should be considered in modifying the suggested range?

\section{Introduction/Overview:}

Water temperature is a major factor in participant comfort and overall success of an American Red Cross Aquatic Instruction programs. Water that is too cold can lead to chilling and discomfort and result in limiting the time spent on necessary practice. The ARC currently references the Aquatic Exercise Association (AEA) guidelines for water temperature stating "a comfortable water temperature for swim classes is between $83^{\circ}$ to $86^{\circ} \mathrm{F}\left(28.3^{\circ}\right.$ to $\left.30^{\circ} \mathrm{C}\right)$ ". These guidelines have recently been revised and updated for 2010 . The current recommendation given for children swim lessons is $84^{\circ} \mathrm{F} / 28.9^{\circ} \mathrm{C}$. The range that is listed as "ideal" for a "Learn to Swim (LTS)" program is from $84-89^{\circ} \mathrm{F}$ or $28.9-31.7^{\circ} \mathrm{C}$. The range of water temperatures recommendation for infant/ pre-school (ages 4 and under) programming is $90-93^{\circ} \mathrm{F}$ or 32.2 $33.9^{\circ} \mathrm{C}$.

The AEA guidelines also include a statement that suggests that these guidelines may not be appropriate for every program. For example, it is an accepted fact that "young children are more susceptible to hypothermia than older children" (ARC p.148). Red Cross recommends that if water and air temperatures cannot be maintained within acceptable ranges, the lesson needs to be shortened. These statements show recognition that there is a direct relationship between water temperature and time / duration of the lesson but there is little guidance beyond these reference statements.

In addition to age of the participant and duration of the lesson, temperature ranges may also need to be adjusted based on the type of programming. What this means for American Red Cross LTS programs is what levels are being offered and will participants be able maintain a level of activity that will support thermoregulation. Keeping participants active or active enough to stay warm is not always possible with every level. Limitations might include the size of the practice area, children who do not possess enough skill to keep moving or classes that are so large that participants stand around waiting for a turn. Any of these scenarios may require an adjustment to the water temperature recommendations. 
And then there are programs that truly operate outside the norm for LTS programs ("norm" meaning the program structure currently recommended in the Water Safety Instructor Manual). Therefore, it is the purpose of this review to confirm the recommended temperature ranges provided by AEA and USA Swimming, to identify significant variables that affect thermoregulation and to provide more guidance where temperature extremes are the norm or program types and structure vary widely.

\section{Review Process and Literature Search Performed}

Pubmed search, Google scholar

Pubmed searched for studies using variations of the following concepts: cold water immersion, thermoregulation, thermal balance, immersion hypothermia, temperature regulation, swimming and water temperature

We found 116 articles and rejected 41 of these as not relevant to the question.

2010 USA Swimming Rules and Regulations (rule 103.6)

American Red Cross Water Safety Instructor Manual

Aquatic Exercise Association (AEA) 2010 Standards and Guidelines Aquatic Fitness Programming

\section{Review of bibliography of selected manuscripts}

\section{Criteria for considering studies for this review}

Only human studies (no mechanical models)

Swimming research with reference to water temperature and intensity of exercise Immersion to at least the middle of the sternum (head-in full immersion preferred but not required)

Definitions relevant to the discussion; (from Bligh J, and Johnson KG. Glossary of terms for thermal physiology. Journal of Applied Physiology 1973; 35(6): 941-961)

ACCLIMATION: A physiological change, occurring within the lifetime of an organism, which reduces the strain caused by experimentally induced stressful changes in particular climatic factors.

ACCLIMATIZATION: A physiological change, occurring within the lifetime of an organism, which reduces the strain caused by stressful changes in the natural climate. 
AREA TOTAL BODY $(\mathrm{A} \rho)$ : The area of the outer surface of the body assumed smooth. $\left[\mathrm{m}^{2}\right]$

BODY HEAT BALANCE: The steady-state relation in which heat production in the body equals heat loss to the environment.

CRITICAL TEMPERATURE, LOWER: The ambient temperature below which the rate of metabolic heat production of a resting thermoregulating animal increases by shivering and or nonshivering thermogenic processes to maintain thermal balance. CRITICAL WATER TEMPERATURE (TCw): the lowest water temperature in which a human subject can be immersed to the neck for a period 3 hours without shivering.

FEVER: A pathological condition in which there is an abnormal rise in core temperature (Tc). The temperature rise in an individual may be considered as fever when it is greater than the mean $\mathrm{SD}$ for the species in basal condition.

HABITUATION: Reduction of responses to or perception of repeated stimulation.

HEAT STORAGE, CHANGE IN: The gain or loss of heat associated with change in body temperature or body mass.

HOMEOTHERMY: The pattern of temperature regulation in a TACHYMETABOLIC species in which the cyclic variation in core temperature, either nychthermally or seasonally, is maintained within arbitrarily defined limits $\left( \pm 2^{\circ} \mathrm{C}\right)$ despite much larger variations in ambient temperature.

HYPOTHERMIA: The condition of a temperature regulating animal when the core temperature is more than one standard deviation (1 SD) below the mean core temperature of the species in resting conditions in a thermoneutral environment.

MET: an assigned unit of measurement to designate "sitting-resting" metabolic rate of man. 1 met $=58.15 \mathrm{~W} \cdot \mathrm{m}^{-2}=50 \mathrm{kcal} \cdot \mathrm{h}^{-1} \cdot \mathrm{m}^{-2}$

It is an empirical unit of measurement to express the metabolic rate of a man whose clothing has an insulative value of $1 \mathrm{CLO}$ when he is sitting at rest, in comfortable indoor surroundings $\left(21^{\circ} \mathrm{C}\right)$.

METABOLIC FREE ENERGY PRODUCTION (M): The rate of transformation of chemical energy into heat and mechanical work by aerobic and anaerobic metabolic activities within an organism, usually expressed in terms of unit area of the total body surface area.

METABOLIC HEAT PRODUCTION $(H)$ : Rate of transformation of chemical energy into heat in an organism, usually expressed in terms of unit area of the total body surface.

METABOLIC RATE (MR): see $M$. MR may also be given as the total free energy production in the organism in unit time [W] or as the free energy production per unit mass of tissue in unit time $\left[\mathrm{W} \cdot \mathrm{kg}^{-1}\right]$. 
METABOLISM: is a general term which relates to chemical and physical changes occurring in living organisms. In thermal physiology METABOLISM invariably relates to the transformation of chemical energy into free energy ...

TEMPERATURE, AMBIENT (Ta): The average temperature of a gaseous or liquid environment (usually air or water) surrounding a body, as measured outside the thermal and hydrodynamic boundary layers that overlay the body $\left[{ }^{\circ} \mathrm{C}\right]$.

TEMPERATURE, CORE (Tc): The mean temperature of the tissues at a depth below that which is affected directly by a changing the temperature gradient through peripheral tissues. Mean core temperature cannot be measured accurately, and is generally represented by a specified core temperature, e.g., that of the rectum $\left(\right.$ Tre) $\left[{ }^{\circ} \mathrm{C}\right]$.

TEMPERATURE, MEAN BODY (Tb): The sum of the products of the heat capacity and temperature of all the tissues of the body divided by the total heat capacity of the organism.

Note: This heat capacity cannot be determined precisely in the living organism. Mean body temperature can be estimated approximately from measures of skin (mean skin temperature; Tsk) and core temperature.

TEMPERATURE REGULATION: The maintenance of the temperature or temperatures of a body within a restricted range under conditions involving variable internal and /or external heat loads.

TEMPERATURE REGULATION, BEHAVIORAL: The regulation of body temperature by complex patterns of responses of the skeletal musculature to heat and cold which modify the rates of heat production and/or heat loss (e.g., by exercise, change in body conformation, and in the thermal insulation of bedding and (in man) of clothing, and by the selection of an environment that reduces thermal stress).

THERMAL COMFORT: Subjective satisfaction with the thermal environment.

THERMAL CONDUCTANCE, TISSUE: The rate of heat transfer per unit area during steady state when temperature difference of $1{ }^{\circ} \mathrm{C}$ is maintained across the tissue.

Note: this term relates to heat transfer down a temperature gradient from any tissue to its immediate environments, e.g., from a tissue to circulating blood as well as from the body core through peripheral tissues of the body surface.

THERMAL CONDUCTIVITY (k): A property of the material defined by the flow of heat by conduction through unit thickness of the material per unit area and per unit temperature difference maintained at right angles to the direction of heat flow.

THERMAL STRESS: Any change in the thermal relation between an organism and its environment which, if uncompensated by a temperature-regulatory response, would disturb the thermal equilibrium. 
THERMOGENISIS, SHIVERING: An increase in the rate of heat production during cold exposure due to increased contractile activity of skeletal muscles not involving voluntary movements and external work.

THERMALNEUTRAL ZONE (TNZ): The range of ambient temperature within which metabolic rate is at a minimum, and within which temperature regulation is achieved by nonevaporative physical process alone $\left[{ }^{\circ} \mathrm{C}\right]$

\section{$\underline{\text { Scientific Foundation: }}$}

Much research has been done on immersion hypothermia, survival rates and safety measures. These will not be reiterated in this work.

\section{Thermoregulation}

Human beings, as all warm blooded animals, maintain core temperatures (Tre or Tc) within a very narrow range. The average core temperature of a human is around $37^{\circ} \mathrm{C}\left(98.6^{\circ} \mathrm{F}\right)$ and body temperature extremes are demonstrated as a fever at $37.7^{\circ} \mathrm{C}\left(100^{\circ} \mathrm{F}\right)$ and when the mean body temperature falls to approximately $35.4^{\circ} \mathrm{C}\left(95.7^{\circ} \mathrm{F}\right)(20)$ just slightly more than $2^{\circ} \mathrm{C}$. Therefore, our ability to regulate body temperature is critical for life safety and comfort.

Thermoregulation depends on the dynamic balance between heat gained (or generated) and heat lost to the environment. When a thermal stress is imposed on a human body, it reacts with a combination of metabolic and cardiovascular adjustments to maintain thermal comfort. The basic patterns of cold regulation include heat production by shivering and vasomotor responses which transfer heat down a thermal gradient from core to skin and then from skin to the environment. Vasoconstriction is a cold defense reaction that helps conserve heat by restricting blood flow to the periphery. When peripheral responses have been maximized, humans must either add insulation or rely on their ability to increase metabolism.

General responses to cold stress, whether in air or water, are similar in nature. However, resistance to the flow of heat energy is lower in the water as compared to air and becomes much lower when the skin and/or water are in motion. This makes temperature regulation during immersion more challenging than in air $(29,45,47,48)$.

The most comfortable temperature for a person at rest is referred to as "thermoneutral". This is the temperature at which unprotected man, at rest, will neither lose nor gain heat.

Thermoneutrality in air is around $22.2^{\circ} \mathrm{C}\left(72^{\circ} \mathrm{F}\right)(19)$. An equivalent water temperature would be around $33^{\circ} \mathrm{C}\left(91.4^{\circ} \mathrm{F}\right)$. Cannon and Keatinge (1960) call this the "theoretical critical temperature", where man "could, in theory achieve thermal stability without an increase in metabolic rate ..." (p. 338). Craig and Dvorak (1966) suggest that a neutral water temperature, (demonstrated by a mean body temperature that is the same at the beginning of an hour of immersion as at its conclusion) would have to be $34.6^{\circ} \mathrm{C}$ (94.2). Sagawa et al. (1988) confirm these findings. They reported thermoneutral for their subjects as a water temperature of $34^{\circ} \mathrm{C}$.

\section{Comparing Research}


Research involving human response to cold immersion is plentiful and in general seeks to establish different critical temperatures using a variety protocols. However, because direct measurement of the hypothalamic temperature is not possible, other interactions must be used (6). The selection of measurements and the variety of combinations makes it difficult to compare results. The most common temperature measurements include core temperature (rectal temperature and sometimes esophageal temperatures in adults), esophageal and tympanic temperature (in younger adults and children), skin temperature, mean body temperature, subcutaneous fat thickness, surface area to mass ratio and a variety of metabolic responses including $\mathrm{VO}_{2 \max }$ and metabolic rate.

Comparing research is further complicated because of differences in methodology. Studies differ with the temperature of the water, duration of exposure, depth of immersion (head-out, head-in, chest deep, to the first thoracic vertebrae), body position (vertical, semi recumbent, horizontal) and type of and intensity of exercise (assuming that an exercise protocol is used). It is therefore prudent to proceed with caution when trying to compare results.

The most common water temperatures used to study an unprotected subject at rest during headout immersion include $15^{\circ} \mathrm{C}(9,35,36,41,71,72), 18^{\circ} \mathrm{C}(4,16,24,25,63), 20^{\circ} \mathrm{C}(8,9,23,38$, $42,43,71,72), 25^{\circ} \mathrm{C}(8,9,32,36,39,41,69), 26^{\circ} \mathrm{C}(12,16,24,65), 28^{\circ} \mathrm{C}(12,39,42,43,62$, $71,72)$. From these studies, certain general statements can be made. The following are general responses to water immersion in temperatures ranging from $15^{\circ} \mathrm{C}$ to $33^{\circ} \mathrm{C}$ :

1) There is a direct relationship between water temperature (Tw) and the length of time a person can be comfortably immersed. $(7,12,26,34,37,39,53,65,75)$ (As would be expected, when water temperature decreases, the duration of comfortable immersion also decreases.)

2) Metabolic rate increases as the temperature of the water decreases $(7,8,16,24,32,57$, 62). (Shivering is similar to light exercise which increases the metabolic rate).

3) The range of water temperatures in which man can attain thermal balance can be extended by reducing the total surface area exposed to the water, by exercise $(9,13,32$, $36,43,44,50,57,65)$ and by adding clothing $(10,22,29,34,36,51,52,73)$.

4) Head submersion increases the cooling rate of the body $(22,28,39,52,62,69)$.

5) If water temperature and duration of immersion are controlled, there are a number of factors that act in concert to extend or reduce thermal comfort. These include but may not be limited to; surface area to mass ratio(14, 25, 26, 28, 38, 39, 44, 59 61, 63), subcutaneous fat thickness $(3,4,7,8,9,16,24,25,28,34,35,38,42,44,49,53,54,59$, $60,62,64,65,69)$, age $(10,15,18,23,40,59,62,63,71,72,73)$, gender $(28,37,39,40$, $42,43,55,59,63,71)$, rest v exercise $(9,26,28,32,41,45,49,65)$, level of fitness $(15$, $34,40)$, and possibly acclimation (55) 
6) The type and intensity of exercise in the water affects the cooling rate of the body. (walking, cycling, rowing, swimming, arm ergometer are examples that appear in these protocols) $(9,11,13,20,26,28,29,36,41,47,58,67)$.

7) The ability of the arms to retain heat is lower than that of the legs due to the higher surface area to mass ratio. Arms have approximately two times the SA/mass ratio as the legs. $(9,26,64,67)$ (The majority of recognized swim strokes require higher levels of work from arms than legs even at similar workloads. (26, p404).

8) There is a direct, nonlinear relationship between percent body fat (\%BF) and critical water temperature (Tcw) (Persons with greater \% BF have a lower Tcw and therefore can remain longer in the water with less cold stress)( $3,4,7,8,9,16,24,25,28,34,35$, $38,42,44,49,53,59,60,62,64,65)$

9) Performance is affected by water temperature extremes. $(46,47,50,64)$

It is apparent from these studies that certain temperatures are well outside the range of comfort and therefore inappropriate for swimming instruction. Thus it becomes necessary to find a narrower range for thermal comfort. This can be accomplished by first looking at water temperatures that illicit little or no cold stress responses (head-out, at rest) and work to identify a range of temperatures appropriate for swimming (head- in) and learning to swim at different levels of intensity and for durations appropriate for LTS programming.

\section{The Lower Limits of Thermal Comfort}

A number of studies have used a three hour immersion (head-out) protocol to established "critical water temperature (Tcw)", defined as the lowest water temperature that an unprotected subject can tolerate at rest without shivering. Sagawa et al. (1988) studied 6 men immersed to the neck (\%BF not given) and found Tcw to be $31.2 \pm 0.5^{\circ} \mathrm{C}$. Ferretti et al. (1988) also used a 3 hour immersion protocol to establish an individuals' Tcw and then used Tcw $-6^{\circ} \mathrm{C}$ to study the effect of exercise (head out immersion) on thermoregulation. Park et al. (1984) established Tcw for their subjects at between $28-32^{\circ} \mathrm{C}$ before looking at body insulation as it relates to exercise in cool water. Iwamoto et al. (1988) used a 2 hour protocol to establish Tcw. Critical water temperature was established at $32 \pm 0.4^{\circ} \mathrm{C}$ for 9 healthy men with $15.3 \pm 1.2 \% \mathrm{BF}$. Bullard and Rapp (1970) suggest that the average Tcw is around $33^{\circ} \mathrm{C}$. Cannon and Keatinge (1960) tested men immersed head-out, at rest in increasingly colder water until Tre fell steadily after 2.5 hours and found that metabolic rates increased in water lower than $33^{\circ} \mathrm{C}$.

Most LTS programs have a 30 -45 minute class time limit, so a 2-3 hour immersion study may not seem relevant to our discussion. However, the importance lies in considering that instructors may be teaching back to back lessons without re-warming. Studies whose protocols involve shorter (60 minutes or less) durations will have more relevance in establishing guidelines for participants. Carlson et al. (1958) who found that men immersed to the neck for 60 minutes began shivering when water temperatures dropped $2-3^{\circ} \mathrm{C}$ below control $\left(33^{\circ} \mathrm{C}\right)$. Craig and Dvorak (1966) studied men immersed head-out, at rest and found that when water temperatures were below $35^{\circ} \mathrm{C}$ for a duration of 60 minutes, Tre was lower than for control values. Strong et 
al. (1985) found that males immersed horizontally at rest in water at $35^{\circ} \mathrm{C}$ and $32^{\circ} \mathrm{C}$ for 1 hour at a time showed similar metabolic responses when compared to pre-immersion values. These studies support recommending water temperatures for inactive adults with wide variations in $\% \mathrm{BF}$ and surface area to mass ratio who are immersed to the neck for an hour in the range of 28 $-35^{\circ} \mathrm{C}$.

Again, these temperatures represent a range for inactive, head-out adults but the true challenge of thermoregulation in the water is when the body is fully immersed (submersion) as in swimming, free diving or SCUBA diving. Head submersion increases the cooling rate of the body $(22,51$, 52). Pretorius et al. (2006) studied 8 male subjects in $\mathrm{Tw}$ at $17^{\circ} \mathrm{C}$ under four separate conditions; 1)head- out body insulated, 2)head-out, body not insulated, 3)head submerged, body insulated and 4)head submerged, body not insulated. They found that the head which accounts for only $7 \%$ of the surface area of the body contributed only $10 \%$ of the total body heat loss. However, head submersion increased the cooling rate by an average of $42 \%$. Giesbrecht et al. (2005) reported an increase in body cooling by as much as $40 \%$ with head submersion as compared to head-out immersion.

It would seem intuitive that for swimming, thermal comfort may require a higher range of temperatures. However, previous studies have confirmed that a number of factors influence heat loss during immersion. The most significant of these are subcutaneous fat thickness, surface area to mass ratio and immersion at rest versus with exercise, with particular respect to exercise intensity. Therefore, it is important to consider the influence of these factors before establishing guidelines for swimming programs.

\section{The role of subcutaneous fat and surface area to mass ratio}

Numerous studies have demonstrated the role of subcutaneous fat thickness in managing cold stress. $(3,4,7,35,42,47,54,59)$ Body fat has a low thermal conductivity and therefore helps retain body heat (38). Individuals with low $\% \mathrm{BF}$ cool more quickly than those with high $\% \mathrm{BF}$ when immersed in cool / cold water. Cannon and Keatinge (1960) found that thin men had a steeper rise in MR (an indication of shivering) than fat men. Wade et al. (1979) reported on men immersed at rest lying on a cot in water at $25.2^{\circ} \mathrm{C}$ and found a significant correlation between heat flow from the head, neck and torso and subcutaneous fat thickness. Smith and Hanna (1975) determined that the range of Tcw $\left(29-31^{\circ} \mathrm{C}\right)$ for 14 male subjects was a result of the differences in subcutaneous fat thickness.

Although subcutaneous fat provides significant insulation, body size, (surface area to mass ratio) has also been found to contribute to body heat loss $(17,38,41,49,54,62,65)$. Beckman and Reeves (1966) showed that the rate of heat loss is a function of the amount of surface area exposed to the water and the relative thermal conductivity of that area. Strong et al. (1985) found that small individuals demonstrate a greater increase in tissue insulation and metabolic heat production per decrease in Tre and Tsk than large individuals. This holds true for the amount of surface area exposed to the water as well as the surface area to mass ratio of the extremities. Sagawa et al. (1988) reported that resting heat loss was greater in the limbs than the trunk. Lee et al. (1997) studied men immersed at knee, hip and shoulder levels and found that thermal balance in shoulder level water was not possible in water at 15 or $25^{\circ} \mathrm{C}$. 


\section{The role of exercise}

There is little doubt that at certain temperatures exercise contributes to thermoregulation (13, 26, $32,36,43,44,50,57)$. When a person begins exercising in the water, heat from the working muscles helps maintain thermal balance. To what degree depends not only on the temperature of the water, but to a great degree on the type of exercise and the intensity of the effort (determine as a percentage of $\left.\mathrm{VO}_{2 \max }\right)$.

There is an inverse relationship between water temperature and the intensity of exercise needed to attain / maintain thermal balance. In general, the colder the water (to a point), the higher the intensity needed to maintain thermal equilibrium $(13,32,43,44,58,66,67)$. However, there are also temperatures below which no amount of exercise can keep the core temperature from dropping $(26,27,32,41)$.

Exercise intensity can be expressed in a number of ways, as a percentage of $\mathrm{VO}_{2 \max }$, in energy equivalents such as METs (metabolic equivalents), milliliters per kilogram per minute, liters per minute, kcal per kilogram per hour and kcal per minutes. Each of these is based on a persons' body weight and therefore difficult to compare from study to study. For the purpose of this discussion we will identify each effort as light, moderate and hard work to simplify comparison when possible.

With light exercise, the range of comfortable temperatures for head out immersion seems to vary between 26 and $32^{\circ} \mathrm{C}$. Lee et al. (1997) found that light exercise (leg cycling at $35 \% \mathrm{VO}_{2 \max }$ ) did not maintain Tre in shoulder depth water at $25^{\circ} \mathrm{C}$. Choi et al. (1996) studied subjects on a bicycle ergometry at MR corresponding with $60 \mathrm{kcal} \cdot \mathrm{h}^{-1} \cdot \mathrm{m}^{-2}$ (very light workload). For most subjects in this study, Tre declined in water below $30^{\circ} \mathrm{C}$ whether during rest or exercise. Craig and Dvorak (1968) reported that during light (.70 1/min) leg work, Tre continued to decline when water was less than $32^{\circ} \mathrm{C}$. Pirnay et al. (1997) reported that subjects in their study were able to maintain thermal balance with light and moderate exercise in $26^{\circ} \mathrm{C}$. With moderate workloads, it seems that most adults can maintain thermal equilibrium at approximately $25^{\circ} \mathrm{C}$ for efforts of 30 to 60 minutes $(32,44,58)$

The type of exercise performed in the water is also a variable in thermoregulation. The types of exercises representative of the "head-out" immersion studies include arm exercise such as rowing, or arm cycle ergometry $(66,67)$, leg exercise, the most common of which is a cycle ergometry $(9,13,26,32,41,44,50,65)$ and a combination of leg and arm exercise $(28,43,49$, 67). It seems that leg exercise results in a smaller fall of Tre with cold immersion or maintains thermal balance when compared to arm exercise at the same level of effort $(26,49,66,67)$.

Efficient swimming requires head submersion and a greater use of the arms. Wade and Veghte (1977) used radiograms to study heat loss areas in swimming subjects in $23^{\circ} \mathrm{C}$ water. The warmest areas recorded for the non immersion control were in the chest, groin, lower abdomen and neck. After a 500 yard freestyle swim, the warmest areas were the trapezius, deltoids, triceps, biceps brachii and the pectorals (the active swimming muscles). The legs, however, remained cooler. Considering that swimming is a predominantly upper body exercise, it would 
seem intuitive that temperature ranges for efficient swimming might be somewhat higher especially when compared to ranges for leg dominant, head-out, water exercise protocols.

In swimming (freestyle and breaststroke) research, the most common temperatures in literature are $18^{\circ} \mathrm{C}(30,47,64), 21^{\circ} \mathrm{C}(21,31,54,56), 25^{\circ} \mathrm{C}(39,54,64,74), 26^{\circ} \mathrm{C}(11,30,46,47)$ and $33^{\circ} \mathrm{C}(20,21,31,48,56,75)$. These temperatures have been studied to establish the range for competitive swimming and /or to identify a range of temperatures that affect swimming performance. As would be expected from previously reviewed immersion literature and with all things being equal (surface area to mass ratio, subcutaneous fat thickness and duration of immersion) temperature ranges for swimming are dependent on swimming intensity $(30,31,47)$.

Fujishima et al. (2001) looked at thermoregulatory responses to prolonged (120 minutes) breaststroke in 23,28 and $33^{\circ} \mathrm{C}$. Subjects swam at $50 \% \mathrm{VO} 2 \mathrm{max}$ in $23^{\circ} \mathrm{C}$ water, $43 \% \mathrm{VO} 2 \mathrm{max}$ in $28^{\circ} \mathrm{C}$ water and at $42 \% \mathrm{VO} 2 \mathrm{max}$ in $33^{\circ} \mathrm{C}$. Tres declined in both 23 and $28^{\circ} \mathrm{C}$ and increased in $33^{\circ} \mathrm{C}$ water. Robinson and Somers (1971) looked at swimmers swimming freestyle for 60 minutes in water 21,29 and $33^{\circ} \mathrm{C}$. They reported that in $21^{\circ} \mathrm{C}$ the Tre of the slowest swimmers declined and the average Tre of the fastest swimmers increased slightly. They suggested that optimal water temperature for swimmers was nearer $29^{\circ} \mathrm{C}$ because at that temperature core and surface temperature gradients were adequate for heat conductance. The findings of Nadal et al. (1974) agree. They suggest that the optimal water temperature for sprint performance is between 28 and $30^{\circ} \mathrm{C}$.

Houston et al. (1978) studied male subjects swimming breaststroke for an hour at 65\% VO2max in 21,27 , and $33^{\circ} \mathrm{C}$. Core and esophageal temperatures tended to rise in $27^{\circ} \mathrm{C}$ and decreased by a similar magnitude in $21^{\circ} \mathrm{C}$. They suggested that competitive swimmers might benefit from the thermal stress presented by $21^{\circ} \mathrm{C}$ but that recreational swimmers might need at least $27^{\circ} \mathrm{C}$ to maintain thermal equilibrium. Galbo et al. (1979) confirms these findings. Subjects in this study reported that it was more difficult to swim in 21 and $33^{\circ} \mathrm{C}$ as compared to $27^{\circ} \mathrm{C}$ water. In Holmer and Bergh (1974) subjects swam breaststroke in three different water temperatures (18, 26 and $34^{\circ} \mathrm{C}$ ) with two different intensities. They performed a 20 minute submaximal (approximately 50\% $\mathrm{VO}_{2 \max }$ ) effort for 20 minutes and then a maximal test in each water temperature. For all maximal efforts Tes rose exponentially. Tes was lower for both 18 and $26^{\circ} \mathrm{C}$ with submaximal effort for 20 minutes.

It would appear that water temperature for thermal comfort during light to moderate swimming intensities can range from $27-32^{\circ} \mathrm{C}$. For maximal efforts that range can vary from $18-30^{\circ} \mathrm{C}$. Keep in mind that these studies were done with adult subjects. These ranges will need to be adjusted based on age and possibly gender.

\section{Gender and age}

Adjustments to cold exposure have been found to differ with age and gender $(10,15,18,40,43$, $59,61,71,72)$. Though reasons for this cannot totally be explained, it is clear that children and older adults chill faster than young and middle aged adults and males chill faster than females. Falk (1998) suggests that physical and physiological differences may explain some of the age related adjustments to cold exposure. The two most significant physical differences are surface 
area to mass ratio and $\% \mathrm{BF}$. Children have a higher surface area to mass ratio than adults which increases heat loss. In many instances, young to middle aged adults have a higher $\%$ body fat. Both of these physical factors have been shown to increase the cooling rate of children over adults $(59,61,71)$.

When comparing young adults (18-30) to older adults (50-72), physiology seems to play a greater role than the physical factors. Falk et al. (1994) compared young adults to trained and untrained seniors at Ta thermoneutral $\left(22^{\circ} \mathrm{C}\right)$ and Ta $5^{\circ} \mathrm{C}$ for 30 minutes at rest and 30 minutes of exercise. Young adults were able to maintain Tre with low intensity exercise, trained and untrained seniors were not. Collins et al. (1985) found that older adults had a significantly greater increase in blood pressures at $\mathrm{Ta} 6^{\circ} \mathrm{C}$ than younger adults. LeBlanc et al. (1978) found a significant relationship between $\mathrm{VO}_{2 \max }$ and a fall in skin temperature. They found that subjects with lower $\mathrm{VO}_{2 \max }$ experienced a larger drop in Tsk. Maximal aerobic power decreases with age and a lower $\mathrm{VO}_{2 \max }$ could account for some of the age related differences in cold stress responses. Frank et al. (2000) supports this hypothesis.

\section{The Upper Limits of Thermal Comfort}

There are warm water temperature limits for thermal comfort as well. Veicsteinas et al. (1982) found that vasodilation (heat dissipation) occurred at water temperatures between $32-33^{\circ} \mathrm{C}$ in men immersed head-out at rest for 3 hours. Craig and Dvorak (1966) reported that when water temperature was 36 or $37^{\circ} \mathrm{C}$, men showed a continuous increase in the central temperature. Tre also increased with a high work load in $28-32^{\circ} \mathrm{C}$ water. Participants in this study reported feeling most comfortable in $34-36^{\circ} \mathrm{C}$ and feeling tired and restless at $37^{\circ} \mathrm{C}$.

Shimizu et al. (1998) found that Tre rose significantly at $29^{\circ} \mathrm{C}$ with exercise at $50 \% \mathrm{VO} 2$ max. Pirnay (1997) also found that sub max levels of exercise (approximately 50\% effort) caused hyperthermia in water $\geq 30^{\circ} \mathrm{C}$. Costill's (1967) findings (20 minutes of submaximal swimming) suggest that if a person is immersed in water below $32^{\circ} \mathrm{C}$ he/she will become hypothermic at a rate proportional to the duration of immersion or the difference in the thermal gradient below $32^{\circ} \mathrm{C}$.

It would seem appropriate than to have temperature ranges for Aquatic Instructional programs adjusted based on activity level and age of the participant. Younger children and older adults need warmer water for thermal comfort and balance. The lower the intensity of the effort, the higher will be the accepted ranges. Participants learning to swim (low intensity or limited activity) need warmer water than more proficient swimmers, participating at a higher level of intensity. The duration of the lesson will have to be based on the other parameters and also be related to current thoughts about learning theory.

\section{Summary:}

In summary, the weight of the evidence suggests that for each person there is a water temperature range in which he/she is most comfortable at rest and at different levels of exercise 
intensity. The number of possible interactions (age, gender, subcutaneous fat thickness, surface area to mass ratio) makes it nearly impossible to set a specific standard for each person / activity in the water and, therefore, only general guidelines will be given.

Based on 9 LOE 2a studies, the recommended water temperature range for adults ages 17-55 immersed with head out of water, at rest, in an indoor pool with controlled humidity and air temperatures for durations ranging from $40-120$ minutes is $29-33^{\circ} \mathrm{C}(84.2-91.4 \mathrm{~F})$. Adults with either higher subcutaneous fat levels or surface area to mass ratio or both, will tolerate water at the lower end of the range for longer periods of time.

Based on 11 LOE $2 \mathrm{a}$ studies, the recommended water temperature range for adults ages 17-55 in an indoor pool with controlled humidity and air temperatures for durations ranging from $20-$ 120 minutes of swimming at low intensities is $29^{\circ}-32^{\circ} \mathrm{C}\left(84.2^{\circ}-89.6^{\circ} \mathrm{F}\right)$. Adults with either higher subcutaneous fat levels or surface area to mass ratio or both, will tolerate water at the lower end of the range for longer periods of time.

Based on 11 LOE 2a studies, the recommended water temperature range for adults ages 17-55 in an indoor pool with controlled humidity and air temperatures for durations ranging from $20-$ 120 minutes and swimming at moderate (at least $50 \%$ effort) to high intensities is $26^{\circ}-28^{\circ} \mathrm{C}$ $\left(78.8^{\circ}-82^{\circ} \mathrm{F}\right)$. Adults with either higher subcutaneous fat levels or surface area to mass ratio or both, will tolerate water at the lower end of the range for longer periods of time

Based on 11 LOE 2a studies, the recommended water temperature range for adults ages 17-55 in an indoor pool with controlled humidity and air temperatures for durations ranging from $15-$ 135 minutes head out exercise at low to moderate intensities is $26^{\circ}-28^{\circ} \mathrm{C}\left(78.8^{\circ}-82^{\circ} \mathrm{F}\right)$. Adults with either higher subcutaneous fat levels or surface area to mass ratio or both, will tolerate water at the lower end of the range for longer periods of time

Based on 31 LOE 2 a studies, the recommended maximum water temperature range for adults ages 17-55 in an indoor pool with controlled humidity and air temperatures for durations ranging from $15-135$ minutes at rest or with low intensity exercise is $\leq 32^{\circ} \mathrm{C}\left(89.6^{\circ} \mathrm{F}\right)$. Adults with either higher subcutaneous fat levels or surface area to mass ratio or both, may not tolerate water at $32^{\circ} \mathrm{C}\left(89.6^{\circ} \mathrm{F}\right)$ for long periods of time. Watch for signs of hyperthermia. (For moderate (at least $\left.50 \% \mathrm{VO}_{2 \max }\right)$ or higher intensities water temperature should not exceed $27^{\circ} \mathrm{C}\left(80.6^{\circ} \mathrm{F}\right)$ 


\section{Overall Recommendation:}

Water temperature is a major factor in participant comfort and overall success of any "Aquatic Instructional" program. Water that is too cold can lead to chilling and discomfort and result in limiting the time spent on necessary practice. Likewise, water too hot can lead to overheating and discomfort in limiting the time spent on necessary practice. In summary, the weight of the evidence suggests that for each person there is a water temperature range in which he/she is most comfortable at rest and at different levels of exercise intensity. The number of possible interactions (age, gender, subcutaneous fat thickness, surface area to mass ratio) makes it nearly impossible to set a specific standard for each person / activity in the water and, therefore, only general guidelines will be given. The most important factor is that Aquatic Instructors are able to recognize when a student needs to end an in or out water session because the early onset of temperature related issues regardless of water temperature.

\section{Recommendations and Strength:}

Standards: None

\section{Guidelines:}

Based on 31 LOE 2a, 4 LOE 2aE studies and 2 LOE 5 studies, in a controlled environment (defined as an indoor pool with controlled humidity and air temperature), and with most of the consideration given to the level of intensity of the activity (as the activity intensity increases thermal balance can be achieved at the lower end of the range) and the immersion time (as immersion time increases core temperature decreases)

Infant / preschool aquatics (20 to 30 minutes*)

Water temperature - water temperature should be $\geq 32^{\circ} \mathrm{C}\left(89.6^{\circ} \mathrm{F}\right)$

Learn to swim up to ages 6- 15 (30 to 45 minutes*)

Water temperature - water temperature should be $\geq 29^{\circ} \mathrm{C}\left(84.2^{\circ} \mathrm{F}\right)$

Junior Lifeguard ages 11-14 (45 to 60 minutes*)

Water temperature water temperature should be $\geq 29^{\circ} \mathrm{C}\left(84.2^{\circ} \mathrm{F}\right)$

Lifeguard training up to ages 15 - 55 (60 to 120 minutes*)

Low intensity activity-water temperature should be $29^{\circ}$ to $32^{\circ} \mathrm{C}\left(84.2^{\circ}\right.$ to $\left.89.6 \mathrm{~F}\right)$ Intense activity - water temperature should be $26^{\circ}$ to $28^{\circ} \mathrm{C}\left(78.8^{\circ}\right.$ to $\left.82^{\circ} \mathrm{F}\right)$

Water Safety Instructor up to ages16- 55 (60 - 120 minutes*)

Low intensity activity-water temperature should be $29^{\circ}$ to $32^{\circ} \mathrm{C}\left(84.2^{\circ}\right.$ to $\left.89.6^{\circ} \mathrm{F}\right)$ Intense activity - water temperature should be $26^{\circ}$ to $28^{\circ} \mathrm{C}\left(78.8^{\circ}\right.$ to $\left.82^{\circ} \mathrm{F}\right)$

* Student immersion time per session. 


\section{Options:}

Instructors should watch for signs of hypothermia or hyperthermia as an indication that it is time to end the session. For water temperatures below the recommended ranges the following options are suggested:

1) Add clothing that does not compromise safety (5 LOE 2a studies )

2) Covering the head that does not compromise safety (3 LOE 2 a studies)

3) Limit the amount of time in the water 
Summary of Key Articles/Literature Found and Level of Evidence:

\begin{tabular}{|c|c|c|c|c|}
\hline & Author(s) & Full Citation & $\begin{array}{l}\text { Summary of Article (provide a brief } \\
\text { summary of what the article adds to } \\
\text { this review) }\end{array}$ & $\begin{array}{l}\text { Level of } \\
\text { Evidence }\end{array}$ \\
\hline 1 & $\begin{array}{l}\text { American } \\
\text { National Red } \\
\text { Cross }\end{array}$ & $\begin{array}{l}\text { Water Safety Instructor } \\
\text { Manual. American National } \\
\text { Red Cross } 2009\end{array}$ & $\begin{array}{l}\text { p. } 115^{\text {"Maintain a water temperature }} \\
\text { of at least } 83^{\circ} \mathrm{F}\left(28.3^{\circ} \mathrm{C}\right) " \text { ". } \\
\text { p. } 148 . \text { "Typically, water temperature } \\
\text { that is at least } 83^{\circ} \mathrm{F}\left(28.3^{\circ} \mathrm{C}\right) \text { is more } \\
\text { comfortable for young children". }\end{array}$ & 5 \\
\hline 2 & $\begin{array}{l}\text { Aquatic } \\
\text { Exercise } \\
\text { Association }\end{array}$ & $\begin{array}{l}2010 \text { Standards \& } \\
\text { Guidelines: Aquatic Fitness } \\
\text { Programming. Aquatic } \\
\text { Exercise Association } 2010\end{array}$ & $\begin{array}{l}\text { p.3 "Children, fitness } 83-86 \mathrm{~F} / 28.3- \\
30 \mathrm{C} \text { " } \\
\text { "Children, swim lessons } \\
84+\mathrm{F} / 28.9+\mathrm{C} * \text { Varies with age, class } \\
\text { length, and programming; ideal learn to } \\
\text { swim programs is best suited for } 84- \\
89 \mathrm{~F} / 28.9-31.7 \mathrm{C} \text { when available" } \\
\text { "Infant programs } \\
\text { (4 and under) 90-93F / 32.2-33.9C* } \\
\text { (USA Swimming) }\end{array}$ & 5 \\
\hline 3 & $\begin{array}{l}\text { Beckman EL, } \\
\text { Reeves E }\end{array}$ & $\begin{array}{l}\text { Physiological implications as } \\
\text { to survival during immersion } \\
\text { in water at } 75^{\circ} \mathrm{F} \text {. Beckman } \\
\text { EL, Reeves E. Aerospace } \\
\text { Medicine. Nov. 1966, 1136- } \\
1142\end{array}$ & $\begin{array}{l}\mathrm{N}=24 \text { males were immersed to the } \\
\text { neck in a life vest in water } @ 75^{\circ} \mathrm{F} \text { for } \\
2-4 \text { hours, } 4-8 \text { hours or } 8-12 \text { hours. } \\
\text { Only } 6 \text { subjects completed the full } 12 \\
\text { hours. The rate of body heat loss is } \\
\text { directly related to specific gravity and } \\
\text { inversely related to \%BF. Rate of heat } \\
\text { loss is primarily a function of the area } \\
\text { of the body exposed to the cold water } \\
\text { and the thermal conductivity of that } \\
\text { area. Adipose tissue has a lower } \\
\text { thermal conductivity than muscle and } \\
\text { skin. Subjects with the lowest specific } \\
\text { gravity were the ones who stayed in the } \\
\text { water for the full } 12 \text { hours. }\end{array}$ & $2 a$ \\
\hline 4 & $\begin{array}{l}\text { Boutelier C, } \\
\text { Bougues L, } \\
\text { Timbal J }\end{array}$ & $\begin{array}{l}\text { Experimental study of } \\
\text { convective heat transfer } \\
\text { coefficient for the human } \\
\text { body in water. Boutelier C, } \\
\text { Bougues L, Timbal J, J Appl } \\
\text { Physiol:: Respirat Enviorn }\end{array}$ & $\begin{array}{l}\mathrm{N}=17 \text { male subjects were immersed } \\
\text { supine with the face out in water } \\
\text { ranging from } 33.7 \text { to } 18^{\circ} \mathrm{C} \text { at water } \\
\text { velocities between } 0 \text { and } 0.25 \mathrm{~m} / \mathrm{s} \text {. The } \\
\text { skin to water }(\Delta \mathrm{T}) \text { gradient decreases } \\
\text { when water velocity increases. }\end{array}$ & $2 a$ \\
\hline
\end{tabular}




\begin{tabular}{|c|c|c|c|c|}
\hline & & $\begin{array}{l}\text { Exercise Physiol 1977. } 42 \\
\text { (1): } 93-100\end{array}$ & $\begin{array}{l}\text { Shivering intensity at the same water } \\
\text { velocity and temperature conditions } \\
\text { varies with the fat layer thicknesses of } \\
\text { the subjects. }\end{array}$ & \\
\hline 5 & $\begin{array}{l}\text { Bullard RW, } \\
\text { Rapp GM }\end{array}$ & $\begin{array}{l}\text { Problems of body heat loss } \\
\text { in water immersion. Bullard } \\
\text { RW, Rapp GM. Aerospace } \\
\text { Med.1970 41(11): 1269- } \\
1277 .\end{array}$ & $\begin{array}{l}\text { This is a review article using a model } \\
\text { for developing concepts of heat loss in } \\
\text { water immersion. Heat energy flows } \\
\text { down the temperature gradient (Tc - } \\
\text { Tsk followed by Tsk - Tw) from trunk } \\
\text { to extremities to the cooler water. The } \\
\text { flow of heat energy is resisted by body } \\
\text { structural components and aided by } \\
\text { blood circulation. The resistance to } \\
\text { heat flow is very low when compared } \\
\text { to air and becomes even lower if water } \\
\text { and skin are in motion with respect to } \\
\text { each other. A thermogenic response } \\
\text { occurs by lowering temperatures. } \\
\text { Metabolic rate increases (shivering } \\
\text { theromogensis). Any type of muscle } \\
\text { activity (exercise) by the extremities } \\
\text { increases heat conductance (k) because } \\
\text { blood flow increases to the exercising } \\
\text { limbs and there is more surface area to } \\
\text { dissipate heat. } \\
\text { The average critical water temperature } \\
\text { (Tcw) is around } 33^{\circ} \mathrm{C} \text {. There is a great } \\
\text { deal of variation found in immersion } \\
\text { experiments. Subcutaneous fat } \\
\text { accounts for a major portion of such } \\
\text { variation. Physical condition } \\
\text { determines the ability to maintain a } \\
\text { high metabolic rate and attain thermal } \\
\text { equilibrium. }\end{array}$ & $2 \mathrm{a}$ \\
\hline 6 & Cabanac, M & $\begin{array}{l}\text { Temperature Regulation. } \\
\text { Cabanac, M. Annual Rev } \\
\text { Physiol 1975 37: 415-439 }\end{array}$ & $\begin{array}{l}\text { The term "temperature regulation" } \\
\text { means that there are mechanisms } \\
\text { defending the temperature of one or } \\
\text { several definable regions of the body. } \\
\text { Basic patterns of thermoregulatory } \\
\text { responses include a) heat production } \\
\text { through shivering and other metabolic } \\
\text { processes and b) vasomotor responses } \\
\text { resulting in heat transfer from core to } \\
\text { skin and, in turn, of heat loss to the } \\
\text { environment. It has been confirmed in }\end{array}$ & $2 \mathrm{a}$ \\
\hline
\end{tabular}




\begin{tabular}{|c|c|c|c|c|}
\hline & & & $\begin{array}{l}\text { experimental studies that skin vaso } \\
\text { constriction is a cold defense reaction } \\
\text { and skin vasodilation as a warm } \\
\text { defense reaction were compensated by } \\
\text { simultaneous opposite responses in the } \\
\text { thermal core. In man, direct } \\
\text { measurement of hypothalamic } \\
\text { temperature is not possible, nor is } \\
\text { independent stimulation of various } \\
\text { internal sensors. Thus, the only } \\
\text { combination that can be investigated in } \\
\text { man is the interaction between mean } \\
\text { Tsk and internal Tre or Tcore } \\
\text { temperatures }\end{array}$ & \\
\hline 7 & $\begin{array}{l}\text { Cannon P, } \\
\text { Keatinge WR }\end{array}$ & $\begin{array}{l}\text { "The metabolic rate and heat } \\
\text { loss of fat and thin men in } \\
\text { heat balance in cold and } \\
\text { warm water." Cannon P, } \\
\text { Keatinge WR, J Physiol } \\
1960 \text { 154: } 329-344\end{array}$ & $\begin{array}{l}\text { The purpose of this study was to } \\
\text { determine whether work assisted in } \\
\text { maintenance of Tb in water too cold to } \\
\text { maintain thermal equilibrium while } \\
\text { stationary. } \mathrm{N}=8 \text { healthy navy men } \\
\text { ages } 17-21 \text {, wearing a fleece lined } \\
\text { helmet covering much of the face and } \\
\text { immersed to the shoulders at } \\
\text { progressively lower temperatures until } \\
\text { Tre fell steadily after } 2.5 \text { hours. Five } \\
\text { men were then immersed at the next } \\
\text { lowest temperature and told to work as } \\
\text { hard as they could. Metabolic rate of } \\
\text { each man began to increase when Tw } \\
\text { was lowered below } 33^{\circ} \mathrm{C} \text {. Rise in MR } \\
\text { was steeper for thin vs fat men. For the } \\
5 \text { subjects immersed in the lower Tw, } \\
\text { Tre fell more rapidly during work than } \\
\text { at rest. }\end{array}$ & $2 \mathrm{a}$ \\
\hline 8 & $\begin{array}{l}\text { Carlson LD, } \\
\text { Hsieh ACL, } \\
\text { Fullerton F, } \\
\text { Elsner RW }\end{array}$ & $\begin{array}{l}\text { Immersion in cold water and } \\
\text { body tissue insulation. } \\
\text { Carlson LD, Hsieh ACL, } \\
\text { Fullerton F, Elsner RW. } \\
\text { Aviation Medicine, February } \\
1958145-152 \text {. }\end{array}$ & $\begin{array}{l}\mathrm{N}=9 \text { men immersed to the neck for } \\
\text { one hour in } 33,25 \text { and } 20^{\circ} \mathrm{C} \text {. Oxygen } \\
\text { consumption with temperature drop } \\
\text { indicates that subjects with a decrease } \\
\text { in insulation began shivering between } \\
4-5 \text { minutes after the bath temp } \\
\text { dropped } 2-3^{\circ} \mathrm{C} \text { (from } 33^{\circ} \mathrm{C} \text { ). Body } \\
\text { insulation varied with specific gravity. }\end{array}$ & $2 \mathrm{a}$ \\
\hline 9 & $\begin{array}{l}\text { Choi JS, Ahn, } \\
\text { DW, Choi JK, } \\
\text { Kim KR, Park }\end{array}$ & $\begin{array}{l}\text { Thermal balance of man in } \\
\text { water: prediction of deep } \\
\text { body temperature change. }\end{array}$ & $\begin{array}{l}\mathrm{N}=12 \text { healthy males with SCF of } \\
\text { between } 2.4 \text { to } 8.0 \mathrm{~mm} \text {. Subjects were } \\
\text { dressed in swim suits and immersed up }\end{array}$ & $2 \mathrm{a}$ \\
\hline
\end{tabular}




\begin{tabular}{|c|c|c|c|c|}
\hline & YS & $\begin{array}{l}\text { Choi JS, Ahn, DW, Choi JK, } \\
\text { Kim KR, Park YS. Appl } \\
\text { Human Sci 1996; 15(4): } \\
\text { 161-167. }\end{array}$ & $\begin{array}{l}\text { to the neck in Tw @ 15,20,25,30 or } \\
35^{\circ} \mathrm{C} \text { for } 1 \text { hour. An external } \\
\text { workload that could increase MR by } 60 \\
\mathrm{kcal} \cdot \mathrm{h}^{-1} \cdot \mathrm{m}^{-2} \text { was established } \\
\text { empirically. Tre fell linearly with time } \\
\text { after approximately } 20 \text { min. Rate of } \\
\text { fall was greater with lower } \\
\text { temperatures. } \\
\text { During exercise on a bicycle } \\
\text { ergometer, Tre remained the same for } \\
\text { the first } 15 \text { minutes and then declined } \\
\text { steadily. At any given Tw, the deep } \\
\text { body cooling rate was significantly } \\
\text { lower during exercise than at rest. The } \\
\text { general patterns of cold immersion } \\
\text { responses were similar but varied } \\
\text { considerably with } \% \text { BF. } \\
\text { For most subjects in this study Tre } \\
\text { declined in Tw below } 30^{\circ} \mathrm{C} \text {, regardless } \\
\text { of whether they were resting or } \\
\text { exercising. In the present study the } \\
\text { cooling rate was considerably smaller } \\
\text { with exercise than at rest. }\end{array}$ & \\
\hline 10 & $\begin{array}{l}\text { Collins KJ, } \\
\text { Easton JC, } \\
\text { Belfield-Smith } \\
\text { H, Exton-Smith } \\
\text { AN, Pluck RA }\end{array}$ & $\begin{array}{l}\text { Effects of age on body } \\
\text { temperature and blood } \\
\text { pressure in cold } \\
\text { environments. Collins KJ, } \\
\text { Easton JC, Belfield-Smith H, } \\
\text { Exton-Smith AN, Pluck RA. } \\
\text { Clinical Science 1985; 69: } \\
465-470\end{array}$ & $\begin{array}{l}\mathrm{N}=9 \text { subjects ( } 5 \text { in age range } 63-70 \\
\text { and } 4 \text { in age range } 18-24 \text { years) were } \\
\text { exposed to Ta } @ 6,9,12,15 \text {, and } \\
23^{\circ} \mathrm{C} \text {. (air blown over the body surface } \\
\text { at } 0.5 \mathrm{~m} / \mathrm{s} \text { ) four hours/day for } 7-10 \\
\text { days. Subjects wore standard open- } \\
\text { collar battledress, shirt, underclothes } \\
\text { and civilian shoes ( } 1.5 \mathrm{CLO} \text { ) and } \\
\text { remained seated during the exposure. } \\
\text { There was no evidence of acclimation } \\
\text { in either group. The fall in core } \\
\text { temperature was significantly greater at } \\
6^{\circ} \mathrm{C} \text { for older than younger subjects. } \\
\text { No significant differences of thermal } \\
\text { comfort sensation were found } @ \text { Tw } \\
15,12,9 \text { and } 6^{\circ} \mathrm{C} \text {. } \\
\text { There was a significant increase in } \mathrm{BP} \\
@ 6^{\circ} \mathrm{C} \text { and was greater in old than in } \\
\text { the young. At } 15^{\circ} \mathrm{C} \text { there were no } \\
\text { significant changes in BP in either } \\
\text { group. HR decreased sharply over the } \\
\text { first } 15 \text { minutes for the young in } 6^{\circ} \mathrm{C} \text {, }\end{array}$ & $\begin{array}{c}2 \mathrm{a} \\
2 \mathrm{aE}\end{array}$ \\
\hline
\end{tabular}




\begin{tabular}{|c|c|c|c|c|}
\hline & & & $\begin{array}{l}\text { with older subjects experiencing a } \\
\text { steady falling } \mathrm{HR} \text { in } 6 \text { and } 12^{\circ} \mathrm{C} \text {. At } \\
15^{\circ} \mathrm{C} \text {, there were no significant } \mathrm{HR} \\
\text { changes in either group. }\end{array}$ & \\
\hline 11 & $\begin{array}{l}\text { Costill D L, } \\
\text { Cahill PJ, Eddy } \\
\text { D }\end{array}$ & $\begin{array}{l}\text { Metabolic responses to } \\
\text { submaximal exercise in three } \\
\text { water temperatures. Costill } \\
\text { DL, Cahill PJ, Eddy D. J } \\
\text { Appl Physiol. } 1967 \text { 22(4): } \\
628-632\end{array}$ & $\begin{array}{l}\text { In Tw } 17.4^{\circ}, 26.8^{\circ} \& 33.1^{\circ} \mathrm{C}, 8 \text { men, } \\
\text { (mean age } 21.13 \text {, mean } \% \mathrm{BF} 7.7 \text { ) } \\
\text { participated in submaximal swimming } \\
\text { for } 20 \text { minutes. Tsk during exercise } \\
\text { remained higher than Tw in all cases } \\
\text { but thermal differential was inversely } \\
\text { related. Mean Tre increase during } \\
\text { exercise was greatest @ } 33.1^{\circ} \mathrm{C} \text { and } \\
\text { least @ } 17.4^{\circ} \mathrm{C} \text {. Tre decreased during } \\
\text { recovery more rapidly in } 17.4^{\circ} \mathrm{C} \text { than } \\
\text { in } 26.8^{\circ} \mathrm{C} \text {. Tre decrease at } 17.4 \text { was } \\
\text { lower than pre-immersion Tre. }\end{array}$ & $2 \mathrm{a}$ \\
\hline 12 & $\begin{array}{l}\text { Craig AB, } \\
\text { Dvorak M }\end{array}$ & $\begin{array}{l}\text { Thermal regulation during } \\
\text { water immersion. Craig, A } \\
\text { B, Dvoak M. J Appl } \\
\text { Physiol, } 1966 \text { 21(5): } 1577 \\
1585\end{array}$ & $\begin{array}{l}\mathrm{N}=10 \text { men immersed for one hour, } \\
\text { semi recumbent with water just below } \\
\text { the chin in Tw @ }(24,26,28,30,32 \text {, } \\
34,36 \text { and } 37^{\circ} \mathrm{C} \text {. When Tw was } 36 \text { or } \\
37^{\circ} \mathrm{C} \text {, there was a continuous increase } \\
\text { in central temperature. In Tw @ } 35^{\circ} \mathrm{C} \\
\text { or lower, Tc were below control values } \\
\text { at the end of } 60 \text { minutes. In Tw @ } \\
30^{\circ} \mathrm{C} \text { or less, there was an initial rise in } \\
\text { Tre. V } 0{ }_{2} \text { would increase in water less } \\
\text { than } 30^{\circ} \mathrm{C} \text { if time was approximately } \\
40 \text { minutes or less. Subjective } \\
\text { observations: subjects were most } \\
\text { comfortable in } 34-36^{\circ} \mathrm{C} \text {; tired and } \\
\text { restless at } 37^{\circ} \mathrm{C} \text {; cold initially at } 30 \text { and } \\
32^{\circ} \mathrm{C} \text { but feelings passed in the first } 3-5 \\
\text { minutes; } 28^{\circ} \mathrm{C} \text { seemed the hardest to } \\
\text { tolerate; } 24 \text { and } 26^{\circ} \mathrm{C} \text { didn't seem so } \\
\text { difficult after initial responses to } \\
\text { immersion. }\end{array}$ & $2 \mathrm{a}$ \\
\hline 13 & $\begin{array}{l}\text { Craig AB, } \\
\text { Dvorak M }\end{array}$ & $\begin{array}{l}\text { Thermal regulation of man } \\
\text { exercising during water } \\
\text { immersion. Craig AB, } \\
\text { Dvorak M. J Appl Physiol } \\
\text { 1968. } 25 \text { (1) 28-35. }\end{array}$ & $\begin{array}{l}\mathrm{N}=10 \text { male subjects exercised at two } \\
\text { workloads (light }=.701 / \mathrm{min} \text {; heavy } .92 \\
\text { 1/min) on a bicycle ergometer nearly } \\
\text { horizontal, and immersed with the head } \\
\text { out in Tw @ } 24,26,28,30,31 \text { and } \\
32^{\circ} \mathrm{C} \text {. With light work, Tre continues } \\
\text { to decline in Tw less than } 32^{\circ} \mathrm{C} \text {. At } \\
\text { high workload the initial decrease in } \\
\text { Tre was followed by an increase when }\end{array}$ & $2 \mathrm{a}$ \\
\hline
\end{tabular}




\begin{tabular}{|c|c|c|c|c|}
\hline & & & $\begin{array}{l}\text { water temperature was } 28-32^{\circ} \mathrm{C} \text {. } \\
\text { With light workload the Ts necessary } \\
\text { to prevent } \Delta \text { Tre would be } 34^{\circ} \mathrm{C} \text { for } \\
\text { subjects whose heat production is } \\
\text { approximately } 2.5 \mathrm{X} \text { resting. For heavy } \\
\text { workloads, an equivalent Tw would be } \\
\text { approximately } 29^{\circ} \mathrm{C} \text {. }\end{array}$ & \\
\hline 14 & Falk B & $\begin{array}{l}\text { Effects of thermal stress } \\
\text { during rest and exercise in } \\
\text { the paediatric population. } \\
\text { Falk B, Sports Med } 1998 \\
\text { Apr; 25(4): } 221-40\end{array}$ & $\begin{array}{l}\text { This is a review of age related } \\
\text { differences in the human } \\
\text { thermoregulatory system. Physical } \\
\text { and physiological differences between } \\
\text { children and adults may explain the } \\
\text { differences in thermoregulation. The } \\
\text { main physical difference is the higher } \\
\text { surface area-to-mass ratio of children. } \\
\text { This increases heat loss. The main } \\
\text { physiological difference btw adults and } \\
\text { children is the sweating mechanism, } \\
\text { affecting thermoregulation in the heat } \\
\text { but not in the cold. Children have a } \\
\text { higher metabolic cost of locomotion } \\
\text { that may be advantageous in the cold } \\
\text { by increasing heat production. } \\
\text { In Tn temperatures, children have } \\
\text { similar rectal temperatures but higher } \\
\text { skin temps. In a cold environment, } \\
\text { children have lower skin temperatures } \\
\text { as compared to adults, indicating } \\
\text { greater vasoconstriction. Metabolic } \\
\text { heat is also greater in the cold for } \\
\text { children than adults. }\end{array}$ & 3 \\
\hline 15 & $\begin{array}{l}\text { Falk B, Bar-or } \\
\mathrm{O}, \text { Smolander J, } \\
\text { and Frost G }\end{array}$ & $\begin{array}{l}\text { Response to rest and } \\
\text { exercise in the cold: effects } \\
\text { of age and aerobic fitness. } \\
\text { Falk B, Bar-or O, Smolander } \\
\text { J, and Frost G. J Appl } \\
\text { Physiol, 1994. 76(1): 72-78 }\end{array}$ & $\begin{array}{l}\mathrm{N}=3 \text { groups of healthy men: } 1) 8 \\
\text { young adults (YA), ages } 21-29,2) 8 \\
\text { well trained seniors (TS), ages } 55-66 \\
\text { and } 3 \text { ) } 11 \text { untrained seniors (different } \\
\mathrm{VO}_{2 \max } \text { than TS) with no significant } \\
\text { differences in anthropometric } \\
\text { measures. Subjects were exposed to } 20 \\
\text { minutes @ themoneutral }\left(22^{\circ} \mathrm{C}\right), 10 \\
\text { minutes at rest and } 10 \text { minutes cycle at } \\
\text { a pre-determined work rate } \\
\text { (approximately } 50 \mathrm{~W} \text { which is } \\
\text { equivalent to most occupational } \\
\text { activities). After } 1 \text {-hr of rest they were } \\
\text { exposed to } 5^{\circ} \mathrm{C} \text { for } 30 \text { minutes of rest }\end{array}$ & $2 \mathrm{a}$ \\
\hline
\end{tabular}




\begin{tabular}{|c|c|c|c|c|}
\hline & & & $\begin{array}{l}\text { and then } 30 \text { minutes at the same work } \\
\text { rate as the thermoneutral trial. } \\
\text { The findings in this study show an age- } \\
\text { related diminished ability to maintain } \\
\text { core temperature during rest and low } \\
\text { intensity exercise in the cold. YA were } \\
\text { able to maintain Tre with this work rate } \\
\text { but TS and US were not. }\end{array}$ & \\
\hline 16 & $\begin{array}{l}\text { Farnell G, } \\
\text { Pierce J, Demes } \\
\text { R, } \\
\text { Collingsworth } \\
\text { T, Ryan EJ, } \\
\text { Bellar D, Bliss } \\
\text { MV, Barkley } \\
\text { JE, Kamimori } \\
\text { GH, Glickman } \\
\text { EL }\end{array}$ & $\begin{array}{l}\text { Effects of body composition } \\
\text { on thermoregulatory } \\
\text { responses during cold water } \\
\text { immersion in healthy males. } \\
\text { Farnell G, Pierce J, Demes } \\
\text { R, Collingsworth T, Ryan } \\
\text { EJ, Bellar D, Bliss MV, } \\
\text { Barkley JE, Kamimori GH, } \\
\text { Glickman EL. Med Sci } \\
\text { Sport Exercise, } 2008 \\
\text { 40(5):S228 }\end{array}$ & $\begin{array}{l}\mathrm{N}=6 \text { low fat }(\mathrm{LF}, 10.1 \pm 1.4 \% \mathrm{BF}) \text { and } 5 \\
\text { high fat }(\mathrm{HF}, 28.1 \pm 3.5 \% \mathrm{BF}) \text { were } \\
\text { immersed to the neck in water @ } 18 \text {, } \\
22,26^{\circ} \mathrm{C} \text { for a baseline of } 10 \text { minutes, } \\
\text { followed by } 120 \text { minute immersion and } \\
\text { a } 15 \text { minute re-warming period on a } \\
\text { cycle ergometer. } \\
\text { LF subjects had a greater decrease in } \\
\text { Tre and greater increases in } \mathrm{V}_{2} \text { over } \\
\text { time compared with } \mathrm{HF} \text { subjects. High } \\
\text { fat subjects tolerated cold water } \\
\text { immersion more efficiently and } \\
\text { effectively than LF individuals. }\end{array}$ & $2 a$ \\
\hline 17 & $\begin{array}{l}\text { Ferretti G, } \\
\text { Veicsteinas A, } \\
\text { Rennie, DW }\end{array}$ & $\begin{array}{l}\text { Reginal heat flows of resting } \\
\text { and exercising man } \\
\text { immersed in cool water. } \\
\text { Ferretti G, Veicsteinas A, } \\
\text { Rennie DW. J Appl Physiol } \\
\text { 1988, 64(3): 1239-1248 }\end{array}$ & $\begin{array}{l}\mathrm{N}=9 \text { men immersed to the neck in Tw } \\
\text { ranging from } 22-32^{\circ} \mathrm{C} \text {. This study } \\
\text { included } 3 \text { Protocols: } 1) 3 \text { hours at rest } \\
\text { @ Tw below Tcw 2) } 3 \text { hours with } \\
\text { light exercise }\left(30 \% \mathrm{~V}_{2} \text { max and } 3\right) 3 \\
\text { hours with heavy exercise @ Tw } \\
\left.\text { below Tcw ( } 70 \% \mathrm{~V} 0_{2 \mathrm{max}}\right) \text {. Subjects } \\
\text { were only able to remain immersed } 80 \text { - } \\
170 \text { minutes due to onset of shivering. } \\
\text { The temperature at which thermal } \\
\text { balance is reached in a } 3 \text { hour } \\
\text { immersion is Tw }=\mathrm{Tcw}+1.5^{\circ} \mathrm{C} \\
\text { Exercise in the water may increase core } \\
\text { temperature depending on the intensity } \\
\text { of the exercise, body obesity, area to } \\
\text { body weight ratio and whether or not } \\
\text { the limbs are being exercised. There is } \\
\text { a preferrential heat exchange from the } \\
\text { limbs to water because of the greater } \\
\text { percentage of total body area in } \\
\text { comparrison to the trunk. Circulation } \\
\text { to the limbs is reduced to a minimum } \\
\text { in Tcw. }\end{array}$ & $2 \mathrm{a}$ \\
\hline
\end{tabular}




\begin{tabular}{|c|c|c|c|c|}
\hline 18 & $\begin{array}{l}\text { Frank SM, Jaja } \\
\text { A, Bulcao C, } \\
\text { Goldstein DS. }\end{array}$ & $\begin{array}{l}\text { Age-related } \\
\text { thermoregulatory differences } \\
\text { during core cooling in } \\
\text { humans. Frank SM, Jaja A, } \\
\text { Bulcao C, Goldstein DS. } \\
\text { Am J Physiol, 2000; 279: } \\
\text { R349-354 }\end{array}$ & $\begin{array}{l}\mathrm{N}=8 \text { younger subjects }(18-23) \text { and } 8 \\
\text { older subjects }(55-71) \text { were given a } \\
\text { cold fluid intraveneously over a period } \\
\text { of } 30 \text { minutes to compare Tre } \\
\text { thresholds for vasoconstriction, heat } \\
\text { production (shivering) and perceived } \\
\text { thermal comfort among other things. } \\
\text { Older subjects had a significantly } \\
\text { greater \%BF. Maximum intensities of } \\
\text { both vasoconstriction and total body } \mathrm{O}^{2} \\
\text { consumption were less in the older } \\
\text { group. Mean maximum shivering } \\
\text { score was lower in the older group. } \\
\text { Subjective thermal comfort scores were } \\
\text { similar in the two age groups despite } \\
\text { the lower Tc in the older group. } \\
\text { The results indicate that all three major } \\
\text { cold responses are in some way } \\
\text { impaired with age. }\end{array}$ & $2 \mathrm{a}$ \\
\hline 19 & $\begin{array}{l}\text { Froese } \mathrm{G} \text { and } \\
\text { Burton AC }\end{array}$ & $\begin{array}{l}\text { Heat losses from the human } \\
\text { head. Froese G and Burton } \\
\text { AC. J Appl Physiol 1957, } \\
\text { 10(2): } 235-241\end{array}$ & $\begin{array}{l}\text { This study measured the } \\
\text { nonevaporative heat loss of } \mathrm{N}=3 \\
\text { subjects, with unprotected heads but } \\
\text { adequately clothed bodies, at } \\
\text { temperatures between } 32^{\circ} \mathrm{C} \text { and } \\
-21^{\circ} \mathrm{C} \text {. The tissue insulation of the } \\
\text { head apprears to be constant over a } \\
\text { wide range of temperatures. The } \\
\text { findings support the point that there is } \\
\text { little or no vasoconstriction in the head } \\
\text { in repsonse to cold. It can be estimated } \\
\text { from this study that for an average } \\
\text { resting subject, the heat balance of the } \\
\text { head (heat loss balanced by heat } \\
\text { production) occurs at around } 22^{\circ} \mathrm{C} \\
\left.\text { ( } 71.6^{\circ} \mathrm{F}\right) \text {. }\end{array}$ & $2 \mathrm{a}$ \\
\hline 20 & $\begin{array}{l}\text { Fujishima K, } \\
\text { Shimizu T, } \\
\text { Ogaki T, Hotta } \\
\text { N, Kanaya S, } \\
\text { Shono T, Ueda } \\
\text { T }\end{array}$ & $\begin{array}{l}\text { Thermoregulatory responses } \\
\text { to low-intensity prolonged } \\
\text { swimming in water at } \\
\text { various temperatures and } \\
\text { treadmill walking on land. } \\
\text { Fujishima K, Shimizu T, } \\
\text { Ogaki T, Hotta N, Kanaya S, } \\
\text { Shono T, Ueda T. J Physiol } \\
\text { Anthropol, 2001 20(3):199- } \\
206\end{array}$ & $\begin{array}{l}\mathrm{N}=6 \text { male college swimmers (age } \\
19.8 \pm 0.9 \text { and } \% \mathrm{BF} 13.2 \pm 3.4 \text { ) swam } \\
120 \text { minutes of breaststroke in a swim } \\
\text { flume at a constant speed of } 0.4 \mathrm{~m} / \mathrm{sec}- \\
1,\left(\text { approximately } 50 \% \mathrm{VO}_{2} \max @\right. \\
23^{\circ}, 43 \% \max @ 28^{\circ} \text { and } 42 \% \max @ \\
\left.33^{\circ} \mathrm{C}\right) . \\
\text { Tre steadily declined and was } \\
\text { significant after } 20 \text { minutes @ } 23 \& 28 \\
\text { Tre during swimming in } 23 \text { and } 28^{\circ} \mathrm{C}\end{array}$ & $2 \mathrm{a}$ \\
\hline
\end{tabular}




\begin{tabular}{|c|c|c|c|c|}
\hline & & & $\begin{array}{l}\text { decreased significantly compared to } \\
\text { temperatures at rest in air. There was } \\
\text { no significant change in the } 33^{\circ} \mathrm{C} \text { trial } \\
\text { compared to air }\end{array}$ & \\
\hline 21 & $\begin{array}{l}\text { Galbo H, } \\
\text { Houston ME, } \\
\text { Christensen NJ, } \\
\text { Holst JJ, } \\
\text { Nielsen B, } \\
\text { Nygaard E, and } \\
\text { Suzuki J }\end{array}$ & $\begin{array}{l}\text { The effect of water } \\
\text { temperature on the hormonal } \\
\text { response to prolonged } \\
\text { swimming. Galbo H, } \\
\text { Houston ME, Christensen } \\
\text { NJ, Holst JJ, Nielsen B, } \\
\text { Nygaard E, and Suzuki J } \\
\text { Acta Physiol Scand, } 1979 \\
\text { 105: 326-337 }\end{array}$ & $\begin{array}{l}\mathrm{N}=6 \text { men swimming breaststroke for } \\
60 \text { minutes at a speed requiring } 65 \% \\
\mathrm{VO}_{2} \text { max }\left(\text { determined in } 27^{\circ} \mathrm{C} \text { water) } @\right. \\
21^{\circ}, 27^{\circ} \text { and } 33^{\circ} \mathrm{C} \text {. } \\
\text { Tre increased significantly in } 33^{\circ} \text { and } \\
\text { to a smaller extent in } 27^{\circ} \mathrm{C} \text {. } \\
\text { Tre decreased in } 21^{\circ} \mathrm{C} \\
\text { Swimmers perceived that } 21^{\circ} \mathrm{C} \text { was too } \\
\text { cold and felt "enclosed in heat in } 33^{\circ} \mathrm{C} \\
\text { and found it more difficult to complete } \\
\text { the swim at these temps than } @ 27^{\circ} \mathrm{C}\end{array}$ & $2 \mathrm{a}$ \\
\hline 22 & $\begin{array}{l}\text { Giesbrecht GG, } \\
\text { Lockhert TL, } \\
\text { Bristow GK, } \\
\text { and Steinman } \\
\text { AM }\end{array}$ & $\begin{array}{l}\text { Thermal effects of dorsal } \\
\text { head immersion in cold } \\
\text { water on nonshivering } \\
\text { humans. Giesbrecht GG, } \\
\text { Lockhert TL, Bristow GK, } \\
\text { and Steinman AM. J Appl } \\
\text { Physiol, 2005 99: 1958- } \\
1964\end{array}$ & $\begin{array}{l}\mathrm{N}=6 \text { male volunteers were immersed } \\
4 \text { times for up to } 60 \text { minutes in } 12^{\circ} \mathrm{C} \\
\text { water. An insulated hoodless dry suit } \\
\text { or two different floatation devices was } \\
\text { used to create four conditions: } 1 \text { ) body } \\
\text { insulated, head out, 2) body insulated, } \\
\text { dorsal head immersion, } 3 \text { ) body } \\
\text { exposed, head and upper chest out, } 4) \\
\text { body exposed and dorsal head } \\
\text { immersion and chest immersion. } \\
\text { When the body was insulated, dorsal } \\
\text { head immersion did not affect core } \\
\text { cooling rate compared with head-out } \\
\text { conditions. When the body was } \\
\text { exposed, the core cooling rate } \\
\text { increased by } 40 \% \text { from head out } \\
\text { condition to dorsal head and upper } \\
\text { chest immersed. }\end{array}$ & $2 \mathrm{a}$ \\
\hline 23 & $\begin{array}{l}\text { Glickman EL, } \\
\text { Caine-Bish N, } \\
\text { Cheatham CC, } \\
\text { Blegen M, } \\
\text { Potkanowicz } \\
\text { ES, }\end{array}$ & $\begin{array}{l}\text { The influence of age on } \\
\text { thermosensitivity during } \\
\text { cold water immersion. } \\
\text { Glickman EL, Caine-Bish N, } \\
\text { Cheatham CC, Blegen M, } \\
\text { Potkanowicz ES, } \\
\text { Wilderness and Environ } \\
\text { Med. } 2002 \text { Fall; 13(3):194- } \\
202\end{array}$ & $\begin{array}{l}\mathrm{N}=15 \text { young men (YNG, } 18-30 \text { and } \% \\
\mathrm{BF} 10.9 \pm 2.9) \text { and } 7 \text { old men (OLD, } \\
40-55 \text { and } \% \mathrm{BF} 13.7 \pm 8.4) \text { were } \\
\text { immersed to the first thoracic } \\
\text { vertebrae, with limbs separated in Tw } \\
\text { @ } 20^{\circ} \mathrm{C} \text { for } 3 \text { phases over a } 60 \text { minute } \\
\text { period to determine if there are } \\
\text { significant differences in heat } \\
\text { production (HP), esophogeal } \\
\text { temperature (Tes), mean skin } \\
\text { temperature (Tsk), and central }\end{array}$ & $2 \mathrm{a}$ \\
\hline
\end{tabular}




\begin{tabular}{|c|c|c|c|c|}
\hline & & & $\begin{array}{l}\text { thermosensitivity (defined as an } \\
\text { increase in HP with controlled } \\
\text { manipulation of Tes). } \\
\text { Tre declined in both age groups at rest } \\
\text { in } 21^{\circ} \mathrm{C} \text { water. } \\
\text { This study found that YNG and OLD } \\
\text { subjects responded similarly in all } \\
\text { responses to Tw@ } 20^{\circ} \mathrm{C} \text {. }\end{array}$ & \\
\hline 24 & $\begin{array}{l}\text { Glickman- } \\
\text { Weiss EL, Goss } \\
\text { FL, Robertson } \\
\text { RJ, Metz KF, } \\
\text { Cassinelli DA }\end{array}$ & $\begin{array}{l}\text { Physiological and thermal } \\
\text { responses of males with } \\
\text { varying body compositions } \\
\text { during immersion in } \\
\text { moderately cold water. } \\
\text { Glickman-Weiss E L, Goss } \\
\text { F L, Robertson R J, Metz K } \\
\text { F, Cassinelli D A. Aviat } \\
\text { Space Environ Med 1991, } \\
62: 1063-1067\end{array}$ & $\begin{array}{l}\mathrm{N}=24 \text { male volunteers, ages } 20-35 \text { (12 } \\
\text { low fat subjects; } 9-12 \% \mathrm{BF} \text { and } 12 \text { high } \\
\text { fat subjects; } 18-22 \% \mathrm{BF}) \text { immersed to } \\
\text { the first thoracic vertebrae and } \\
\text { randomly assigned for a } 90 \text { minute } \\
\text { immersion in one of } 3 \mathrm{Tw}(18,22 \text { or } \\
\left.26^{\circ} \mathrm{C}\right) \text {. } \\
\text { After the first } 5 \text { minutes, Tsk } \\
\text { approached Tw and remained } \\
\text { unchanged in both groups. } \\
\text { Tre delcined as a function of time and } \\
\text { were similare for all subjects at each } \\
\text { time pont over the } 90 \text { minutes. } \\
\text { This investigation demonstrated that } \\
\text { the magnitude of the increase in V } 0_{2} \\
\text { during cold water immersion is } \\
\text { primarily influenced by the } \\
\text { physiological characteristics of the } \\
\text { subjects. LF subjects typically have a } \\
\text { greater } 0_{2} \text { response than HF subjects. }\end{array}$ & $2 \mathrm{a}$ \\
\hline 25 & $\begin{array}{l}\text { Glickman- } \\
\text { Weiss EL, } \\
\text { Nelson AG, } \\
\text { Hearon CM, } \\
\text { Goss }^{2} \text { FL, } \\
\text { Robertson }{ }^{2} \text { RJ, } \\
\text { Cassinelli DA }\end{array}$ & $\begin{array}{l}\text { Effects of body morphology } \\
\text { and mass on thermal } \\
\text { responses to cold water: } \\
\text { revisited. Glickman-Weiss } \\
\text { EL, Nelson AG, Hearon } \\
\text { CM, Goss }{ }^{2} \text { FL, Robertson }{ }^{2} \\
\text { RJ, Cassinelli DA. Eur J } \\
\text { Appl Physiol. 1993, 66: 299- } \\
303\end{array}$ & $\begin{array}{l}\mathrm{N}=7 \text { males college students ( } 4 \text { with } \\
\text { large mass and } \% \mathrm{BF} 14.5 \pm 4.1 \text { ) and } 3 \\
\text { with small mass and } \% \mathrm{BF} 16.5 \pm 3.5 \text { )), } \\
\text { with similar total body fat, were } \\
\text { immersed to the first thoracic vertebrae } \\
\text { for } 120 \text { minutes in stirred water } @ \\
18^{\circ} \mathrm{C} \text {. } \\
\text { Tre declined for all subjects as a } \\
\text { function of time. } \\
\text { Tissue insulation was higher in LM } \\
\text { subjects compared to SM subjects } \\
\text { (non-significant differences). After } 5 \\
\text { minutes Tsk approached Tw and } \\
\text { remained unchanged for both groups } \\
\text { throughout the experiment. There were } \\
\text { no differences between groups in } 0_{2} \\
\text { response, thermal sensation response or }\end{array}$ & $2 \mathrm{a}$ \\
\hline
\end{tabular}




\begin{tabular}{|c|c|c|c|c|}
\hline & & & $\begin{array}{l}\text { tissue insulation. Differences in } \\
\text { surface area to mass ratio did not result } \\
\text { in significant differences in heat loss } \\
\text { during rest in cold water. }\end{array}$ & \\
\hline 26 & $\begin{array}{l}\text { Golden F St.C, } \\
\text { Tipton MJ }\end{array}$ & $\begin{array}{l}\text { Human thermal responses } \\
\text { during leg only exercise in } \\
\text { cold water. Golden F St.C, } \\
\text { Tipton MJ J Physiol 1987; } \\
\text { 391-401 }\end{array}$ & $\begin{array}{l}\mathrm{N}=15 \text { healthy male subjects (btw ages } \\
17 \text { and } 34 \text { ) performed two } 40 \text { minute } \\
\text { head-out immersions in Tw } @ 15^{\circ} \mathrm{C} \text {. } \\
\text { One trial was dynamic immersion (leg } \\
\text { exercise on a modified bicycle } \\
\text { ergometer, working at the same relative } \\
\text { workload; } \mathrm{VO}_{2} 1 \cdot 81 \mathrm{O}_{2} \mathrm{~min}^{-1} \text { ) and one } \\
\text { static immersion. The results are for } \\
\text { the period between minutes } 10 \text { and } 30 \\
\text { and compare static immersion to } \\
\text { dynamic immersion. Mean Tsk did not } \\
\text { differ until minute } 30 \text { then was higher } \\
\text { for static immersion. Tre fell by a } \\
\text { greater amount in static v dynamic } \\
\text { immersion. The 'leg-only' exercise in } \\
\text { this study resulted in smaller falls in } \\
\text { Tre when compared to an equivalent } \\
\text { static immersion. }\end{array}$ & $2 \mathrm{a}$ \\
\hline 27 & $\begin{array}{l}\text { Hayward JS, } \\
\text { Collis M, } \\
\text { Eckerson JD }\end{array}$ & $\begin{array}{l}\text { Thermographic evaluation of } \\
\text { relative heat loss areas of } \\
\text { man during cold water } \\
\text { immersion. Aerosp Med } \\
1973 \text { Jul; } 44(7): 708-711\end{array}$ & $\begin{array}{l}4 \text { male subjects were immersed in } \\
7.5^{\circ} \mathrm{C} \text { water for } 15 \text { minutes, at rest } \\
\text { (holding a life ring) and swimming a } \\
\text { "semi-backstroke" with a sculling } \\
\text { motion of the arms. } \\
\text { In all instances, the warmest areas were } \\
\text { the trunk and upper arms. The legs } \\
\text { were generally cooler. It appears that } \\
\text { the greatest heat loss areas during static } \\
\text { immersion are the lateral thorax, upper } \\
\text { chest and back and groin. During } \\
\text { swimming there was higher heat loss in } \\
\text { those same areas. }\end{array}$ & $2 \mathrm{a}$ \\
\hline 28 & $\begin{array}{l}\text { Hayward MG, } \\
\text { Keatinge WR }\end{array}$ & $\begin{array}{l}\text { Roles of subcutaneous fat } \\
\text { and thermoregulatory } \\
\text { reflexes in determining } \\
\text { ability to stabilize body } \\
\text { temperature in the water. } \\
\text { Hayward MG, Keatinge } \\
\text { WR. J Physiol. 1981, 320: } \\
\text { 229-251 }\end{array}$ & $\begin{array}{l}\mathrm{N}=14 \text { adult men and women, ages } 18- \\
27 \text { were repeatedly immersed in water } \\
\text { (including a water spray over the head } \\
\text { to simulate total immersion) in } \\
\text { decreasing water temperatures until Tre } \\
\text { stabilized or dropped below } 35^{\circ} \mathrm{C} \text {. } \\
\text { After establishing the lowest Tw at } \\
\text { rest, subjects performed a rowing type } \\
\text { motion while pedaling a bicycle during } \\
\text { a } 30 \text { minute immersion. The lowest }\end{array}$ & $2 \mathrm{a}$ \\
\hline
\end{tabular}




\begin{tabular}{|c|c|c|c|c|}
\hline & & & $\begin{array}{l}\text { Tw in which different young adults } \\
\text { could stabilize Tb was found to vary } \\
\text { from } 32{ }^{\circ} \mathrm{C} \text { to less than } 12^{\circ} \mathrm{C} \text { (due to } \\
\text { large differences in both total body } \\
\text { insulation and metabolic heat } \\
\text { production). Total body insulation per } \\
\text { unit surface area, in the coldest water } \\
\text { allowing stability, was quite closely } \\
\text { determined by mean subcutaneous fat } \\
\text { thickness, regardless of differences in } \\
\text { distribution of fat between men and } \\
\text { women. At rest, subjects with larger } \\
\text { SCF thickness could generally stabilize } \\
\text { Tb in colder water. Exercise reduced } \\
\text { internal insulation only in muscular } \\
\text { parts and increased heat loss by } \\
\text { exposing more skin surface. }\end{array}$ & \\
\hline 29 & $\begin{array}{l}\text { Hayward JS, } \\
\text { Eckerson JD, } \\
\text { Collis ML }\end{array}$ & $\begin{array}{l}\text { Thermal balance and } \\
\text { survival time prediction of } \\
\text { man in cold water. Hayward } \\
\text { JS, Eckerson JD, Collis ML. } \\
\text { J Physiol Pharmacol } 1975 \\
53: 21-32\end{array}$ & $\begin{array}{l}\mathrm{N}=6 \text { male and } 6 \text { female subjects ages } \\
19-29 \text {, immersed at rest with a Kapok } \\
\text { vest and light clothing in Tw@ } 4.6 \text {, } \\
10.5 \text { and } 18.2^{\circ} \mathrm{C} \text { and slow swimming } \\
@ 10.5^{\circ} \mathrm{C} \text { for } 25-60 \text { minutes } \\
\text { (determined by Tw and limited by Tre } \\
\text { of } 35.0^{\circ} \mathrm{C} \text { or less). } \\
\text { Hypothermia resulted in all conditions } \\
\text { while at rest. Hypothetic zero heat } \\
\text { production occurs at Tw } 38^{\circ} \mathrm{C} \text { and is } \\
\text { less than } 1^{\circ} \mathrm{C} \text { greater than actual Tre. } \\
\text { Extrapolation of this regression to zero } \\
\text { cooling rate occurs at Tw } 23.1^{\circ} \mathrm{C} \\
\text { (critical temperature). Cooling rate } \\
\text { was found to be } 35 \% \text { higher while } \\
\text { swimming at } 10.5^{\circ} \mathrm{C} \text {. }\end{array}$ & $2 \mathrm{a}$ \\
\hline 30 & $\begin{array}{l}\text { Holmer I, Bergh } \\
\mathrm{U}\end{array}$ & $\begin{array}{l}\text { Metabolic and thermal } \\
\text { responses to swimming in } \\
\text { varying temperatures. } \\
\text { Holmer I, Bergh U. J Appl } \\
\text { Physiol. } 1974 \text { 37(5): 702- } \\
705\end{array}$ & $\begin{array}{l}\mathrm{N}=5 \text { swam at } 50 \% \mathrm{VO}_{2} \text { max } \\
\text { (determined by max test) for } 20 \\
\text { minutes in water } @ 18^{\circ}, 26^{\circ} \text { and } 34^{\circ} \mathrm{C} \\
\text { and then performed a test at maximum } \\
\text { intensity. } \\
\text { Tes rose exponentially in } 26 \text { and } 34^{\circ} \mathrm{C} \\
\text { with maximal work. } \\
\text { Tes rose in } 34^{\circ} \mathrm{C} \text { for the submaximal } \\
\text { test and was lower in } 18^{\circ} \mathrm{C} \text { in } 4 \text { of } 5 \\
\text { subjects. } \\
\text { Tes in } 18^{\circ} \text { and } 26^{\circ} \mathrm{C} \text { was found to be } \\
\text { related to the thickness of }\end{array}$ & $2 \mathrm{a}$ \\
\hline
\end{tabular}




\begin{tabular}{|c|c|c|c|c|}
\hline & & & $\begin{array}{l}\text { subcutaneous fat. } \\
\text { The leanest subject (\%BF 3.8) could } \\
\text { not sustain Tes with submaximal work } \\
\text { in } 26 \text { or } 18^{\circ} \mathrm{C} \text {. Subjects whose } \% \mathrm{BF} \\
\text { was } \geq 6.2 \text { maintained Tes in } 26^{\circ} \mathrm{C} \text { with } \\
\text { submaximal work. } \\
\text { This study shows that there is a temp } \\
\text { that is best for each person but for } \\
\text { leaner subjects it is higher than } 18 \text { - } \\
20^{\circ} \mathrm{C} \text {. }\end{array}$ & \\
\hline 31 & $\begin{array}{l}\text { Houston ME, } \\
\text { Christensen NJ, } \\
\text { Galbo H, Holst } \\
\text { JJ, Nielsen B, } \\
\text { Nygaard E, } \\
\text { Saltin B }\end{array}$ & $\begin{array}{l}\text { Metabolic responses to } \\
\text { swimming at three different } \\
\text { water temperatures. In } \\
\text { Eriksson B, Furberg E, eds. } \\
\text { Swimming Medicine IV. } \\
\text { University Park Press, } 1978 . \\
\text { Baltimore, 327-333 }\end{array}$ & $\begin{array}{l}\mathrm{N}=6 \text { male subjects swam in Tw @ } 21 \text {, } \\
27 \text { and } 33^{\circ} \mathrm{C} \text {, for } 1 \text { hour using } \\
\text { breaststroke at a speed that equated to } \\
65 \% \text { of their swimming } \mathrm{VO}_{2} \text { max. } \\
\mathrm{Tc} \text { and Tes tended to rise in Tw @ } \\
27^{\circ} \mathrm{C} \text { and decreased by the same } \\
\text { magnitude in Tw @ } 21^{\circ} \mathrm{C} \text {. Both Tc } \\
\text { and Tes rose in } 33^{\circ} \mathrm{C} \text { water. HRs for } \\
\text { swimming gradually increased over } \\
\text { time for Tw } 27 \text { and } 33^{\circ} \mathrm{C} \text { but were } \\
\text { lowest in Tw } 21^{\circ} \mathrm{C} \text {. Mean blood } \\
\text { lactate levels were highest in Tw } 21^{\circ} \mathrm{C} \\
\text { as was VO } \mathrm{O}_{2} \text { max. } \\
\text { Blood metabolites, plasma insulin, and } \\
\text { plasma levels of both noradrenaline } \\
\text { and adrenaline responses were typical } \\
\text { of other forms of submaximal exercise. } \\
\text { For competitive swimming the thermal } \\
\text { stress presented by } 21^{\circ} \mathrm{C} \text { could } \\
\text { augment training. However, for } \\
\text { recreational swimming, } 27^{\circ} \mathrm{C} \text { seems } \\
\text { most advisable for maintaining thermal } \\
\text { balance. }\end{array}$ & $2 \mathrm{a}$ \\
\hline 32 & $\begin{array}{l}\text { Isreal DJ, } \\
\text { Heyson KM, } \\
\text { Edlich RF, } \\
\text { Pozos RS, and } \\
\text { Wittmers LE }\end{array}$ & $\begin{array}{l}\text { Core temperature response } \\
\text { to immersed bicycle } \\
\text { ergometer exercise at water } \\
\text { temperatures of } 21^{\circ}, 25^{\circ}, \\
\text { and } 29^{\circ} \mathrm{C} \text {. Isreal DJ, Heyson } \\
\text { KM, Edlich RF, Pozos RS, } \\
\text { and Wittmers LE. J Burn } \\
\text { Care Rehabil 1989, Jul- } \\
\text { Aug;10(4):336-45 }\end{array}$ & $\begin{array}{l}\mathrm{N}=5 \text { male volunteers ( } \% \mathrm{BF} 14.8 \pm 5.6 \text { ) } \\
\text { were immersed to the neck at rest and } \\
\text { during exercise on a bicycle ergometer, } \\
\text { (predetermined exercise intensity: } \\
\left.63 \% \pm 0.6 \% \mathrm{~V}_{2} \text { max }\right) \text { for } 30 \text { minutes in } \\
\mathrm{Tw} @ 21,25 \text {, and } 29^{\circ} \mathrm{C} \text {. } \mathrm{V}_{2} \text { was } \\
\text { significantly higher during static } \\
\text { immersion in all Tws. Exercise } \mathrm{V}_{2} \mathrm{~S} \\
\text { for all conditions were statistically } \\
\text { similar except in } 21^{\circ} \mathrm{C} \text { where } \mathrm{V}_{2} \text { was } \\
3 \% \text { higher than in } 25^{\circ} \text { and } 29^{\circ} \mathrm{C} \text {. Tre } \\
\text { where significantly different with static }\end{array}$ & $2 \mathrm{a}$ \\
\hline
\end{tabular}




\begin{tabular}{|c|c|c|c|c|}
\hline & & & $\begin{array}{l}\text { immersion than for exercise immersion } \\
\text { in all Tws. Tre rose significantly in } \\
\text { Tw @ } 29^{\circ} \mathrm{C} \text {, there was little or no rise } \\
\text { at } 25^{\circ} \mathrm{C} \text { and a nonsignificant decrease } \\
\text { in } 21^{\circ} \mathrm{C} \text {. } \\
\text { Ts dropped in the first } 5 \text { minutes to } \\
\text { within } 1^{\circ} \mathrm{C} \text { of Tw in all immersion } \\
\text { conditions. A rating of thermal } \\
\text { comfort (RTC) designed by the authors } \\
\text { showed that during static immersion at } \\
\text { all Tws RTC paralleled Ts and did not } \\
\text { reflect changes in Tr. In Tw @ } 21^{\circ} \mathrm{C} \text {, } \\
\text { cycling caused an additional drop in } \\
\text { Ts. Subjects' perceptions of thermal } \\
\text { comfort may not accurately reflect Tr, } \\
\text { ie: people participating immersion } \\
\text { activities may not be aware that they } \\
\text { have hypothermia. } \\
\text { V0 } 0_{2} \text { during static conditions indicates } \\
\text { that subjects were shivering in the } \\
\text { colder water. RPE was not } \\
\text { significantly different between any of } \\
\text { the exercise conditions. } \\
\text { Despite the variation in } \% B F \text { the } \\
\text { temperature change patterns were } \\
\text { similar. }\end{array}$ & \\
\hline 33 & $\begin{array}{l}\text { Iwamoto J, } \\
\text { Sagawa S, } \\
\text { Tajima F, Miki } \\
\text { K, Shiraki K }\end{array}$ & $\begin{array}{l}\text { Critical water temperature } \\
\text { during water immersion at } \\
\text { various atmospheric } \\
\text { pressures. Iwamoto J, } \\
\text { Sagawa S, Tajima F, Miki K, } \\
\text { Shiraki K, J Appl Physiol., } \\
\text { 1988; 64(6): 2444-2448, }\end{array}$ & $\begin{array}{l}\text { Critical water temperature defined as } \\
\text { the lowest water temperature an } \\
\text { unprotected subject can tolerate at rest } \\
\text { for } 2 \text { hours without shivering. } \\
\text { Shivering was defined as } 10 \text { minutes of } \\
\text { visible tremor accompanied by more } \\
\text { than a } 15 \% \text { increase in } \mathrm{V}_{2} . \mathrm{N}=9 \\
\text { healthy males, ages } 23-36 \text { were } \\
\text { immersed at rest. Mean } \% \mathrm{BF} \text { was } 15.3 \\
\pm 1.2 \% \text {. Critical Temperature } \\
\text { established at } 0.6 \text { ATA was } 32 \pm \\
0.4^{\circ} \mathrm{C} \text {. }\end{array}$ & $2 \mathrm{a}$ \\
\hline 34 & $\begin{array}{l}\text { Jacobs I, Romet } \\
\text { T, Frim J, } \\
\text { Hynes A }\end{array}$ & $\begin{array}{l}\text { Effects of endurance fitness } \\
\text { on response to cold water } \\
\text { immersion. Jacobs I, Romet } \\
\text { T, Frim J, Hynes A. Aviat } \\
\text { Space Environ Med 1984; } \\
\end{array}$ & $\begin{array}{l}\mathrm{N}=9 \text { male volunteers donned standard } \\
\text { flight gear were immersed in } \\
\text { Tw@ } 10^{\circ} \mathrm{C} \text { with a lifejacket and } \\
\text { remained head out until the Tre } \\
\text { dropped } 1^{\circ} \mathrm{C} \text {. Immersion time ranged }\end{array}$ & $2 \mathrm{a}$ \\
\hline
\end{tabular}




\begin{tabular}{|c|c|c|c|c|}
\hline & & $55: 715-720$ & $\begin{array}{l}\text { from } 21-62 \text { minutes and was directly } \\
\text { related to \%BF. Metabolic values } \\
\text { ranged from } 1.969-5.110 \text { METs. The } \\
\text { length of time of immersion was } \\
\text { directly related to endurance fitness } \\
\text { level as determined by blood lactate } \\
\text { response to submaximal exercise. }\end{array}$ & \\
\hline 35 & Keatinge WR & $\begin{array}{l}\text { The effects of subcutaneous } \\
\text { fat and of previous exposure } \\
\text { to cold on the body } \\
\text { temperature, peripheral } \\
\text { blood flow and metabolic } \\
\text { rate of men in cold water. } \\
\text { Keatinge WR. J Physiol. } \\
\text { 1960; 153: } 166-178\end{array}$ & $\begin{array}{l}\mathrm{N}=12 \text { men, mean age } 20.3 \text { were } \\
\text { repeatedly immersed to the shoulder } \\
\text { for } 30 \text { minutes at a time in Tw @ } 15 \pm \\
0.1^{\circ} \mathrm{C} \text {. Tsk fell in the first } 2 \text { minutes to } \\
\text { within } 1^{\circ} \mathrm{C} \text { of Tw. The decrease in Tre } \\
\text { varied little in successive immersions } \\
\text { and was closely related to } \\
\text { subcutaneous fat thickness. In the last } \\
20 \text { minutes of immersion, the } \\
\text { metabolic rates of thin men increased } \\
\text { substantially over those of fat men. } \\
\text { Metabolic rate increased with exposure } \\
\text { to cold air prior to immersion. }\end{array}$ & $2 \mathrm{a}$ \\
\hline 36 & Keatinge WR & $\begin{array}{l}\text { The effect of work and } \\
\text { clothing on the maintenance } \\
\text { of the body temperature in } \\
\text { water. Keatinge WR. Q J } \\
\text { Exp Physiol 1961; 46: 69- } \\
82\end{array}$ & $\begin{array}{l}\mathrm{N}=12 \text { young naval ratings (ages 19- } \\
\text { 26) were immersed repeatedly to the } \\
\text { neck using } 4 \text { protocols in Tw @ } 5,15 \text {, } \\
25,35 \text {, and } 37.8^{\circ} \mathrm{C} .1 \text { ) clothed @ } \\
\text { work; } 2 \text { ) clothed, still; } 3 \text { ) unclothed } \\
\text { (wearing a cotton brief) @ work; 4) } \\
\text { unclothed, still. Immersion in the } \\
\text { higher temperatures were all unclothed. } \\
\text { Work consisted of a rowing motion (in } \\
\text { water rowing ergometer) at a standard } \\
\text { rate of } 22 \text { movements per minute or for } \\
\text { maximum rate, as rapidly as possible. } \\
\text { Clothing consisted of long woolen } \\
\text { pants a string vest, submariner's jersey, } \\
\text { arctic Jacket and trousers (kapok } \\
\text { lined), sea-boot stockings, half- } \\
\text { wellington rubber boots, mitts and a } \\
\text { leather helmet to protect the neck. } \\
\text { Results of } 20 \text { minute immersion in } \\
15^{\circ} \mathrm{C} \text { : mean Tsk was within } 0.6^{\circ} \mathrm{C} \text { of } \\
\text { Tw in unclothed, still and similar with } \\
\text { unclothed @ work. Tsk was } 5^{\circ} \mathrm{C} \\
\text { higher with clothed, still but not as } \\
\text { effective clothed, @ work. Tre fell }\end{array}$ & $2 \mathrm{a}$ \\
\hline
\end{tabular}




\begin{tabular}{|c|c|c|c|c|}
\hline & & & $\begin{array}{l}\text { twice as fast with work unclothed than } \\
\text { still. Clothing reduced the fall in Tre } \\
\text { both still and @ work. } \\
\text { Results of } 20 \text { minutes of immersion in } \\
\text { higher temperatures: Tsk were } \\
\text { dependent on Tw but were higher for } \\
@ \text { work than still protocols. Tre fell in } \\
\text { both } 25 \text { and } 35^{\circ} \mathrm{C} \text { with still protocols. } \\
\text { Work did not affect fall in mean Tb @ } \\
25^{\circ} \mathrm{C} \text { but reversed the small fall in } \\
\text { Tw@ } 35^{\circ} \mathrm{C} \text {. } \\
\text { In other experiments: N = } 12 \text { men } \\
\text { worked at their highest rate in Tw @ } \\
15^{\circ} \mathrm{C} \text {, Tre fell less than work at a } \\
\text { standard rate but still fell faster than } \\
\text { with the still protocol. } \\
\text { Tsk fell less regardless of } \\
\text { clothed/unclothed protocol in unstirred } \\
\text { water than in stirred water. } \\
\text { The major finding in this study was } \\
\text { that Tre fell with work in water below } \\
25^{\circ} \mathrm{C} \text {. Also, clothing gave a substantial } \\
\text { amount of protection when subjects } \\
\text { were still as opposed to exercise. }\end{array}$ & \\
\hline 37 & $\begin{array}{l}\text { Kenny GP, } \\
\text { Denis PM, } \\
\text { Proulx CE, } \\
\text { Giesbrecht GG }\end{array}$ & $\begin{array}{l}\text { The effect of dynamic } \\
\text { exercise on resting cold } \\
\text { thermoregulatory responses } \\
\text { measured during water } \\
\text { immersion. Kenny GP, } \\
\text { Denis PM, Proulx CE, } \\
\text { Giesbrecht GG. Eur J Appl } \\
\text { Physiol. 1999 79: 495-499 }\end{array}$ & $\begin{array}{l}\mathrm{N}=6 \text { males and } 1 \text { female, mean age } \\
24(3) \text { and } \% \mathrm{BF} 12.9(1.7) \% \text { immersed } \\
\text { at rest, to the clavicle at Tw } 37.5^{\circ} \mathrm{C} \text { and } \\
\text { cooled at a rate of } 6.5^{\circ} \mathrm{C} \text { per hour until } \\
\text { thresholds of vasoconstriction and } \\
\text { shivering were clearly established. } \\
\text { Onset of vasoconstriction was found to } \\
\text { be Tsk approx } 33^{\circ} \mathrm{C} \text {, Tes approx } 37^{\circ} \mathrm{C} \text {. } \\
\text { Onset of shivering was found to be Tsk } \\
\text { approx } 30.62^{\circ} \text { and Tes approx } 36.47^{\circ}\end{array}$ & $2 a$ \\
\hline 38 & $\begin{array}{l}\text { Kollias J, } \\
\text { Barlett 1, } \\
\text { Beigsteinova V, } \\
\text { Skinner JS, } \\
\text { Buskirk ER, } \\
\text { and Nicholas } \\
\text { WC }\end{array}$ & $\begin{array}{l}\text { Metabolic and thermal } \\
\text { responses of women during } \\
\text { cooling in water. Kollias J, } \\
\text { Barlett 1, Beigsteinova V, } \\
\text { Skinner JS, Buskirk ER, and } \\
\text { Nicholas WC, J Appl Physio } \\
\text { 1974. 36(5): 577-580 }\end{array}$ & $\begin{array}{l}\mathrm{N}=10 \text { college women }(3 \text { lean }-21- \\
24 \% \mathrm{BF} \text { and } 7 \text { obese }-29-41 \% \mathrm{BF}) \text { sat } \\
\text { immersed to the neck in } \mathrm{Tw} 20^{\circ} \mathrm{C} \text { for } \\
60 \text { minutes (limits: voluntary } \\
\text { withdraw or } 2^{\circ} \mathrm{C} \text { drop in core } \\
\text { temperature). Obese woman were } \\
\text { taller, } 53 \% \text { heavier, fatter and had a } \\
\text { lower surface area-to-mass ratio than } \\
\text { lean subjects. Within } 15 \text { minutes of } \\
\text { immersion metabolic rate for lean } \\
\text { subjects had increased } 2-3 \mathrm{X} \text {. Rate of }\end{array}$ & $2 \mathrm{a}$ \\
\hline
\end{tabular}




\begin{tabular}{|c|c|c|c|c|}
\hline & & & $\begin{array}{l}\Delta \text { Tre was greater for lean than for } \\
\text { obese. } \\
\text { Tre for obese rose ove the } 1^{\text {st }} 15 \mathrm{~min} \\
\text { and then slower declined. Tre for lean } \\
\text { subjects declined } 1.4^{\circ} \mathrm{C} \text { as compared to } \\
0.4^{\circ} \mathrm{C} \text { by obese subjects. } \\
\text { Also found that average Tre was lower } \\
\text { after participation }(\mathrm{N}=5) \text { in a weight } \\
\text { loss program, with decreases in } \mathrm{BW} \\
\text { btw } 3.7-6.7 \mathrm{~kg} \text {. }\end{array}$ & \\
\hline 39 & $\begin{array}{l}\text { Lapp MC, Gee } \\
\text { GK }\end{array}$ & $\begin{array}{l}\text { Human acclimatization to } \\
\text { cold water immersion. Lapp } \\
\text { MC, Gee GK. Arch Environ } \\
\text { Health } 196715 \text { (11): 568- } \\
579\end{array}$ & $\begin{array}{l}\mathrm{N}=8 \text { ( } 3 \text { male, } 5 \text { female) were } \\
\text { immersed at rest, } 2 \mathrm{X} / \mathrm{wk} \text { for } 1 \text { hour } \\
\text { over an } 8 \text { wk period @ selected bath } \\
\text { temperatures of } 21.1,23.3,25.6,27.8 \\
\text { and } 30^{\circ} \mathrm{C} \\
\text { The greater the body surface area the } \\
\text { greater the rate of body heat loss. } \\
\text { When bath temperatures ranged from } \\
30^{\circ} \mathrm{C}(86 \mathrm{~F}) \text { to } 28.3^{\circ} \mathrm{C}(83 \mathrm{~F}) \text {, subjects } \\
\text { did not mind the immersion } \\
\text { experience. } \\
\text { Shivering was observed for the first } \\
\text { time in water } @ 28.3^{\circ} \mathrm{C} \text { and generally } \\
\text { occurred after } 20-30 \text { minutes. } \\
\text { Shivering threshold for subjects in this } \\
\text { study was found to be established at a } \\
\text { differential of } 8.5^{\circ} \mathrm{C}(15.3 \mathrm{~F}) \text { between } \\
\text { Tre and Tw. } \\
\text { Temperatures from } 23.9^{\circ} \mathrm{C}(75 \mathrm{~F} \text { to } \\
21.1^{\circ} \mathrm{C}(70 \mathrm{~F}) \text { indicate a loss of } \\
\text { effectiveness of the thermoregulatory } \\
\text { mechanism. } \\
\text { Body surface area appeared to be a } \\
\text { significant factor in heat loss at this } \\
\text { temperature range. }\end{array}$ & $2 \mathrm{a}$ \\
\hline 40 & $\begin{array}{l}\text { LeBlanc J, Cote } \\
\text { J, Dulca S, and } \\
\text { Dulong-Turcot } \\
\text { F }\end{array}$ & $\begin{array}{l}\text { Effects of age, sex and } \\
\text { physical fitness on responses } \\
\text { to local cooling. LeBlanc J, } \\
\text { Cote J, Dulca S, and } \\
\text { Dulong-Turcot F. J Appl } \\
\text { Physiol 1978; 44: 813-817 }\end{array}$ & $\begin{array}{l}\text { This study aimed at explaining some of } \\
\text { the individual variability observed in } \\
\text { large groups of subjects. In all, three } \\
\text { experiments were carried out. } \mathrm{N}=27 \\
\text { males to assess the influence of fitness; } \\
\mathrm{N}=9 \text { subjects ( } 20-47 \mathrm{yrs} \text { ) and } 8 \text { ( } 53-60 \\
\text { yrs) to assess the influence of age; } \mathrm{N}= \\
9 \text { males (average age } 35.0) \text { and } 8 \\
\text { females (average age } 30.4) \text { to assess } \\
\text { the influence of gender. }\end{array}$ & $2 a$ \\
\hline
\end{tabular}




\begin{tabular}{|c|c|c|c|c|}
\hline & & & $\begin{array}{l}\text { All subjects were tested with a cold } \\
\text { hand test (placing the hand in water a } \\
5^{\circ} \mathrm{C} \text { for } 2 \text { minutes) and a cold face test } \\
\text { (cold wind, } 0^{\circ} \mathrm{C} \text { blown on the face at } \\
66 \mathrm{~km} \cdot \mathrm{h}^{-1} \text { ) } \\
\text { A significant relationship was found } \\
\text { between } \mathrm{VO}_{2 \text { max }} \text { and fall in Tsk. The } \\
\text { lower the } \mathrm{VO}_{2} \text { max, the larger the fall in } \\
\text { Tsk. HR increased during the cold } \\
\text { hand test but was significantly reduced } \\
\text { in subjects } 53-60 \text { compared to subjects } \\
20-40 . \text { No differences were found in } \\
\text { blood pressures between the two } \\
\text { groups. For the cold face test, } \\
\text { bradycardia was more pronounced for } \\
\text { older than younger subjects. } \\
\text { The gender experiment found that at } \\
\text { the beginning of the cold hand test, the } \\
\text { responses for men and women were } \\
\text { similar. At the end of the test, the } \\
\text { change in blood pressure was } \\
\text { significantly lower in women. } \\
\text { Bradycardia was similar for both in the } \\
\text { cold face test but during the } 2 \text { minutes } \\
\text { following the test, HRs of women } \\
\text { remained significantly lower than at } \\
\text { the beginning of the test compared to } \\
\text { men. Systolic BP returned to initial } \\
\text { levels following the cold hand test in } \\
\text { males but fell lower for women. }\end{array}$ & \\
\hline 41 & $\begin{array}{l}\text { Lee DT, Toner } \\
\text { MM, McArdle } \\
\text { WD, Vrabas IS, } \\
\text { Pandolf KB }\end{array}$ & $\begin{array}{l}\text { Thermal and metabolic } \\
\text { responses to cold-water } \\
\text { immersion at knee, hip and } \\
\text { shoulder levels. Lee DT, } \\
\text { Toner MM, McArdle WD, } \\
\text { Vrabas IS, Pandolf KB. J } \\
\text { Appl Physiol. 1997, 82(5): } \\
\text { 1523-1530 }\end{array}$ & $\begin{array}{l}\mathrm{N}=8 \text { men (mean age } 25 \text { yrs and } 16 \% \\
\mathrm{BF}) \text { were immersed at rest and during } \\
\text { leg cycling exercise }\left(35 \% \mathrm{~V}_{2} \text { max }\right) \text { in } \\
\text { knee, hip and shoulder levels in Tw } 15 \\
\text { and } 25^{\circ} \mathrm{C} \text { for up to } 135 \text { min (limits: } \\
\text { Tre } 35^{\circ} \mathrm{C} \text { or below or asked to be } \\
\text { removed). In this study cycling } \\
\text { exercise did not prevent Tre and Tes } \\
\text { from falling during immersion @ } 15^{\circ} \mathrm{C} \\
\text { in a depth greater than the knee. At } \\
\text { shoulder level immersion, in all } \\
\text { conditions, the combined fractional } \\
\text { values for thigh and trunk region } \\
\text { contributed btw } 59 \text { and } 66 \% \text { of total } \\
\text { body heat loss. The arms contributed }\end{array}$ & $2 \mathrm{a}$ \\
\hline
\end{tabular}




\begin{tabular}{|c|c|c|c|c|}
\hline & & & $\begin{array}{l}\text { not more than } 25 \% \text { of heat loss values. } \\
\text { This level of exercise did not maintain } \\
\text { Tre at baseline levels in shoulder level } \\
\text { immersion@ Tw } 25^{\circ} \mathrm{C} \text {. }\end{array}$ & \\
\hline 42 & $\begin{array}{l}\text { McArdle WD, } \\
\text { Magel JR, } \\
\text { Gerley TJ, } \\
\text { Toner MM }\end{array}$ & $\begin{array}{l}\text { Thermal adjustement to } \\
\text { cold-water exposure in } \\
\text { resting men and women. } \\
\text { McArdle WD, Magel JR, } \\
\text { Gerley TJ, Toner, MM. J } \\
\text { Apply Phsiol: Respirat } \\
\text { Environ Exercise Physiol } \\
\text { 1984. 56(6) 1565-1571 }\end{array}$ & $\begin{array}{l}\mathrm{N}=18 \text { ( } 10 \text { men and } 8 \text { women of } \\
\text { college age) were immersed to the } \\
\text { level of the first thoracic vertebrae for } \\
1 \text { hour @ Tw } 20,24 \text {,and } 28^{\circ} \mathrm{C} \text {. } \\
\text { Fat subjects experienced a } \\
\text { proportionately smaller metabolic, } \\
\text { thermal and cardiovascular response to } \\
\text { cold-water immersion in comparison to } \\
\text { leaner counterparts. } \\
\text { For men btw } 15-18 \% \mathrm{BF} \text {, Tre was } \\
\text { maintained at pre-immersion levels } \\
\text { during the first } 10-20 \text { min of rest at all } \\
\text { Tw, and then dropped steadily. } \\
\text { For women of average BF }(24-27 \%) \text {, } \\
\text { Tre deviated only slightly during the } \\
\text { first } 20 \text { minutes of rest at all Tw. } \\
\text { Thereafter Tre steadily decreased with } \\
\text { largest reductions @ } 24 \text { and } 20^{\circ} \mathrm{C} \text {. }\end{array}$ & $2 \mathrm{a}$ \\
\hline 43 & $\begin{array}{l}\text { McArdle WD, } \\
\text { Toner MM, } \\
\text { Magel JR, } \\
\text { Spina RJ, and } \\
\text { Pandolf KB }\end{array}$ & $\begin{array}{l}\text { Thermal responses of men } \\
\text { and women during cold } \\
\text { water immersion: influence } \\
\text { of exercise intesity. } \\
\text { McArdle WD, Toner MM, } \\
\text { Magel JR, Spina RJ, and } \\
\text { Pandolf KB. Eur J Appl } \\
\text { Physiol 1992. 65: } 265-270\end{array}$ & $\begin{array}{l}\mathrm{N}=16,8 \text { men }(8-18 \% \mathrm{BF}) \text { and } 8 \\
\text { women }(15-29 \%) \text { were immersed to } \\
\text { the level of the first thoracic vertebrae } \\
\text { for } 1 \text { hour while performing arm-leg } \\
\text { exercise at } 3 \text { different } \mathrm{V}_{2} \text { levels. For } \\
\text { men these equated to } 20,36 \& 49 \% \\
\mathrm{VO}_{2 \text { max. }} \text { For women these equated to } \\
27,48 \text {, and } 66 \% \mathrm{VO}_{2 \mathrm{max}} \text {. For women } \\
\text { at rest and } 27 \% \text { intensity, Tre declined } \\
\text { @ Tw } 20 \text { and } 28^{\circ} \mathrm{C} \text {. Women } \\
\text { maintained a higher Tre } @ \text { exercise II } \\
\text { and III especially in cold water. At } \\
28^{\circ} \mathrm{C} \text { women had only a slight decrease } \\
\text { in Tre with level II exercise and an } \\
\text { increase in Tre with level III exercise } \\
\left(66^{\circ} \% \text { intensity). }\right. \\
\text { Tre for men declined at all three levels } \\
\text { of intensity for both } 20 \text { and } 28^{\circ} \mathrm{C} \\
\text { In } 20^{\circ} \mathrm{C} \text { water an exercise intensity of } \\
\text { about } 1.211 / \text { min }^{1} \text { and higher was } \\
\text { sufficient to maintain Tre at near pre- } \\
\text { immersion values. }\end{array}$ & $2 \mathrm{a}$ \\
\hline 44 & McMurray RG, & Thermoregulation in & This study was conducted to compare & $a$ \\
\hline
\end{tabular}




\begin{tabular}{|c|c|c|c|c|}
\hline & Horvath SM & $\begin{array}{l}\text { swimmers and runners. } \\
\text { McMurray RG, Horvath SM. } \\
\text { J Appl Physiol: Respirat } \\
\text { Environ Exercise Physiol } \\
\text { 1979. 46(6): 1086-1092 }\end{array}$ & $\begin{array}{l}\text { thermoregulatory responses of trained } \\
\text { runners (age } 20.8 \pm 1.1 \text { and } \% \mathrm{BF} \\
7.4 \pm 0.9 \text { ) and swimmers (age } 18.5 \pm 0.5 \\
\text { and } \% \mathrm{BF} 9.9 \pm 1.2 \text { ) performing } \\
\text { moderate exercise (cycle ergometer) in } \\
\text { water } @ 20,25,30 \text {, and } 35^{\circ} \mathrm{C} . \mathrm{N}=11 \text {, } \\
6 \text { swimmers and } 5 \text { runners, immersed } \\
\text { to the neck and exercising at } 60 \% \text { (pre- } \\
\text { determined) } 0_{2} \text { max for } 30 \text { minutes. } \\
\text { Runners and swimmers had similar HR } \\
@ \text { any given Tw. HR increased with } \\
\text { increased Tw with a significant } \\
\text { increase } @ 30 \text { and } 35^{\circ} \mathrm{C} \text {. Heat } \\
\text { production increased in both groups } @ \\
\text { Tw } 30 \text { and } 35^{\circ} \mathrm{C} . \\
\text { During work in } 20^{\circ} \mathrm{C} \text { water, runners } \\
\text { experienced a negative ( }-8 \pm 2 \text { kcal) } \\
\text { heat balance. Swimmers had a positive } \\
\text { (13 } \pm 7 \text { ) heat storage. } \\
\text { Tre for both swimmers and runners } \\
\text { increased in Tw above } 20^{\circ} \mathrm{C} \\
\text { An optimal temperature for } \\
\text { performance can be described as the } \\
\text { temperature at which the change in } \\
\text { caloric cost is least for a given } \\
\text { workload. Optimal Tw for runners was } \\
\text { approximately } 30^{\circ} \mathrm{C} \text { and for swimmers, } \\
\text { approximately } 25^{\circ} \mathrm{C} \text {. }\end{array}$ & \\
\hline 45 & $\begin{array}{l}\text { Moore TO, } \\
\text { Bernauer EM, } \\
\text { Set G, Park YS, } \\
\text { Hong SK, } \\
\text { Hayashi EM }\end{array}$ & $\begin{array}{l}\text { Effect of immersion at } \\
\text { different water temperatures } \\
\text { on graded exercise } \\
\text { performance in man. Moore } \\
\text { To, Bernauer EM, Set G, } \\
\text { Park YS, Hong SK, Hayashi } \\
\text { EM. Aerosp Med 1970; } \\
\text { 41(12): } 1404-1408\end{array}$ & $\begin{array}{l}\text { This study compared work at three } \\
\text { different rates in Ta @ } 23-25^{\circ} \mathrm{C} \text { and } \\
\text { submerged with SCUBA in } 4 \text { feet of } \\
\text { water in Tw @ } 16,22,30^{\circ} \mathrm{C} . \mathrm{N}=8 \\
\text { healthy adult males (mean age } 32.2 \text { yrs } \\
\text { and \%BF } 18.0 \pm 3.2 \text { ) underwent } 3 \text { work } \\
\text { trials (light, moderate and heavy and } \\
\text { forced exercise restricted to legs only) } \\
\text { in air and three work trials in each of } \\
\text { the recorded Tws. ( } 5 \text { min rest, } 5 \text { minute } \\
\text { work }+3 \text { min rest for light, moderate } \\
\text { and heavy with no rest from heavy to } \\
\text { forced exercise) approximately } 30 \text { min. } \\
\text { At rest VO }{ }_{2} \text { was generally higher than } \\
\text { in air especially at } 16 \text { and } 22^{\circ} \mathrm{C} \text {. At the } \\
\text { highest work level, } \mathrm{VO}_{2} \text { was } \\
\text { approximately } 75 \% \text { of predicted max }\end{array}$ & $\begin{array}{c}2 \mathrm{a} \\
2 \mathrm{aE}\end{array}$ \\
\hline
\end{tabular}




\begin{tabular}{|c|c|c|c|c|}
\hline & & & $\begin{array}{l}\text { Tre did not change significantly in air } \\
\text { or in Tw @ } 30 \text { and } 16^{\circ} \mathrm{C} \text {. At Tw } 22^{\circ} \mathrm{C} \text {, } \\
\text { one subject }(\% \mathrm{BF} 9.5) \text { experienced a } \\
\text { progressive decline in Tre. } \\
\text { There was a significantly lower HR at } \\
\text { high workloads in water as compared } \\
\text { to air. At rest, subjects experienced } \\
\text { bradycardia upon initial immersion but } \\
\text { HR returned to steady state resting by } \\
\text { the end of the trial. } \\
\text { This significance of this study is affect } \\
\text { of the different modes of exercise on } \\
\text { Tre. Leg exercise generally maintained } \\
\text { Tre at all workloads in all three } \\
\text { temperatures. }\end{array}$ & \\
\hline 46 & $\begin{array}{l}\text { Mougios V, } \\
\text { Deligiannis A. }\end{array}$ & $\begin{array}{l}\text { Effect of water temperature } \\
\text { on performance, lactate } \\
\text { production and heart rate at } \\
\text { swimming of maximal and } \\
\text { submaximal intensity. } \\
\text { Mougios V, Deligiannis A. } \\
\text { The Journal of Sports } \\
\text { Medicine and Physical } \\
\text { Fitness } 1993 \text { 33(1): } 27-22\end{array}$ & $\begin{array}{l}\mathrm{N}=30 \text { ( } 15 \text { male sprinters and } 15 \text { male } \\
\text { endurance trained swimmers) Sprinters } \\
\text { swam } 100 \mathrm{M} \text {. Endurance swimmers } \\
\text { swam for } 30 \text { minutes at water } \\
\text { temperatures of } 20,26 \text { and } 32^{\circ} \mathrm{C} \text {. The } \\
\text { subjects characteristics (age } 16.4 \pm 0.9 \\
\text { and } \% \mathrm{BF} 16.0 \pm 2.3 \text { ). Each swimmer did } \\
1 \text { single effort in each temp ( } 5 \\
\text { swimmers in each water temp). } \\
\text { All results are compared to a test swim } \\
\text { at } 26^{\circ} \mathrm{C} \text { : For Sprinters, } \mathrm{HR} \text { was } \\
\text { significantly higher in } 32^{\circ} \mathrm{C} \text { and } \\
\text { significantly lower in } 20^{\circ} \mathrm{C} \text {. } \\
\text { For endurance swimmers, HRs rose } \\
\text { rapidly in } 26 \text { and } 32^{\circ} \mathrm{C} \text { and remained } \\
\text { fairly constant but continued to rise in } \\
20^{\circ} \mathrm{C} \text { for } 20 \text { min and exceeded values } \\
\text { in } 26^{\circ} \mathrm{C} \text {. } \\
\text { There was an observed increase in } \\
\text { speed with an increase in water } \\
\text { temperature. Based on these findings, } \\
\text { we suggest that water temperature is a } \\
\text { primary factor in determining the work } \\
\text { rate of swimmers. }\end{array}$ & $2 a$ \\
\hline 47 & $\begin{array}{l}\text { Nadel ER, } \\
\text { Holmer I, Bergh } \\
\text { U, Astrand PO, } \\
\text { Stolwijk JAJ }\end{array}$ & $\begin{array}{l}\text { Energy exchanges in } \\
\text { swimming man. Nadel ER, } \\
\text { Holmer I, Bergh U, Astrand } \\
\text { PO, Stolwijk JAJ. J Appl }\end{array}$ & $\begin{array}{l}\mathrm{N}=3 \text { at rest or swimming breaststroke } \\
\text { in three water temperatures }\left(18^{\circ}, 26^{\circ}\right. \\
\left.\text { and } 33^{\circ}\right) \text { at water velocities chosen to } \\
\text { elicit } 40 \%, 70 \% \text { and } 100 \% \mathrm{VO}_{2} \max \end{array}$ & $2 \mathrm{a}$ \\
\hline
\end{tabular}




\begin{tabular}{|c|c|c|c|c|}
\hline & & $\begin{array}{l}\text { Physiol. } 1974 \text { 36(4): } 465- \\
471\end{array}$ & $\begin{array}{l}\text { (these were different for each subject) } \\
\text { Tb changes after } 20 \text { minutes were } \\
\text { related to Tw, swimming intensity and } \\
\text { body insulation. } \\
\text { @ } 40 \% \text { effort internal temperatures fell } \\
\text { in } 18 \text { and } 26^{\circ} \mathrm{C} \text { (inversely related to the } \\
\text { degree of insulation and greater in } \\
\text { leaner subjects). In } 33^{\circ} \mathrm{C} \text { all subjects } \\
\text { experienced increased internal temps. } \\
@ 70 \% \text { effort - internal temps } \\
\text { increased in } 26 \text { and } 33^{\circ} \mathrm{C} \text {. Lean } \\
\text { subjects had a decrease in Tes at } 18^{\circ} \mathrm{C} \text {. } \\
\text { All swimmers maintained internal } \\
\text { temperatures in all Tw at Maximal } \\
\text { effort. } \\
\text { For most swimmers, the optimal Tw } \\
\text { for maximal swimming performances } \\
\text { in sprints would be around } 28-30^{\circ} \mathrm{C} \text {, } \\
\text { where little heat would be stored and } \\
\text { performance would not be impaired. }\end{array}$ & \\
\hline 48 & $\begin{array}{l}\text { Nielsen B, } \\
\text { Davies CTM }\end{array}$ & $\begin{array}{l}\text { Temperature regulation } \\
\text { during exercise in water and } \\
\text { air. Nielsen B, Davies CTM. } \\
\text { Acta Physiol Scand. 1976, } \\
\text { 98. 500-508 }\end{array}$ & $\begin{array}{l}\mathrm{N}=4 \text { subjects swam breaststroke at two } \\
\text { different workloads }(\approx 49 \text { and } 60 \%) \text { at a } \\
\text { constant pace which they could } \\
\text { maintain for } 1 \text { hour in water } @ 30^{\circ} \text { or } \\
33^{\circ} \mathrm{C} \text {. The results of these experiments } \\
\text { were compared to same subject } \\
\text { exercise under the same conditions in } \\
\text { air on a bicycle ergometer. The results } \\
\text { showed that for a given work load and } \\
\text { Ts, Tes and Tre were about } 0.04^{\circ} \mathrm{C} \\
\text { lower and conductance values }(K) \text { were } \\
\text { higher in swimming than cycling. } \\
\text { Tre increased at both workloads in both } \\
\text { temperatures. }\end{array}$ & $2 \mathrm{a}$ \\
\hline 49 & $\begin{array}{l}\text { Park YS, } \\
\text { Pendergast DR, } \\
\text { Rennie DW }\end{array}$ & $\begin{array}{l}\text { Decrease in body insulation } \\
\text { with exercise in cool water. } \\
\text { Park YS, Pendergast DR, } \\
\text { Rennie DW. Undersea } \\
\text { Biomed Res 1984; 11(2): } \\
\text { 159-168 }\end{array}$ & $\begin{array}{l}\text { This study was an attempt to quantify } \\
\text { the relative insulative value of } \\
\text { subcutaneous fat vs muscle during } \\
\text { prolonged immersion (chin deep) in } \\
\text { water } 28-32^{\circ} \mathrm{C} \text { (established Tcw for } \\
\text { each subject). } \mathrm{N}=7 \mathrm{immersed} \text { at rest } \\
\text { and with } 2 \text { levels of arm-leg exercise) } \\
\text { for } 3 \text { hours. At rest Tre dropped } \\
\text { exponentially over the } 3 \mathrm{hr} \text { period. } \\
\text { With light exercise }\left(73 \mathrm{kcal} \bullet \mathrm{m}^{2} \bullet \mathrm{h}^{1} \text { ), }\right. \\
\text { observations were similar to rest. With }\end{array}$ & $2 \mathrm{a}$ \\
\hline
\end{tabular}


ARC SAC Water Temperature and ARC Aquatic Courses Scientific Review

\begin{tabular}{|c|c|c|c|c|}
\hline & & & $\begin{array}{l}\text { moderate exercise }\left(120 \mathrm{kcal} \cdot \mathrm{m}^{2} \cdot \mathrm{h}^{1}\right) \\
\text { there were no significant changes in } \\
\text { Tre. }\end{array}$ & \\
\hline 50 & $\begin{array}{l}\text { Pirnay G, } \\
\text { Deroanne R, } \\
\text { and Petit JM }\end{array}$ & $\begin{array}{l}\text { Influence of water } \\
\text { temperature on thermal, } \\
\text { circulatory and respiratory } \\
\text { responses to muscular work. } \\
\text { Pirnay G, Deroanne R, and } \\
\text { Petit JM, Europ J Appl } \\
\text { Physiol, } 1977 ; 37: 129-136\end{array}$ & $\begin{array}{l}\mathrm{N}=5 \text { medical students were immersed, } \\
\text { head-out, on a bicycle ergometer in Tw } \\
\text { which was modified from } 20 \text { to } 40^{\circ} \mathrm{C} \text {. } \\
\text { They participated in } 2 \text { submaximal } \\
\text { (efforts approximately } 1 / 3 \text { and } 2 / 3 \text { of } \\
\left.\mathrm{V}_{2} \text { max }\right) \text { and } 1 \text { maximal test. Warm } \\
\text { water }\left(\geq 30^{\circ} \mathrm{C}\right) \text { at both submaximal } \\
\text { intensities caused hyperthermia. } 20^{\circ} \mathrm{C} \\
\text { cold water accelerates heat exchanges } \\
\text { between the body and water. Tre was } \\
\text { always lower in these conditions but } \\
\text { thermal balance was maintained in } \\
20^{\circ} \mathrm{C} \text { with } \approx 50 \% \text { intensity. } \\
\text { Muscle temp was always higher than } \\
\text { Tre, decreasing in cold and increasing } \\
\text { in warm water. Maximal } \mathrm{O}_{2} \\
\text { consumption varied with Tw. In water } \\
\text { @ } 20^{\circ} \mathrm{C} \text {, the aerobic capacity was low } \\
\text { for all subjects. With an increase in } \\
\text { Tw, maximal } \mathrm{O}_{2} \text { consumption showed } \\
\text { a significant increase. Between } 25^{\circ} \\
\text { and } 35^{\circ} \mathrm{C} \text { the rise was moderate and } \\
\text { nonsignificant. In very warm }\left(40^{\circ} \mathrm{C}\right) \\
\text { water, maximum } \mathrm{O}_{2} \text { consumption } \\
\text { decreased for all subjects. } \\
\text { These results indicate that performance } \\
\text { is affected water temperature extremes. }\end{array}$ & $2 \mathrm{a}$ \\
\hline 51 & $\begin{array}{l}\text { Pretorius T, } \\
\text { Bristow GK, } \\
\text { Steinman AM, } \\
\text { Giesbrecht GG }\end{array}$ & $\begin{array}{l}\text { Thermal effects of whole } \\
\text { head submersion in cold } \\
\text { water on nonshivering } \\
\text { humans. Pretorius T, } \\
\text { Bristow GK, Steinman AM, } \\
\text { Giesbrecht GG. J Appl } \\
\text { Physiol 2006, 101: 699-675 }\end{array}$ & $\begin{array}{l}\mathrm{N}=8 \text { health male subjects studied in } \\
17^{\circ} \mathrm{C} \text { water under } 4 \text { conditions: body } \\
\text { insulated (dry suit, no hood) with head } \\
\text { out or completely submerged, body } \\
\text { uninsulated (exposed) with head above } \\
\text { or completely submerged. } \\
\text { Results analyzed the first } 30 \text { minutes of } \\
\text { immersion / submersion. Tes } \\
\text { decreased significantly after } 15 \\
\text { minutes in all conditions. Tes was } \\
\text { lower in the head in (submersion) } \\
\text { condition then for head-out condition } \\
\text { from } 15 \text { minutes onward. There were } \\
\text { no differences btw body insulated, } \\
\text { head-in and body exposed, head-out }\end{array}$ & $2 \mathrm{a}$ \\
\hline
\end{tabular}




\begin{tabular}{|c|c|c|c|c|}
\hline & & & $\begin{array}{l}\text { conditions throughout the experiment. } \\
\text { The head ( } 7 \% \text { of the total body surface } \\
\text { area) contributed only } 10 \% \text { to the total } \\
\text { heat loss. Head submersion increased } \\
\text { core cooling rate much more (average } \\
\text { of } 42 \%) \text { than it increased total heat } \\
\text { loss. }\end{array}$ & \\
\hline 52 & $\begin{array}{l}\text { Pretorius T, } \\
\text { Cahill R, Kocay } \\
\text { S, and } \\
\text { Giesbrecht GG }\end{array}$ & $\begin{array}{l}\text { Shivering heat production } \\
\text { and core cooling during } \\
\text { head-in and head-out } \\
\text { immersion in } 17^{\circ} \mathrm{C} \text { Water. } \\
\text { Pretorius T, Farrell C, Kocay } \\
\text { S, and Giesbrecht GG 2008, } \\
\text { Aviat Space Environ Med; } \\
79: 495-499\end{array}$ & $\begin{array}{l}\mathrm{N}=8 \text { male subjects } \\
\text { immersed/submersed in Tw } @ 17^{\circ} \mathrm{C} \\
\text { under } 4 \text { conditions: 1) exposed head- } \\
\text { out, 2) exposed head-in, 3) insulated } \\
\text { head-out, 4) insulated head-in for a } \\
\text { period not longer than } 60 \text { minutes } \\
\text { (statistics reported on } 45 \text { minutes) } \\
\text { Tes was unchanged throughout } \\
\text { insulated trials - differences in Tes } \\
\text { were not significant between insulated } \\
\text { head-in and exposed head-out. } \\
\text { Total body heat loss was more than } \\
\text { twice the amount in the exposed than } \\
\text { in the insulated conditions. Head } \\
\text { submersion caused a fourfold increase } \\
\text { in head heat loss in both exposed and } \\
\text { insulated conditions. In the exposed } \\
\text { head-in condition, head heat loss } \\
\text { accounted for } 11 \% \text { of total cutaneous } \\
\text { heat loss (as compared to the head } \\
\text { being only } 7 \% \text { of the total body surface } \\
\text { area). }\end{array}$ & $2 \mathrm{a}$ \\
\hline 53 & $\begin{array}{l}\text { Prisby R, } \\
\text { Glickman- } \\
\text { Weiss EL, } \\
\text { Nelson AG, } \\
\text { Caine N }\end{array}$ & $\begin{array}{l}\text { Thermal and metabolic } \\
\text { responses of high and low } \\
\text { fat women to cold water } \\
\text { immersion. Prisby R, } \\
\text { Glickman-Weiss EL, Nelson } \\
\text { AG, Caine N. Aviat Space } \\
\text { Enbiron Med 1999, 70:887- } \\
891\end{array}$ & $\begin{array}{l}\mathrm{N}=12 \text { females ages } 18-35 \text { ( } 6 \mathrm{HF} \text { ie; } \\
28-35 \% \mathrm{BF} \text { and } 6 \mathrm{LF} \text { ie; } 15-22 \% \mathrm{BF}) \\
\text { experienced } 2 \text { hours of immersion in } \\
17 \text { and } 27^{\circ} \mathrm{C} \text {. At } 17^{\circ} \mathrm{C} \text {, Tre declined in } \\
\text { both groups across time. At minutes } \\
105 \text { and } 120 \text { there was a significant } \\
\text { difference in Tre between groups. Tsk } \\
\text { declined over the first } 15 \text { minutes and } \\
\text { remained steady for the } 120 \text { minutes. } \\
\text { Tissue insulation (Ti) increased and } \\
\text { Tsk decreased significantly across time } \\
\text { but there were no significant } \\
\text { differences for variables Ti, } 0_{2} \text { and } \\
\text { Tsk. }\end{array}$ & $2 \mathrm{a}$ \\
\hline 54 & Pugh LGC, & The physiology of channel & A three year study of channel & $2 \mathrm{a}$ \\
\hline
\end{tabular}




\begin{tabular}{|c|c|c|c|c|}
\hline & Edholm OG & $\begin{array}{l}\text { swimmers. Pugh LGC, } \\
\text { Edholm OG. 1955. The } \\
\text { Lancet Oct } 8,761-768\end{array}$ & $\begin{array}{l}\text { swimmers }(\mathrm{N}=5) \text { ages } 21-42 \text {, } \\
\text { immersion time ranging from } 12-20 \\
\text { hours is water @ } 15.5^{\circ} \mathrm{C}(60 \mathrm{~F}) \text {. } \\
\text { Subjects conformed to a certain } \\
\text { specific physical type (SA } 1.78 \mathrm{~m}^{2}- \\
\left.2.04 \mathrm{~m}^{2}\right) \text {. For thinner subjects, } \\
\text { metabolism of swimming was } \\
\text { insufficient to prevent hypothermia } \\
\text { from developing } @ 21.8^{\circ} \mathrm{C}(71.2 \mathrm{~F}) \text {. } \\
25^{\circ} \mathrm{C}(77 \mathrm{~F}) \text { was necessary for a stable } \\
\text { state. These findings suggest that } \\
\text { tolerance of cold water is related to the } \\
\text { thickness of subcutaneous fat. }\end{array}$ & \\
\hline 55 & $\begin{array}{l}\text { Rennie DW, } \\
\text { Covino BG, } \\
\text { Howell BJ, } \\
\text { Song SH, Kang } \\
\text { BS, and Hong } \\
\text { SK }\end{array}$ & $\begin{array}{l}\text { Physical insulation of } \\
\text { Korean diving women. } \\
\text { Rennie DW, Covino BG, } \\
\text { Howell BJ, Song SH, Kang } \\
\text { BS, and Hong SK. J Appl } \\
\text { Physiol. } 1962 \text { 17(6): 961- } \\
966\end{array}$ & $\begin{array}{l}\text { Human cold adaptation was studied by } \\
\text { comparing body insulation with } 9 \\
\text { Korean diving women, } 7 \text { non diving } \\
\text { Korean women }(12 \% \mathrm{BF}), 7 \text { Korean } \\
\text { men }(10 \% \mathrm{BF}), 10 \text { American women } \\
\text { and } 10 \text { American men of various } \\
\text { adiposity }(16 \% \mathrm{BF}) \text {. Subjects were } \\
\text { submerged supine for } 3 \text { hours with just } \\
\text { the face showing in water } @ \text { Critical } \\
\text { water temperature (between } 30 \text { and } \\
\left.34^{\circ} \mathrm{C}\right) \text {. } \\
\text { Tcw for Americans with less than } 16^{\circ} \% \\
\mathrm{BF} \approx 33-34^{\circ} \mathrm{C} . \text { For more obese } \\
\text { Americans it was } \approx 30^{\circ} \mathrm{C} \text {. } \\
\text { Korean men }(10 \% \mathrm{BF}) \mathrm{Tcw} \approx 33-31^{\circ} \mathrm{C} \text {. } \\
\text { For Korean women }(12 \% \mathrm{BF}) \text { Tcw } \approx \\
31-30^{\circ} \mathrm{C} \text { and lower. } \\
\text { There were no differences in maximal } \\
\text { tissue insulation between Korean men } \\
\text { and women that could not be accounted } \\
\text { for by differences in subcutaneous fat. } \\
\text { American tissue insulation is less than } \\
\text { the Korean when the two are compared } \\
\text { at equal fat thicknesses. }\end{array}$ & $2 \mathrm{a}$ \\
\hline 56 & $\begin{array}{l}\text { Robinson S, } \\
\text { Somers A }\end{array}$ & $\begin{array}{l}\text { Temperature regulation in } \\
\text { swimming. Robinson S, } \\
\text { Somers A. J Physiol Paris } \\
\text { 1971. 63: 406-409 }\end{array}$ & $\begin{array}{l}\text { Runners and swimmers were compared } \\
\text { at the same metabolic rate. N=6 } \\
\text { swimmers age } 20-24 \text {, swam freestyle } \\
\text { for } 60 \text { minutes in water @ } 21,29 \text {, and } \\
33.5^{\circ} \mathrm{C} \text {. The data in this study indicate } \\
\text { that optimal water temperature for } \\
\text { competitive swimming@ distances } \\
\text { requiring up to } 20 \text { minutes must be }\end{array}$ & $2 \mathrm{a}$ \\
\hline
\end{tabular}




\begin{tabular}{|c|c|c|c|c|}
\hline & & & $\begin{array}{l}\text { between } 21^{\circ} \text { and } 33^{\circ} \mathrm{C} . @ 21^{\circ} \mathrm{C} \text { the } \\
\text { average Tre of the slowest swimmers } \\
\text { declined. The average Tre of the } \\
\text { fastest swimmers rose slightly. } \\
\text { Optimal Tw may be nearer } 29^{\circ} \mathrm{C} \text { since } \\
\text { at that temperature these swimmers } \\
\text { central (core) to surface (sk) } \\
\text { temperature gradient were adequate for } \\
\text { heat conductance. }\end{array}$ & \\
\hline 57 & $\begin{array}{l}\text { Sagawa S, } \\
\text { Shiraki K, } \\
\text { Yousef MK, } \\
\text { and Konda N }\end{array}$ & $\begin{array}{l}\text { Water temperature and } \\
\text { intensity of exercise in } \\
\text { maintenance of thermal } \\
\text { equilibrium. Sagawa S, } \\
\text { Shiraki K, Yousef MK, and } \\
\text { Konda N. J Appl Physiol } \\
\text { 1988, 65(6): } 2413-2419\end{array}$ & $\begin{array}{l}\mathrm{N}=6 \text { men immersed to the neck for } 1 \\
\text { hour in } 4 \text { water temperatures } \\
\text { Mean Tcw }=31.2 \pm 0.5^{\circ} \mathrm{C} \\
\mathrm{Ttn}=34^{\circ} \mathrm{C} \\
\mathrm{Atn}=36^{\circ} \mathrm{C} \\
\text { Mean Btn }=\mathrm{Tcw}-2^{\circ} \mathrm{C} \text { or } \approx 28.2^{\circ} \mathrm{C} \\
\text { They performed leg exercise at } 2,3 \text {, } \\
\text { and } 4 \text { METs. } \\
\text { Resting metabolism was significantly } \\
\text { higher in water below Tcw due to } \\
\text { shivering. Metabolic rate was the same } \\
\text { regardless of Tw. Resting heat loss } \\
\text { was greater in the limbs than the trunk. } \\
\text { In this study leg exercise caused an } \\
\text { increase in Tre compared to rest in all } \\
\text { temperatures. LE @ } 3-4 \text { METS was } \\
\text { effective in maintaining near normal } \\
\text { core temperatures in water @ Tcw - } \\
2^{\circ} \mathrm{C} \text {. Two METs was enough to } \\
\text { maintain near normal core } \\
\text { temperatures @ Tcw. Calculations } \\
\text { indicate that a Tw of approximately } \\
25^{\circ} \mathrm{C} \text { may be the lowest Tw in which } \\
\text { the average unprotected man can } \\
\text { continue exercising without a decrease } \\
\text { in Tc (ie: crucial Tw for unprotected } \\
\text { exercising man). }\end{array}$ & $2 \mathrm{a}$ \\
\hline 58 & $\begin{array}{l}\text { Shimizu T, } \\
\text { Kosaka M, } \\
\text { Fujishima K }\end{array}$ & $\begin{array}{l}\text { Human thermoregulatory } \\
\text { responses during prolonged } \\
\text { walking in water@ } 25,30 \text {, } \\
\text { and } 35^{\circ} \mathrm{C} \text {. Shimizu T, } \\
\text { Kosaka M, Fujishima K. } \\
\text { Euro J App Physiol 1998; } \\
\text { 78: 473-478 }\end{array}$ & $\begin{array}{l}\mathrm{N}=8 \text { students(age } 18-20 \text { and } \\
\% \mathrm{BF} \approx 12 \% \text { ), immersed to the xyphoid } \\
\text { process performed treadmill walking } \\
\text { for } 60 \text { minutes } @ 50 \% \mathrm{~V}_{2} \text { max at three } \\
\text { different temperatures. There were no } \\
\text { significant differences in Tre observed } \\
\text { during exercise in water at different } \\
\text { temperatures. Tre increased in all } \\
\text { temperatures with walking. Tsk of }\end{array}$ & $2 \mathrm{a}$ \\
\hline
\end{tabular}




\begin{tabular}{|c|c|c|c|c|}
\hline & & & $\begin{array}{l}\text { immersed skin was directly determined } \\
\text { by } \mathrm{Tw} \text {. There were identical increases } \\
\text { in } \mathrm{V}_{2} \text { at identical intensities which } \\
\text { infers that there was no additional } \\
\text { demand for thermoregulatory heat } \\
\text { production generated by the lowest } \\
\text { compared to the higher Tw. }\end{array}$ & \\
\hline 59 & $\begin{array}{l}\text { Sloan REG, } \\
\text { Keatinge WR, }\end{array}$ & $\begin{array}{l}\text { Cooling rates of young } \\
\text { people swimming in cold } \\
\text { water. Sloan REG, Keatinge } \\
\text { WR. J Appl Physiol. 1973; } \\
\text { 35(3): } 371-375\end{array}$ & $\begin{array}{l}\mathrm{N}=28 \text { (boys and girls, age } 8-19 \text { ) swam } \\
\text { (breaststroke and an occasional length } \\
\text { of crawl) for } 33 \text { (children under } 121 / 2 \text { ) } \\
\text { or } 40 \text { minutes (older children) in water } \\
\text { @ } 20^{\circ} \mathrm{C} \text {, waiting on the wall every } 2 \\
\text { lengths just long enough to maintain an } \\
\mathrm{O}_{2} \text { consumption of } 30 \pm 11 / \mathrm{m} \text {. } \\
\text { Tre fell for all but the fattest swimmers } \\
\left(\mathrm{SCF} \text { thickness of } 11-18 \mathrm{~m} \times 10^{-2)} \text { in }\right. \\
20^{\circ} \mathrm{C} \text { water. The rate of fall in } \\
\text { sublingual temperatures decreased with } \\
\text { age and as overall fat thickness } \\
\text { increased. } \\
\text { Boys temp fall rate was faster than } \\
\text { girls and for younger children because } \\
\text { of lower fat thickness and high surface } \\
\text { area to mass ratio. }\end{array}$ & $2 \mathrm{a}$ \\
\hline 60 & $\begin{array}{l}\text { Smith RM, } \\
\text { Hanna JM }\end{array}$ & $\begin{array}{l}\text { Skinfolds and resting heat } \\
\text { loss in cold air and water: } \\
\text { temperature equivalence. } \\
\text { Smith RM, Hanna JM. J } \\
\text { Appl Physiol 1975; 39(1): } \\
\text { 93-102 }\end{array}$ & $\begin{array}{l}\mathrm{N}=14 \text { male subjects with a mean } \\
\text { skinfold (MSF) of } 10.23 \mathrm{~mm} \text { were } \\
\text { exposed to } 3 \text { hours of air and cold } \\
\text { water to determine heat loss (excluding } \\
\text { the head). Air temperatures were } 25 \text {, } \\
20 \text { and } 10^{\circ} \mathrm{C} \text {. Water experiments were } \\
\text { conducted @ subjects established Tcw } \\
\left(29-31^{\circ} \mathrm{C}\right) . \text { Body heat loss was a linear } \\
\text { function of the decrease in Ta in this } \\
\text { study. The range of Tcw is mainly a } \\
\text { result of the variability in the subjects' } \\
\text { subcutaneous fat thickness. Both MSF } \\
\text { and Surface area / mass ratio become } \\
\text { increasingly more important in cold } \\
\text { water. }\end{array}$ & $2 a$ \\
\hline 61 & $\begin{array}{l}\text { Smolander J, } \\
\text { Bar-or O, } \\
\text { Korhonen O, } \\
\text { Ilmarinen J, }\end{array}$ & $\begin{array}{l}\text { Thermoregulation during } \\
\text { rest and exercise in pre-and } \\
\text { early pubescent boys and } \\
\text { young men. Smolander J, } \\
\text { Bar-or O, Korhonen O, } \\
\text { Ilmarinen J. J Appl Physiol }\end{array}$ & $\begin{array}{l}\mathrm{N}=8 \text { boys (mean age } 11.8 \pm 0.5 \mathrm{yrs}) \\
\text { and } 11 \text { young adult men }(24.7 \pm 4.5 \mathrm{yrs}) \\
\text { participated in a thermoneutral }\left(21^{\circ} \mathrm{C}\right) \\
\text { test and a cold stress test }\left(\mathrm{Ta} @ 5^{\circ} \mathrm{C}\right) \\
\text { for } 60 \text { minutes at rest and during } \\
\text { exercise at } 30 \% \mathrm{VO}_{2} \max \text { (pre- }\end{array}$ & $2 \mathrm{a}$ \\
\hline
\end{tabular}




\begin{tabular}{|c|c|c|c|c|}
\hline & & 1992; 72: 1589-1594 & $\begin{array}{l}\text { determined). Boys had lower } \mathrm{BW} \text { and } \\
\text { significantly greater surface area-to- } \\
\text { mass ratio then men. There were no } \\
\text { significant differences in skinfold } \\
\text { thicknesses or in } \mathrm{VO}_{2} \text { max expressed in } \\
\mathrm{kg} / \mathrm{ml} / \mathrm{min} \text {. } \\
\text { Boys had lower skin temperatures at } \\
\text { the extremities and higher } \mathrm{VO}_{2} \\
\text { response to the cold than young men. } \\
\text { As a result the boys maintained their } \\
\text { core temperatures as effectively as the } \\
\text { adults. }\end{array}$ & \\
\hline 62 & $\begin{array}{l}\text { Strong LH, Gee } \\
\text { Gk, Goldman, } \\
\text { RF }\end{array}$ & $\begin{array}{l}\text { Metabolic and vasomotor } \\
\text { insulative responses } \\
\text { occurring on immersion in } \\
\text { cold water. Strong LH, Gee } \\
\text { Gk, Goldman, RF J Appl } \\
\text { Physiol 1985; 58(3): 964- } \\
977\end{array}$ & $\begin{array}{l}\text { This study followed changes in core } \\
\text { conductance from heat dissipation, via } \\
\text { vasodilation, to thermoneutrality and } \\
\text { from vasoconstriction to cold induced } \\
\text { vasodilation for subjects representing } \\
\text { different morphological types. } \\
\mathrm{N}=20 \text { healthy male volunteers (age } 17 \text { - } \\
28 \text { yrs), totally immersed, horizontally, } \\
\text { at rest in water } @ 28^{\circ} \mathrm{C} \text { and } 20^{\circ} \mathrm{C} \text { for } 1 \\
\text { hour per week for } 10 \text { weeks. Ten } \\
\text { subjects were also submerged in water } \\
@ 36,32 \text {, and } 24^{\circ} \mathrm{C} \text {. } \\
\text { Surface heat flow is greatest from the } \\
\text { head, thigh, abdomen, large chest } \\
\text { muscles. } \\
\text { Metabolic responses at } 35 \text { and } 32^{\circ} \mathrm{C} \\
\text { were essentially the same as pre- } \\
\text { emersion value. } \\
\text { In general metabolic rates increase as } \\
\text { Tw decreases until shivering } \\
\text { exhaustion is reached. "There is, } \\
\text { however, a marked individual variation } \\
\text { at Tw below } 32^{\circ} \mathrm{C} \\
\text { Tre fell in Tw below } 32^{\circ} \mathrm{C} \\
\text { Tre profiles are more variable among } \\
\text { subjects having average } \mathrm{BF} \text { ( } 12^{\circ} \% \leq \mathrm{BF} \\
\leq 19 \% \text { ) and body wt. ( } 70 \mathrm{~kg} \leq \mathrm{wt} \leq \\
90 \mathrm{~kg} \text { ) }\end{array}$ & $2 \mathrm{a}$ \\
\hline 63 & $\begin{array}{l}\text { Tikuisis P, } \\
\text { Jacobs I, Moroz }\end{array}$ & $\begin{array}{l}\text { Comparison of } \\
\text { thermoregulatory responses }\end{array}$ & $\begin{array}{l}\mathrm{N}=11 \text { women and } 14 \text { men were } \\
\text { immersed to the neck on a cot and lay }\end{array}$ & $2 a$ \\
\hline
\end{tabular}




\begin{tabular}{|c|c|c|c|c|}
\hline & $\begin{array}{l}\mathrm{D}, \text { Vallerand } \\
\mathrm{AL} \text {, and } \\
\text { Martineau L }\end{array}$ & $\begin{array}{l}\text { between man and women } \\
\text { immersed in cold water. } \\
\text { Tikuisis P, Jacobs I, Moroz } \\
\text { D, Vallerand AL, and } \\
\text { Martineau L. J Appl Physiol } \\
\text { 2000, 89: 1403-1411 }\end{array}$ & $\begin{array}{l}\text { quietly in Tw @ } 18 \pm 0.2^{\circ} \mathrm{C} \text { for } 90 \\
\text { minutes. The only significant gender } \\
\text { difference was the rate of change of } \\
\text { Tre. Men and women exhibited similar } \\
\text { changes in body cooling and } \\
\text { metabolism during cold water } \\
\text { immersion @ rest when subject } \\
\text { responses were corrected for body fat } \\
\text { and surface area/vol. Subjects of both } \\
\text { genders with the lowest SA/vol ratio } \\
\text { also responded with the lowest } \Delta \text { Tre / } \\
\Delta \text { t. }\end{array}$ & \\
\hline 64 & $\begin{array}{l}\text { Tipton B, Eglin } \\
\text { C, Gennser M, } \\
\text { Golden F. }\end{array}$ & $\begin{array}{l}\text { Immersion deaths and } \\
\text { deterioration in swimming } \\
\text { performance in cold water. } \\
\text { Tipton B, Eglin C, Gennser } \\
\text { M, Golden F. The Lancet. } \\
\text { 1999 354: 626-629 }\end{array}$ & $\begin{array}{l}\mathrm{N}=10 \text { swimmers, (age } 23-39 \text { and \%BF } \\
19.7) \text {, swam } 90 \text { minutes of breaststroke } \\
\text { at } \mathrm{Tw} 25^{\circ}, 18^{\circ} \mathrm{C} \text { and } 5 \text { swimmers at Tw } \\
10^{\circ} \mathrm{C} \text {. } \\
\text { Tre increased with self-paced } \\
\text { swimming in } 25^{\circ} \mathrm{C} \text { and were similar } @ \text {, } \\
18^{\circ} \mathrm{C} \text {. Swimming efficiency was } \\
\text { similar in } 25 \text { and } 18^{\circ} \mathrm{C} \text { and remained } \\
\text { constant throughout the swim. SE } \\
\text { declined in } 10^{\circ} \mathrm{C} \text { overtime (decrease in } \\
\text { stroke length and increase in stroke rate } \\
\text { and an increase in swimming angle). } \\
\text { After swimming at } 18 \text { and } 10^{\circ} \mathrm{C} \text {, grip } \\
\text { strength was significantly decreased } \\
\left(11 \% \text { and } 26^{\circ} \% \text { respectively). Arms }\right. \\
\text { were especially susceptible to cooling } \\
\text { with a correlation between swimming } \\
\text { failure and upper body skin fold } \\
\text { thickness. }\end{array}$ & $2 \mathrm{a}$ \\
\hline 65 & $\begin{array}{l}\text { Toner MM, } \\
\text { Sawka MN, } \\
\text { Foley ME, and } \\
\text { Pandolf KB }\end{array}$ & $\begin{array}{l}\text { Effects of body mass and } \\
\text { morphology on thermal } \\
\text { responses in water. Toner } \\
\text { MM, Sawka MN, Foley ME, } \\
\text { and Pandolf KB. J Appl } \\
\text { Physiol 1986, 521-525 }\end{array}$ & $\begin{array}{l}\mathrm{N}=10(5 \mathrm{LM} \text { and } 5 \mathrm{SM}) \text { with similar } \\
\mathrm{BF} \text { and } \mathrm{SF} \text { thicknesses were immersed } \\
\text { in a seated position to the neck at rest } \\
\text { and during exercise (M approximately } \\
550 \mathrm{w} \text { ) in Tw } @ 26^{\circ} \mathrm{C} \text { for } 1 \text { hour. At } \\
\text { rest Tre and Tsk were lower at hour in } \\
\text { both groups then at } 5 \text { and } 30 \text { minutes. } \\
\text { There was a significant relationship } \\
\text { between skinfolds and Tre during rest } \\
\text { in cold water. Ti values were higher } \\
\text { for LM compared to SM both prior to } \\
\text { and during immersion. There were no } \\
\text { significant differences between groups }\end{array}$ & $2 \mathrm{a}$ \\
\hline
\end{tabular}


ARC SAC Water Temperature and ARC Aquatic Courses Scientific Review

\begin{tabular}{|c|c|c|c|c|}
\hline & & & with exercise immersion. & \\
\hline 66 & $\begin{array}{l}\text { Toner MM, } \\
\text { Sawka MN, and } \\
\text { Pandolf KB }\end{array}$ & $\begin{array}{l}\text { Thermal responses during } \\
\text { arm and leg and combined } \\
\text { arm-leg exercise in water. } \\
\text { Toner MM, Sawka MN, and } \\
\text { Pandolf KB. J Appl Physiol: } \\
\text { Respirat Environ Exercise } \\
\text { Physiol, 1984. 56(5): } 1355- \\
1360 .\end{array}$ & $\begin{array}{l}\text { Thermal and metabolic responses were } \\
\text { examined during exposure in stirred } \\
\text { water @ } 20,26 \text {, and } 33^{\circ} \mathrm{C} . \mathrm{N}=8 \\
\text { males (age } 22.4 \pm 3.6 \text { and } \% \mathrm{BF} 13.4 \\
\pm 5.7 \text { ) were immersed to the neck and } \\
\text { exercised either arms only (A), legs } \\
\text { only (L) or arm-leg combined (AL) for } \\
45 \text { minutes. Each subject completed } \\
\text { each specific type exercise at both high } \\
(\approx 60 \% \text { ) and low ( } \approx 40 \% \text { ) intensities. At } \\
40 \% \text { intensity } \mathrm{M} \text { was significantly } \\
\text { higher in } 20 \text { and } 26^{\circ} \mathrm{C} \text { during A } \\
\text { compared with } 33^{\circ} \mathrm{C} \text { and higher only in } \\
20^{\circ} \mathrm{C} \text { for L and } \mathrm{AL} \text { exercise. In } 20^{\circ} \mathrm{C} \\
\text { Tre values declined steadily for all } \\
\text { types of exercise at } 40 \% \text { intensity. In } \\
26^{\circ} \mathrm{C} \text { Tre declined with } 40 \% \text { intensity } \\
\text { for A and AL exercise but remained } \\
\text { steady with L. During } 60 \% \text { intensity } \\
\text { exercise in } 26^{\circ} \mathrm{C} \text { and } 33^{\circ} \mathrm{C} \text {, Tre steadily } \\
\text { increased for L and AL. }\end{array}$ & $2 \mathrm{a}$ \\
\hline 67 & $\begin{array}{l}\text { USA } \\
\text { Swimming }\end{array}$ & $\begin{array}{l}2010 \text { USA Swimming Rules } \\
\text { and Regulations. USA } \\
\text { Swimming } 2010\end{array}$ & $\begin{array}{l}\text { Rule } 103.6 \text { - water temperature } \\
\text { between } 25-28 \text { degrees Celsius (77- } \\
82.4 \text { degrees Fahrenheit) shall be } \\
\text { maintained for competition. }\end{array}$ & 5 \\
\hline 68 & $\begin{array}{l}\text { Veicsteinas A, } \\
\text { Ferretti G, and } \\
\text { Rennie DW }\end{array}$ & $\begin{array}{l}\text { Superficial shell insulation } \\
\text { in resting and exercising } \\
\text { men in cold water. } \\
\text { Veicsteinas A, Ferretti G, } \\
\text { and Rennie DW. J Appl } \\
\text { Physiol: Respirat Environ } \\
\text { Exercise Physiol 1982; } \\
\text { 52(3): 1557-1564 }\end{array}$ & $\begin{array}{l}\mathrm{N}=9 \text { male subjects (BF ranging } \\
\text { between } 8.8 \text { and } 27.2 \%) \text { immersed, } \\
\text { head out, and rested for } 3 \text { hours in Tcw } \\
\left(28-33^{\circ} \mathrm{C}\right) \text { to study tissue insulation. } \\
\text { Immersion at rest in Tcw created an } \\
\text { initial large change in tissue insulation } \\
\text { which, after } 20 \text { minutes reach and } \\
\text { remained constant throughout. } \\
\text { Vasodilation occurred at Tw } 32-33^{\circ} \mathrm{C} \text {. } \\
\text { The results indicate that insulation } \\
\text { provided by unprofused skin and } \\
\text { subcutaneous fat accounts for only } 10- \\
15 \% \text { of Ti during rest in Tcw. The } \\
\text { remaining is most likely poorly } \\
\text { profused muscle. } \\
\text { Protocol } 2 \text { included mild exercise with } \\
\text { immersion. Tre increased } \approx 1^{\circ} \mathrm{C} \text { over } \\
\text { two hours of immersion }\end{array}$ & $2 \mathrm{a}$ \\
\hline
\end{tabular}


ARC SAC Water Temperature and ARC Aquatic Courses Scientific Review

\begin{tabular}{|c|c|c|c|c|}
\hline 69 & $\begin{array}{l}\text { Wade CE, } \\
\text { Dacanay SD, } \\
\text { and Smith RM }\end{array}$ & $\begin{array}{l}\text { Regional heat loss in resting } \\
\text { man during immersion in } \\
25.2^{\circ} \mathrm{C} \text { water. Wade CE, } \\
\text { Dacanay SD, and Smith RM. } \\
\text { Aviat space Environ Med } \\
\text { 1979; 50(6):590-593 }\end{array}$ & $\begin{array}{l}\mathrm{N}=5 \text { male subjects (age } 19-33 \text { and } \\
\% \mathrm{BF} \text { ranging from } 9.22 \text { to } 20.17 \text { ) were } \\
\text { immersed at rest, lying on a cot in Tw } \\
\text { @ } 25.2^{\circ} \mathrm{C} \text { for } 30 \text { minutes. Regional } \\
\text { heat flows were greatest in the neck, } \\
\text { head, and upper torso and total regional } \\
\text { heat loss was greatest from the torso. } \\
\text { Heat flow from the neck, head, and } \\
\text { torso was significantly correlated with } \\
\text { skinfold thickness. No significant } \\
\text { correlation was noted in the } \\
\text { extremities. Subcutaneous fat is the } \\
\text { most important factor in determination } \\
\text { of total body heat loss. The torso, head } \\
\text { and neck account for } 63 \% \text { of the heat } \\
\text { loss in } 25.2^{\circ} \mathrm{C} \text { water. }\end{array}$ & $2 a$ \\
\hline 70 & $\begin{array}{l}\text { Wade CE, } \\
\text { Veghte JH }\end{array}$ & $\begin{array}{l}\text { Thermographic evaluation of } \\
\text { the relative heat loss by area } \\
\text { in man after swimming. } \\
\text { Wade CE, Veghte JH. Aviat } \\
\text { Space Enviorn Med 1977; } \\
\text { 48(1): } 16-18\end{array}$ & $\begin{array}{l}\mathrm{N}=4 \text { competitive swimmers ages } 16-21 \\
\text { and \% BF ranging from } 8.3-27.2) \\
\text { underwent a } 5 \text { minute non swimming } \\
\text { immersion and a } 500 \mathrm{~m} \text { freestyle swim } \\
\text { at training pace }(60-75 \%) \text { in Tw @ } \\
23.5^{\circ} \mathrm{C} \text {. Subjects were scanned for } \\
\text { surface temperature prior to immersion } \\
\text { and after each of the aforementioned } \\
\text { conditions. Skinfold thickness was } \\
\text { found to correlate with the change in } \\
\text { Tsk. Radiograms of the subjects after } \\
\text { immersion showed the warmer areas } \\
\text { were the chest, groin, lower abdomen, } \\
\text { and lower neck. } \\
\text { After swimming, the warmer areas } \\
\text { were active muscle masses (trapezius, } \\
\text { deltoids, triceps, biceps brachi, and } \\
\text { pertorals). The legs were cooler. }\end{array}$ & $2 a$ \\
\hline 71 & $\begin{array}{l}\text { Wagner, JA, } \\
\text { Horvath SM }\end{array}$ & $\begin{array}{l}\text { Influences of age and gender } \\
\text { on human thermoregulatory } \\
\text { responses to cold exposures. } \\
\text { Wagner, JA, Horvath SM. J } \\
\text { Appl Physiol 1985; 58(1): } \\
\text { 180-186. }\end{array}$ & $\begin{array}{l}\mathrm{N}=10 \text { men and } 10 \text { women ages } 20-30 \\
\text { and } 10 \text { men and } 7 \text { women ages } 51-72 \\
\text { were exposed (with minimal clothing) } \\
\text { for } 2 \text { hours to Ta @ } 28,20,15 \text { and } \\
10^{\circ} \mathrm{C} \text { while resting in a semi-reclining } \\
\text { position. Results suggest that older } \\
\text { men may be more susceptible to cold } \\
\text { ambient than younger people since } \\
\text { they did not prevent a drop in Tre and }\end{array}$ & $\begin{array}{c}2 \mathrm{a} \\
2 \mathrm{aE}\end{array}$ \\
\hline
\end{tabular}




\begin{tabular}{|c|c|c|c|c|}
\hline & & & $\begin{array}{l}\text { had a lower initial Tre. Older women, } \\
\text { by virtue of higher } \% \text { BF and rapid } \\
\text { increase in metabolic rate did quite } \\
\text { well. } \\
\text { Changes in Tre and Tsk were greatly } \\
\text { dependent on the amount and } \\
\text { distribution of BF. }\end{array}$ & \\
\hline 72 & $\begin{array}{l}\text { Wagner, JA, } \\
\text { Horvath SM }\end{array}$ & $\begin{array}{l}\text { Cardiovascular reactions to } \\
\text { cold exposures differ with } \\
\text { age and gender. Wagner, } \\
\text { JA, Horvath SM. J Appl } \\
\text { Physiol 1985; 58(1): 187- } \\
192\end{array}$ & $\begin{array}{l}\mathrm{N}=10 \text { men and } 10 \text { women ages } 20-30 \\
\text { and } 10 \text { men and } 7 \text { women ages } 51-72 \\
\text { were exposed (with minimal clothing) } \\
\text { for } 2 \text { hours to Ta @ } 28,20,15 \text { and } \\
10^{\circ} \mathrm{C} \text { while resting in a semi-reclining } \\
\text { position. Heart rates }\left(\mathrm{f}_{\mathrm{c}} \text { ) decreased }\right. \\
\text { significantly over time during cold } \\
\text { exposure in men but not in women. } \\
\text { Regardless of age, men had higher } \\
\text { stroke volume (Qs) during the last hour } \\
\text { in all three colder environments when } \\
\text { compared to } 28^{\circ} \mathrm{C} \text {. Women did not. } \\
\text { During } 28^{\circ} \mathrm{C} \text { exposure, men had } \\
\text { significantly higher total arm blood } \\
\text { flows than women. } \\
\text { Younger subjects always had } \\
\text { significantly higher Qs than older } \\
\text { subjects. There were no significant } \\
\text { differences in blood pressures between } \\
\text { men and women but older subjects had } \\
\text { higher blood pressures than younger } \\
\text { subjects did. Older subjects had higher } \\
\text { forearm blood flows than younger } \\
\text { subjects for the first hour of exposure } \\
\text { in } 28^{\circ} \mathrm{C} \text {. The results of this study } \\
\text { indicate that cardiovascular } \\
\text { adjustments to moderate cold exposure } \\
\text { differ with both age and gender. }\end{array}$ & $\begin{array}{c}2 \mathrm{a} \\
2 \mathrm{aE}\end{array}$ \\
\hline 73 & $\begin{array}{l}\text { Wakabyashi H, } \\
\text { Kaneda K, } \\
\text { Okura M, and } \\
\text { Nomra T }\end{array}$ & $\begin{array}{l}\text { Insulation and body } \\
\text { temperature of prepubescent } \\
\text { children wearing a thermal } \\
\text { swimsuit during moderate- } \\
\text { intensity water exercise. } \\
\text { Wakabyashi H, Kaneda K, } \\
\text { Okura M, and Nomra T. J } \\
\text { Physiol Anthropol, } \\
\text { 2007:26(2): } 179-183\end{array}$ & $\begin{array}{l}\mathrm{N}=9 \text { prepubescent children ages } \\
11 \pm 0.7 \text { years ( } \% \mathrm{BF}, 15.1 \pm 4.9 \%) \text { were } \\
\text { immersed in Tw @ } 23^{\circ} \mathrm{C} \text { up to their } \\
\text { chest and pedaled on a cycle ergometer } \\
\text { for } 30 \text { minutes wearing a TSS or a } \\
\text { normal swim suit (NSS). The TSS } \\
\text { made of } 1.5 \mathrm{~mm} \text { thick neoprene covered } \\
\text { the thighs, trunk, upper arms and neck. } \\
\text { Submaximal exercise intensity was } \\
\text { based on a pre-test measured in an }\end{array}$ & $\begin{array}{c}2 \mathrm{a} \\
2 \mathrm{aE}\end{array}$ \\
\hline
\end{tabular}




\begin{tabular}{|c|c|c|c|c|}
\hline & & & $\begin{array}{l}\text { elementary swimming class }(\mathrm{HR}= \\
130-140 \mathrm{bpm}) \text {. } \\
\text { Tre was maintained slightly higher } \\
\text { using TSS than NSS. Total insulation } \\
\text { was higher with TSS. Tissue } \\
\text { insulation was related to \%BF in the } \\
\text { NSS condition and was lower in the } \\
\text { lowest fat subjects. Prepubescent } \\
\text { children with low body fat can } \\
\text { maintain Tre at the same level as obese } \\
\text { children by wearing a TSS. }\end{array}$ & \\
\hline 74 & $\begin{array}{l}\text { Wakabyashi } \mathrm{H} \text {, } \\
\text { Hanai A, } \\
\text { Yokoyama S, } \\
\text { and Nomra T }\end{array}$ & $\begin{array}{l}\text { Thermal insulation and body } \\
\text { temperature wearing a } \\
\text { thermalswim suit during } \\
\text { water immersion. } \\
\text { Wakabyashi H, Hanai A, } \\
\text { Yokoyama S, and Nomra T. } \\
\text { J Physiol Anthropol, } \\
\text { 2006:25(5): 331-338. }\end{array}$ & $\begin{array}{l}\text { This study compared healthy men } \\
\text { wearing either a normal swim suit or a } \\
\text { thermal swim suit immersed in water } \\
\text { @ } 26 \text { and } 29^{\circ} \mathrm{C} \text { for } 60 \text { minutes. } \\
\text { Tes was higher in both temperatures } \\
\text { for the thermal suit than the normal } \\
\text { swim suit. A thermal swim suit can } \\
\text { increase total insulation and reduce } \\
\text { heat loss from the skin. }\end{array}$ & $\begin{array}{c}2 \mathrm{a} \\
2 \mathrm{aE}\end{array}$ \\
\hline 75 & $\begin{array}{l}\text { Weihl AC, } \\
\text { Langworthy } \\
\text { HC, } \\
\text { Manalaysay } \\
\text { AR, Layton RP }\end{array}$ & $\begin{array}{l}\text { Metabolic responses of } \\
\text { resting man immersed in } \\
25.5^{\circ} \mathrm{C} \text { and } 33^{\circ} \mathrm{C} \text { water } \\
\text { Aviat Space Environ Med. } \\
198152(2) 88-91\end{array}$ & $\begin{array}{l}\mathrm{N}=16 \text { unprotected Navy divers (age } \\
\text { and } \% B F \text { NA) underwent total } \\
\text { immersion with a mask, sitting at } 3 \mathrm{M} \\
\text { in Tw } 25.5^{\circ} \text { and } 33^{\circ} \mathrm{C} \text {. There were } 3 \\
\text { total submersions of } 14 \text { minutes each. } \\
\text { Subjects were raised just long enough } \\
\text { to obtain a venous sample. } \\
\text { Tre declined in all subjects at } 25.5^{\circ} \mathrm{C} \text {. } \\
\text { Exposure to } 25^{\circ} \mathrm{C} \text { resulted in } \\
\text { uncontrollable shivering by the } 42^{\text {nd }} \\
\text { minutes. In } 33^{\circ} \mathrm{C} \text { there was no } \\
\text { significant difference in Tre. }\end{array}$ & $2 a$ \\
\hline
\end{tabular}




\begin{tabular}{|c|c|}
\hline $\begin{array}{l}\text { Level of } \\
\text { Evidence }\end{array}$ & $\begin{array}{c}\text { Definitions } \\
\text { (See manuscript for full details) }\end{array}$ \\
\hline Level 1a & $\begin{array}{l}\text { Population based studies, randomized prospective studies or meta-analyses of multiple studies } \\
\text { with substantial effects }\end{array}$ \\
\hline Level 1b & $\begin{array}{l}\text { Large non-population based epidemiological studies or randomized prospective studies with } \\
\text { smaller or less significant effects }\end{array}$ \\
\hline Level 2a & Prospective, controlled, non-randomized, cohort or case-control studies \\
\hline Level 2b & Historic, non-randomized, cohort or case-control studies \\
\hline Level 2c & Case series: convenience sample epidemiological studies \\
\hline Level 3a & Large observational studies \\
\hline Level 3b & Smaller observational studies \\
\hline Level 4 & Animal studies or mechanical model studies \\
\hline Level 5 & $\begin{array}{l}\text { Peer-reviewed, state of the art articles, review articles, organizational statements or guidelines, } \\
\text { editorials, or consensus statements }\end{array}$ \\
\hline Level 6 & $\begin{array}{l}\text { Non-peer reviewed published opinions, such as textbook statements, official organizational } \\
\text { publications, guidelines and policy statements which are not peer reviewed and consensus } \\
\text { statements }\end{array}$ \\
\hline Level 7 & $\begin{array}{l}\text { Rational conjecture (common sense); common practices accepted before evidence-based } \\
\text { guidelines }\end{array}$ \\
\hline Level 1-6E & $\begin{array}{l}\text { Extrapolations from existing data collected for other purposes, theoretical analyses which is on- } \\
\text { point with question being asked. Modifier E applied because extrapolated but ranked based on } \\
\text { type of study. }\end{array}$ \\
\hline
\end{tabular}




\section{ARC SAC SCIENTIFIC REVIEW \\ Appropriate water temperatures in which to conduct American Red Cross Aquatic Instructional programs}

Scientific Advisory Council

\section{Literature Review with Temperature and Testing Data}

\begin{tabular}{|c|c|c|c|c|c|c|c|c|c|}
\hline LOE & Ref \# & Head in & Head out & $\begin{array}{l}\text { Age } \\
\text { range }\end{array}$ & $\begin{array}{l}\text { Immersion } \\
\text { time }\end{array}$ & $\begin{array}{l}\text { Exercise } \\
\text { intensity }\end{array}$ & $\% \mathrm{BF}$ & $\begin{array}{l}\text { Temp } \\
\text { range }\end{array}$ & 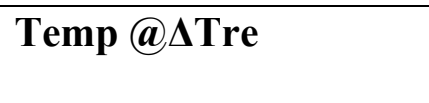 \\
\hline 2 & 9 & & To the neck & & $60 \mathrm{~min}$ & $\begin{array}{l}\mathrm{MR}+ \\
60 \mathrm{kcal}\end{array}$ & $\begin{array}{l}\text { SFT } \\
\text { Lean } \\
2.8 \pm 0.2 \\
\text { Normal } \\
4.5 \pm 0.2 \\
\text { Obese } \\
7.7 \pm .3\end{array}$ & $\begin{array}{l}15,20,25 \\
30,35^{\circ} \mathrm{C}\end{array}$ & $\begin{array}{l}\downarrow \text { with Tw less than } 30^{\circ} \mathrm{C} \\
\text { regardless of rest or } \\
\text { exercise } \\
\text { Gradual } \downarrow \text { in Tre after the } \\
\text { first } 20 \mathrm{~min}\end{array}$ \\
\hline 2 & 11 & swimming & & $\begin{array}{l}18-29 \\
\text { Mean } \\
21.13\end{array}$ & $20 \mathrm{~min}$ & Submax & $\begin{array}{l}4.6-10.4 \\
\text { Mean } 7.7 \%\end{array}$ & $\begin{array}{l}17.4,26.8, \\
33.1\end{array}$ & $\begin{array}{l}\uparrow \text { Tre in all temperatures } \\
\downarrow \text { Tre during recovery @ } \\
17.4 \text { Tre was lower than } \\
\text { control }\end{array}$ \\
\hline 2 & 12 & & $\begin{array}{l}\text { Immersed to } \\
\text { the chin } \\
\text { Semi- } \\
\text { recumbent }\end{array}$ & 26 & $60 \mathrm{~min}$ & NA & $\begin{array}{l}15.5 \pm 8.1 \% \\
\mathrm{SCF} \\
5.4 \pm 1.4\end{array}$ & $\begin{array}{l}24,26,28 \\
30,32,34 \\
36,37^{\circ} \mathrm{C}\end{array}$ & $\begin{array}{l}\text { In } \mathrm{Tw} \leq 35^{\circ} \mathrm{C}, \mathrm{Tc} \text { were } \\
\text { below control values at } \\
60 \text { min of immersion. } \\
\uparrow \mathrm{Tre} \text { in } 24,26,28^{\circ} \mathrm{C} \\
\text { over the first } 10-20 \\
\text { minutes. } \\
\uparrow \mathrm{V}_{2} \text { occurred in } 30^{\circ} \mathrm{C} \\
@ 40 \text { minutes or less. } \\
\text { For } 60 \text { minutes Tw } \\
\text { would have to be } 32^{\circ} \mathrm{C} \\
\text { to prevent shivering } \\
\uparrow T r e @ 36 \& 37^{\circ} \mathrm{C}\end{array}$ \\
\hline $\begin{array}{l}2 \\
2 \mathrm{E}\end{array}$ & 13 & & $\begin{array}{l}\text { Head out } \\
\text { nearly }\end{array}$ & $27 \pm 5.8$ & 60 minutes & $\begin{array}{l}\text { Submax } \\
\text { light work }\end{array}$ & $14 \% \mathrm{BF}$ & $\begin{array}{l}24,26,28, \\
31,31\end{array}$ & $\begin{array}{l}\uparrow \text { Tre @ } 28-32^{\circ} \mathrm{C} \text { w/high } \\
\text { work loads }\end{array}$ \\
\hline
\end{tabular}


ARC SAC Water Temperature and ARC Aquatic Courses Scientific Review

\begin{tabular}{|c|c|c|c|c|c|c|c|c|c|}
\hline $\begin{array}{l}\text { TA } \\
27 \pm 1.6^{\circ} \mathrm{C} \\
\text { Humidity } \\
55 \pm 8 \%\end{array}$ & & & horizontal & & & load & & $32^{\circ} \mathrm{C}$ & $\begin{array}{l}\downarrow \mathrm{T} \text {-ear } @ \mathrm{Tw}<32^{\circ} \mathrm{C} \\
\text { with low workload } \\
@ 60 \text { min increment in } \\
\text { temp same as resting } \\
\text { Temp to prevent } \Delta \mathrm{Tre} \\
\text { for light workload is } \\
34^{\circ} \mathrm{C} \text {. For heavy } \\
\text { workload, } 29^{\circ} \mathrm{C}\end{array}$ \\
\hline $\mathrm{LOE}$ & Ref \# & Head in & Head out & $\begin{array}{l}\text { Age } \\
\text { range }\end{array}$ & $\begin{array}{l}\text { Immersion } \\
\text { time }\end{array}$ & $\begin{array}{l}\text { Exercise } \\
\text { intensity }\end{array}$ & $\% \mathrm{BF}$ & $\begin{array}{l}\text { Temp } \\
\text { range }\end{array}$ & 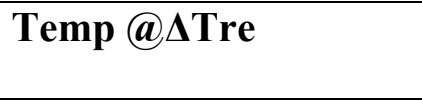 \\
\hline \multirow[t]{5}{*}{$\begin{array}{l}2 \\
\text { Ta } 25^{\circ} \mathrm{C}, \\
\text { RH } 65 \%\end{array}$} & 20 & $\begin{array}{l}\text { Swim } \\
\text { Breast } \\
\text { stroke } \\
\text { Constant } \\
\text { speed }\end{array}$ & & $\begin{array}{l}19.8 \pm 0.9 \\
\text { years }\end{array}$ & $120 \mathrm{~min}$ & $\begin{array}{l}50 \pm 5 \% \max \\
@ 23^{\circ} \mathrm{C} \\
43 \pm 6 \% @ \\
28^{\circ} \mathrm{C} \\
42 \pm 4 \% @ \\
33^{\circ} \mathrm{C}\end{array}$ & $13.2 \pm 3.4 \%$ & $\begin{array}{l}23,28 \\
33^{\circ} \mathrm{C}\end{array}$ & $\begin{array}{l}\text { Tre steadily declined } \\
\text { and was significant after } \\
20 \text { minutes } @ 23^{\circ} \mathrm{C} \text { and } \\
28^{\circ} \mathrm{C} \\
\text { No change at } 33^{\circ} \mathrm{C}\end{array}$ \\
\hline & 21 & $\begin{array}{l}\text { Swim breast } \\
\text { stroke }\end{array}$ & & $\begin{array}{l}23-41 \\
\text { years }\end{array}$ & $60 \mathrm{~min}$ & $65 \% \max$ & NA & $\begin{array}{l}21,27 \\
33^{\circ} \mathrm{C}\end{array}$ & $\begin{array}{l}\downarrow \text { Tre @2 } 21^{\circ} \mathrm{C} \\
\uparrow \text { significantly@33 } \\
\text { And to a smaller extent } \\
\text { in } 27^{\circ} \mathrm{C}\end{array}$ \\
\hline & 23 & & $\begin{array}{l}\text { Sitting } \\
\text { Ist thoracic } \\
\text { vertebrae }\end{array}$ & $\begin{array}{l}18-30 \\
40-55\end{array}$ & $\begin{array}{l}40 \text { min or } \\
\text { when Tes } \downarrow \\
\text { to } 36.5^{\circ} \mathrm{C}\end{array}$ & NA & $\begin{array}{l}10.9 \pm 2.9 \% \\
13.7 \pm 8.4 \%\end{array}$ & $20^{\circ} \mathrm{C}$ & $\begin{array}{l}\text { Tes } \downarrow \text { in both age groups } \\
\text { at } 20^{\circ} \mathrm{C} \text { at rest }\end{array}$ \\
\hline & 24 & & $\begin{array}{l}\text { Ist thoracic } \\
\text { vertebrae }\end{array}$ & $20-35$ & $90 \mathrm{~min}$ & NA & $\begin{array}{l}\mathrm{LF}=9-12 \% \\
\mathrm{HF}=18- \\
22 \%\end{array}$ & $\begin{array}{l}18-22- \\
26^{\circ} \mathrm{C}\end{array}$ & $\begin{array}{l}\text { Tre declined as a } \\
\text { function of time and } \\
\text { were similar for all } \\
\text { subjects at each time } \\
\text { point over the } 90 \\
\text { minutes. }\end{array}$ \\
\hline & 25 & & $\begin{array}{l}\text { Sitting } \\
\text { Ist thoracic } \\
\text { vertebrae }\end{array}$ & NA & $120 \mathrm{~min}$ & NA & $\begin{array}{l}14.5 \pm 4.1 \% \\
(\mathrm{LM}) \\
16.5 \pm 3.5 \% \\
(\mathrm{SM})\end{array}$ & $18^{\circ} \mathrm{C}$ & $\begin{array}{l}\text { Tre declined for all } \\
\text { subjects as a function of } \\
\text { time }\end{array}$ \\
\hline
\end{tabular}


ARC SAC Water Temperature and ARC Aquatic Courses Scientific Review

\begin{tabular}{|c|c|c|c|c|c|c|c|c|c|}
\hline 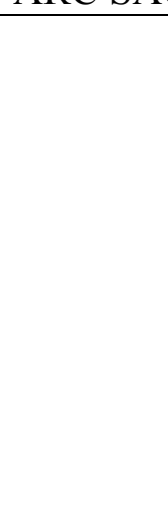 & 30 & $\begin{array}{l}\text { Swimming } \\
\text { Vs } \\
\text { running }\end{array}$ & & $\begin{array}{l}14-29 \\
\text { mean } \\
21.4 \pm 7.3\end{array}$ & $20 \mathrm{~min}$ & $50 \% \max$ & $8.2 \pm 3.2 \%$ & $\begin{array}{l}18,26 \\
34^{\circ} \mathrm{C}\end{array}$ & $\begin{array}{l}\uparrow \text { Tes in } 26 \text { \& } 34 \text { with } \\
\text { max } \\
\uparrow T e s \text { in } 26 \text { \& } 34 \text { with } \\
\text { submax } \\
\text { The leanest subject } \\
\text { (3.8\%BF) could not } \\
\text { sustain Tes w/submax } \\
\text { swimming in } 26 \text { or } 18^{\circ} \mathrm{C} \\
\text { Subject with } 6.2 \% \mathrm{BF} \\
\text { maintained Tes in } 26^{\circ} \mathrm{C}\end{array}$ \\
\hline LOE & Ref \# & Head in & Head out & $\begin{array}{l}\text { Age } \\
\text { range }\end{array}$ & $\begin{array}{l}\text { Immersion } \\
\text { time }\end{array}$ & $\begin{array}{l}\text { Exercise } \\
\text { intensity }\end{array}$ & $\% \mathrm{BF}$ & $\begin{array}{l}\text { Temp } \\
\text { range }\end{array}$ & 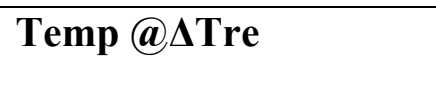 \\
\hline 2 & 31 & $\begin{array}{l}\text { Swim breast } \\
\text { stroke }\end{array}$ & $\mathbf{N A}$ & & $60 \mathrm{~min}$ & $65 \% \max$ & NA & $\begin{array}{l}21,27, \\
33^{\circ} \mathrm{C}\end{array}$ & $\begin{array}{l}\text { 个Tre and Tes@27\& } \\
33^{\circ} \mathrm{C} \\
\downarrow \text { Tre@ } 21^{\circ} \mathrm{C}\end{array}$ \\
\hline $\begin{array}{l}2 \\
2 \mathrm{E}\end{array}$ & 32 & & $\begin{array}{l}\text { Immersed to } \\
\text { the neck }\end{array}$ & $\begin{array}{l}21-32 \\
\text { Mean } \\
26.8 \\
\end{array}$ & $30 \mathrm{~min}$ & $\begin{array}{l}60 \% \max \\
\text { cycling }\end{array}$ & $\begin{array}{l}14.8 \pm \\
5.6 \%\end{array}$ & $\begin{array}{l}21,25 \\
29^{\circ} \mathrm{C}\end{array}$ & $\begin{array}{l}\uparrow T r e @ 29^{\circ} \mathrm{C} \\
\text { Similar@25ㄷ } \\
\downarrow @ 21^{\circ} \mathrm{C}\end{array}$ \\
\hline $\begin{array}{l}2 \\
2 \mathrm{E} \\
\text { Ta } 30^{\circ} \mathrm{C} \\
\text { RH } 60 \%\end{array}$ & 33 & & $\begin{array}{l}\text { To the neck } \\
\text { water } \\
\text { circulated }\end{array}$ & $23-36$ & $120 \mathrm{~min}$ & NA & $15.3 \pm 1.2 \%$ & & $\begin{array}{l}\text { Tcw } 32 \pm 0.4^{\circ} \mathrm{C} \\
\text { Tes } \downarrow \text { at a faster rate in } \\
\text { the first hour than in the } \\
\text { second }\end{array}$ \\
\hline $\begin{array}{l}2 \\
2 \mathrm{E} \\
\operatorname{Ta} 25^{\circ} \mathrm{C}\end{array}$ & 36 & & $\begin{array}{l}\text { To the } \\
\text { shoulders }\end{array}$ & $19-26$ & $20 \mathrm{~min}$ & $\begin{array}{l}\text { Rowing } \\
\text { ergometer } \\
\text { A standard } \\
\text { rate? }\end{array}$ & NA & $\begin{array}{l}5,15,25, \\
35,37^{\circ} \mathrm{C}\end{array}$ & $\begin{array}{l}\uparrow T r e @ 35^{\circ} \mathrm{C} \\
\text { Slight } \downarrow \text { with work in } \\
\mathrm{Tw}<25^{\circ} \mathrm{C}\end{array}$ \\
\hline $\begin{array}{l}2 \\
2 \mathrm{E} \\
\mathrm{Ta} 24- \\
26^{\circ} \mathrm{C}\end{array}$ & 38 & & To the neck & $\begin{array}{l}18-22 \\
22-31\end{array}$ & $60 \mathrm{~min}$ & NA & $\begin{array}{l}21-24 \% \mathrm{BF} \\
29-41 \% \mathrm{BF}\end{array}$ & $20^{\circ} \mathrm{C}$ & $\begin{array}{l}\text { Tre for obese rose over } \\
\text { the } 1^{\text {st }} 15 \text { min and then } \\
\text { slowly dropped } \\
\text { Tre for Lean } \downarrow 1.4^{\circ} \mathrm{C}\end{array}$ \\
\hline
\end{tabular}


ARC SAC Water Temperature and ARC Aquatic Courses Scientific Review

\begin{tabular}{|c|c|c|c|c|c|c|c|c|c|}
\hline & & & & & & & & & $\begin{array}{l}\text { compared to } .4^{\circ} \mathrm{C} \text { for } \\
\text { obese }\end{array}$ \\
\hline $\begin{array}{l}2 \\
2 \mathrm{E}\end{array}$ & 41 & & $\begin{array}{l}\text { Shoulder } \\
\text { immersion }\end{array}$ & 25 & $\begin{array}{l}\text { Up to } 135 \\
\text { min }\end{array}$ & $35 \% \max$ & $16 \%$ & $\begin{array}{l}15,25 \\
35^{\circ} \mathrm{C}\end{array}$ & $\downarrow$ Tre@25ㄷ \\
\hline $\begin{array}{l}2 \\
2 \mathrm{E}\end{array}$ & 42 & & $\begin{array}{l}1^{\text {st }} \text { thoracic } \\
\text { vertebrae }\end{array}$ & $19-29$ & $60 \mathrm{~min}$ & NA & $\begin{array}{l}\text { Men } \\
15-18 \% \\
\text { Women } \\
24-27 \%\end{array}$ & $\begin{array}{l}20,24, \\
28^{\circ} \mathrm{C}\end{array}$ & $\begin{array}{l}\text { Men } 15-18 \% \text { BF }- \text { Tre } \\
\text { remained constant for } \\
10-20 \text { min } \\
\text { For women } 24-27 \% \text {, Tre } \\
\text { remained constant for } 20 \\
\text { min then declined in all } \\
\text { Tws }\end{array}$ \\
\hline LOE & Ref \# & Head in & Head out & $\begin{array}{l}\text { Age } \\
\text { range }\end{array}$ & $\begin{array}{l}\text { Immersion } \\
\text { time }\end{array}$ & $\begin{array}{l}\text { Exercise } \\
\text { intensity }\end{array}$ & $\% \mathrm{BF}$ & $\begin{array}{l}\text { Temp } \\
\text { range }\end{array}$ & 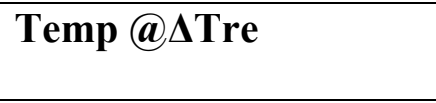 \\
\hline $\begin{array}{l}2 \\
2 \mathrm{E}\end{array}$ & 43 & & $\begin{array}{l}1^{\text {st }} \text { thoracic } \\
\text { vertebrae }\end{array}$ & $19-29$ & $60 \mathrm{~min}$ & $\begin{array}{l}\begin{array}{l}\text { Arm/leg } \\
\text { ergometer }\end{array} \\
20,36,49 \% \\
\text { for men } \\
27,48 \text { and } \\
66 \% \text { for } \\
\text { women }\end{array}$ & $\begin{array}{l}8-18 \% \\
15-29 \%\end{array}$ & $20,28^{\circ} \mathrm{C}$ & $\begin{array}{l}\text { For women Tre } \downarrow \text { at rest } \\
\text { and Level I intensity @ } \\
28^{\circ} \mathrm{C} \\
\text { Tre } \uparrow \text { slightly for both } \\
\text { level II and III ( } 48-66 \% \\
\text { max) } \\
\text { In males Tre } \downarrow \text { in } 20^{\circ} \mathrm{C} \text { at } \\
\text { all exercise intensities } \\
\text { Tre } \downarrow \text { in } 28^{\circ} \mathrm{C} \text { for level I } \\
\text { and II exercise but } \uparrow \text { with } \\
49 \% \text { intensity } \\
\text { For women Tre }\end{array}$ \\
\hline $\begin{array}{l}2 \\
2 \mathrm{E}\end{array}$ & 44 & & To the neck & $18-22$ & $30 \mathrm{~min}$ & $60 \% \max$ & $\begin{array}{l}\text { Runners } \\
7.4 \pm 0.9 \% \\
\text { Swimmers } \\
9.9 \pm 1.2 \%\end{array}$ & $\begin{array}{l}20,25,30, \\
35^{\circ} \mathrm{C}\end{array}$ & $\begin{array}{l}\text { Runners } \downarrow \text { Tre in } 20^{\circ} \mathrm{C} \\
\text { Swimmers } \uparrow \text { Tre in } 20^{\circ} \mathrm{C} \\
\text { (non significant) } \\
\text { Tre } \uparrow \text { in all Tw above } \\
20^{\circ} \mathrm{C}\end{array}$ \\
\hline
\end{tabular}


ARC SAC Water Temperature and ARC Aquatic Courses Scientific Review

\begin{tabular}{|c|c|c|c|c|c|c|c|c|c|}
\hline $\begin{array}{l}2 \\
2 \mathrm{E}\end{array}$ & 45 & $\begin{array}{l}\text { Submerged } \\
\text { with } \\
\text { SCUBA }\end{array}$ & & \begin{tabular}{|l|}
$23-42$ \\
$(32.2)$
\end{tabular} & $\begin{array}{l}5 \text { min rest, } 5 \\
\text { min work } \\
\text { followed by } \\
3 \text { min rest } \\
\text { At each work } \\
\text { load. } \approx 30 \\
\text { min }\end{array}$ & $\begin{array}{l}\text { Light } \\
\text { Moderate } \\
\text { Heavy } \\
(75 \% \text { max })\end{array}$ & $18.0 \pm 2.3$ & $\begin{array}{l}16,22 \\
30^{\circ} \mathrm{C}\end{array}$ & $\begin{array}{l}\text { Tre was maintained with } \\
\text { all workloads at all } \\
\text { temperatures during the } \\
5 \text { minute exercise bouts }\end{array}$ \\
\hline 2 & 47 & $\begin{array}{l}\text { Swam } \\
\text { breast } \\
\text { stroke }\end{array}$ & & $24-26$ & $20 \mathrm{~min}$ & $\begin{array}{l}40,70 \\
100 \% \max \end{array}$ & $\begin{array}{l}12.4 \\
8.7 \\
7.4\end{array}$ & $\begin{array}{l}18,26 \\
33^{\circ} \mathrm{C}\end{array}$ & $\begin{array}{l}\text { (@) } 40 \% \downarrow \text { Tre in } 18 \& \\
26^{\circ} \mathrm{C} \\
\text { @ } 70 \% \downarrow \text { Tre with } 2 \\
\text { leanest subjects in } 18^{\circ} \mathrm{C} \\
@ 70 \% \uparrow \text { Tre in } 26 \& \\
33^{\circ} \mathrm{C}\end{array}$ \\
\hline 2 & 48 & $\begin{array}{l}\text { Swam } \\
\text { breast stroke }\end{array}$ & $23-32$ & & $60 \mathrm{~min}$ & $\begin{array}{l}\text { Moderate } \approx \\
49 \% \\
\approx 60 \%\end{array}$ & $\begin{array}{l}\text { SFT }=8.3- \\
9.4\end{array}$ & $30 \& 33^{\circ} \mathrm{C}$ & $\begin{array}{l}\text { Tre } \uparrow \text { at both workloads } \\
\text { in both temperatures }\end{array}$ \\
\hline LOE & Ref \# & Head in & Head out & \begin{tabular}{|l|}
$\begin{array}{l}\text { Age } \\
\text { range }\end{array}$ \\
\end{tabular} & $\begin{array}{l}\text { Immersion } \\
\text { time }\end{array}$ & $\begin{array}{l}\text { Exercise } \\
\text { intensity }\end{array}$ & $\% \mathrm{BF}$ & $\begin{array}{l}\text { Temp } \\
\text { range }\end{array}$ & 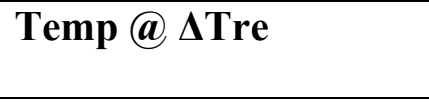 \\
\hline $\begin{array}{l}2 \\
2 \mathrm{E}\end{array}$ & 50 & & Head out & $\begin{array}{l}\text { Medical } \\
\text { students }\end{array}$ & $15 \mathrm{~min}$ & $\begin{array}{l}\text { Bicycle } \\
\text { ergometer } \\
33 \%, 66 \% \\
100 \%\end{array}$ & NA & $20-40^{\circ} \mathrm{C}$ & $\begin{array}{l}\text { Hyperthermia in } \mathrm{Tw} \geq \\
30^{\circ} \mathrm{C} \text { at } \approx 50 \% \text { intensity } \\
\text { At } \approx 50 \% \text { intensity, } \\
\text { thermal balance was } \\
\text { maintained }(+) \text { in } 20^{\circ} \mathrm{C}\end{array}$ \\
\hline 2 & 56 & $\begin{array}{l}\text { Swam } \\
\text { freestyle }\end{array}$ & & $20-24$ & $60 \mathrm{~min}$ & Various & NA & $\begin{array}{l}21,29 \\
33.5^{\circ} \mathrm{C}\end{array}$ & $\begin{array}{l}\text { Tre of the slowest } \\
\text { swimmers } \downarrow \text { in } 21^{\circ} \mathrm{C} \\
\text { Tre of fastest swimmers } \\
\uparrow @ 21^{\circ} \mathrm{C} \\
\text { Tre } \uparrow \text { in } 29^{\circ} \mathrm{C} \\
\text { Swimmers became } \\
\text { distressed in } 33.5^{\circ} \mathrm{C}\end{array}$ \\
\hline $\begin{array}{l}2 \\
2 \mathrm{E} \\
\end{array}$ & 57 & & $\begin{array}{l}\text { To the neck } \\
\text { In stirred }\end{array}$ & $\begin{array}{l}24-50 \\
\text { Mean }\end{array}$ & $60 \mathrm{~min}$ & $\begin{array}{l}\text { LE } \\
20,30 \text { and }\end{array}$ & $\begin{array}{l}18-23 \\
\text { Mean } \\
\end{array}$ & $\begin{array}{l}31.2,28.8 \\
34,36^{\circ} \mathrm{C} \\
\end{array}$ & $\begin{array}{l}\text { Tre } \uparrow \text { at all temperatures } \\
\text { with all workloads }\end{array}$ \\
\hline
\end{tabular}


ARC SAC Water Temperature and ARC Aquatic Courses Scientific Review

\begin{tabular}{|c|c|c|c|c|c|c|c|c|c|}
\hline $\begin{array}{l}\text { Ta } 25^{\circ} \mathrm{C} \\
\text { RH } 56 \%\end{array}$ & & & water & $43 \pm 4.1$ & & $40 \% \max$ & $19.9 \pm 1.2 \%$ & & $\begin{array}{l}20 \% \text { intensity was } \\
\text { enough to maintain } \\
\text { Thermal balance in Btn }\end{array}$ \\
\hline $\begin{array}{l}2 \\
2 \mathrm{E}\end{array}$ & 58 & & $\begin{array}{l}\text { To the } \\
\text { xyphoid }\end{array}$ & $18-20$ & $60 \mathrm{~min}$ & $\begin{array}{l}\text { Walking } \\
50 \% \max \end{array}$ & $\begin{array}{l}7.0-15.0 \\
\text { Mean } \\
11.1 \pm 2.5 \%\end{array}$ & $\begin{array}{l}25,30 \\
35^{\circ} \mathrm{C}\end{array}$ & $\begin{array}{l}\text { Tre } \uparrow \text { over the } 60 \mathrm{~min} \text { at } \\
\text { all temperatures }\end{array}$ \\
\hline 2 & 59 & $\begin{array}{l}\text { Swam } \\
\text { breast } \\
\text { stroke and } \\
\text { some } \\
\text { freestyle }\end{array}$ & & $8-20$ & $\begin{array}{l}33 \mathrm{~min} \\
40 \mathrm{~min}\end{array}$ & $\begin{array}{l}\text { Easy to } \\
\text { moderate } \\
30 \pm 11 / \mathrm{m}\end{array}$ & $\begin{array}{l}\text { SFT } \\
\text { Between } \\
5.8 \text { and } 19.2 \\
\mathrm{~m} \mathrm{X} 10^{-2}\end{array}$ & $20^{\circ} \mathrm{C}$ & $\begin{array}{l}\text { Tre } \downarrow \text { in all cases } \\
\text { Non significant } \\
\text { decreases with } \\
\text { individuals whose SFT } \\
\text { was btw } 11-18 \\
\end{array}$ \\
\hline $\begin{array}{l}2 \\
\text { Ta } 23- \\
24^{\circ} \mathrm{C}\end{array}$ & 62 & $\begin{array}{l}\text { Totally } \\
\text { immersed } \\
\text { In still water }\end{array}$ & & $17-28$ & $60 \mathrm{~min}$ & NA & $\begin{array}{l}23 \% \\
11-15 \% \\
7-9 \%\end{array}$ & $\begin{array}{l}20,24,28 \\
32,36^{\circ} \mathrm{C}\end{array}$ & $\begin{array}{l}\text { Tre between groups at } \\
20^{\circ} \mathrm{C} \text { differed by as } \\
\text { much as } 1^{\circ} \mathrm{C} \\
\text { Tre the same @ } 32 \& \\
35^{\circ} \mathrm{C} \text { and } \downarrow \text { in } \mathrm{Tw} \text { below } \\
32^{\circ} \mathrm{C} \text { except for the } \\
\text { heaviest subjects }\end{array}$ \\
\hline LOE & Ref \# & Head in & Head out & \begin{tabular}{|l|} 
Age \\
range
\end{tabular} & $\begin{array}{l}\text { Immersion } \\
\text { time }\end{array}$ & $\begin{array}{l}\text { Exercise } \\
\text { intensity }\end{array}$ & $\% \mathrm{BF}$ & $\begin{array}{l}\text { Temp } \\
\text { range }\end{array}$ & 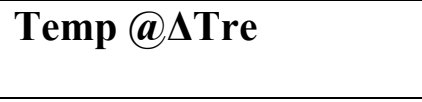 \\
\hline 2 & 64 & $\begin{array}{l}\text { Swimming } \\
\text { breast } \\
\text { stroke }\end{array}$ & & $\begin{array}{l}23-39 \\
\text { Mean } 30\end{array}$ & $90 \mathrm{~min}$ & Self paced & $\begin{array}{l}10.6-26.8 \% \\
\text { Mean } \\
19.7 \%\end{array}$ & $18 \& 25^{\circ} \mathrm{C}$ & $\begin{array}{l}\text { Tre } \uparrow @ 25^{\circ} \mathrm{C} \\
\text { Tre nearly the same @ } \\
18^{\circ} \mathrm{C}\end{array}$ \\
\hline $\begin{array}{l}2 \\
2 \mathrm{E}\end{array}$ & 66 & & To the neck & $22.4 \pm 3.6$ & $45 \mathrm{~min}$ & $\begin{array}{l}\mathrm{A}, \mathrm{AL}, \mathrm{L} \\
\approx 40 \% \quad \& \\
\approx 60 \%\end{array}$ & $13.4 \pm 5.7 \%$ & $\begin{array}{l}20,26, \\
33^{\circ} \mathrm{C}\end{array}$ & $\begin{array}{l}\downarrow \text { Tre in } 20^{\circ} \mathrm{C} \text { low } \\
\text { intensity exercise } \\
\downarrow \text { Tre in } 26^{\circ} \mathrm{C} \text { with low } \\
\text { intensity } \approx 40 \% \text { exercise } \\
\text { except } \mathrm{L} \\
\uparrow T r e \text { in } 26^{\circ} \mathrm{C} \& 33^{\circ} \mathrm{C} \\
\text { for high intensity } \approx 60 \% \\
\mathrm{AL} \text { and } \mathrm{L}\end{array}$ \\
\hline 2 & 74 & Total & & Navy & $45 \mathrm{~min}$ & $\mathrm{NA}$ & NA & $25.5^{\circ} \mathrm{C}$ and & Tre $\downarrow$ in all subjects @ \\
\hline
\end{tabular}


ARC SAC Water Temperature and ARC Aquatic Courses Scientific Review

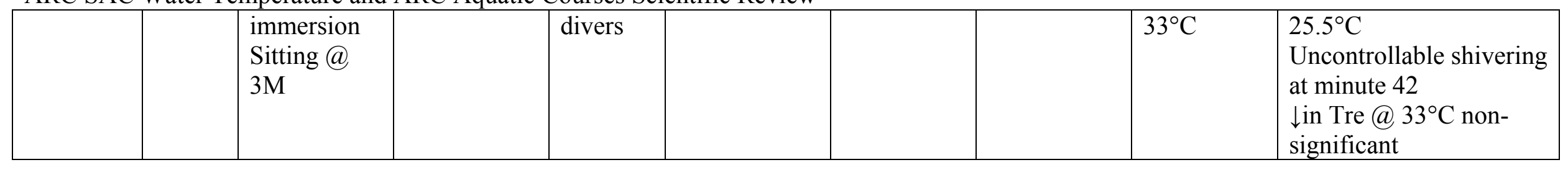

